PPS-3-288 出血性小腸 Gatrointestinal stromal tumor (GIST) を併発 した von Recklinghausen（vR）病の 1 例

菅原浩, 海法恒男, 橋本泟治, 平野裕, 甘利正和, 佐藤雅英, 中野 徹, 三浦美樹, 伊藤要樹, 中村 聡 (由利組合総合病院)

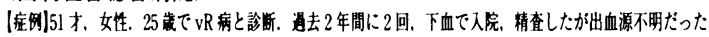

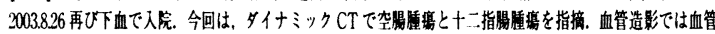

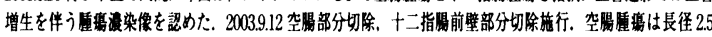

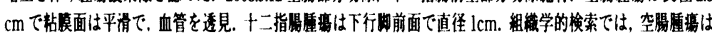

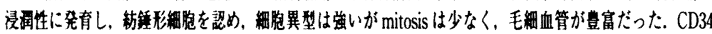

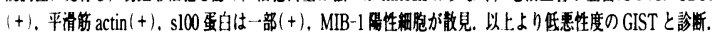

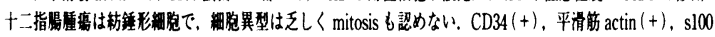

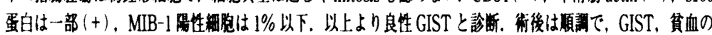

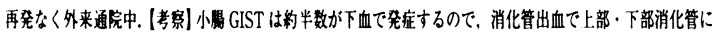

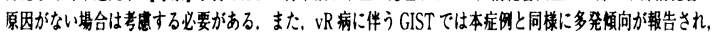

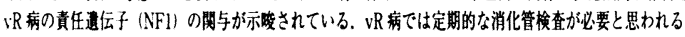

\section{PPS-3-289 小腸 GOST10 例の臨床病理学的検討}

豊島 明", 遠藤 健", 磯山徹", 酒井敬介", 丸山嘉…",

永岡 栄", 高島正樹", 板東隆文", 武村民子'”

(日本赤十字社医療センター外科"1, 日本赤十字社医療センター病理部 ${ }^{21}$ )

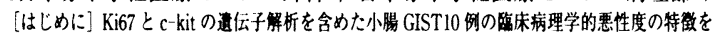
調べ，その予後と相関する因子を検討した. [方法] 週去 29 年間に我々が経倹した 10 例の小腸 GIST 対象とした. H-E 染色に加え，c-kit, CD34, SMA, S-100, Ki-67の免疫染色を行った. 隀鹪往, M. F. (mitotic figure), Ki-67の L. L (labelling index), c-kit exonll のシークエンス解析

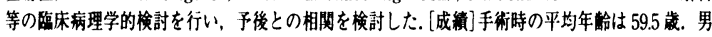

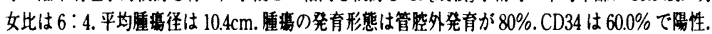
j生率は $50.0 \%$. 平均生存期間は 62.3 ケ月. M. F. 高度群は 3 解で, いずれも Ki-67の の.I.は高值 で予後は悪い頓向にあった。手術後6ヶ月以内に亡くなった 2 症例はいずれも M.F. は高度淂性, Ki-67の L. I. も高く、V-factor も强陽性であった。また

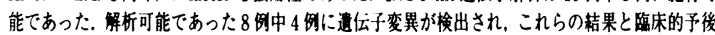
この関倸についても検討を加えた. [落語]小晹 GISTにおいては M.F. Ki-67の の. I., V-factor, c-kit 遭伝子解析等が䧗床的悪性度評価として重要である叮能性が示惨された。

PPS-3-290 消化管出血で緊急手術を行った小晹熄室原発 gastrointestinal stromal tumor $の 1$ 例 城野晃一", 西田智樹", 大迫 智", 白井智彦", 池田栄人 ${ }^{2}$, 栗岡英明 ${ }^{2}$

(国立舞鶴病院外科"，京都第…赤十字病院外科 ${ }^{23}$ )

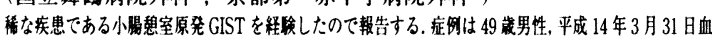

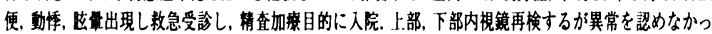
た. 出血シンチでRの集皘を認めず，下血が持続し会血を行ったが筫血が進行するため，4月3日血管

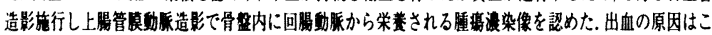

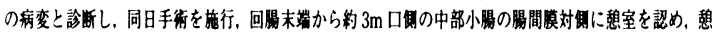

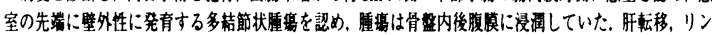

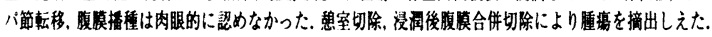

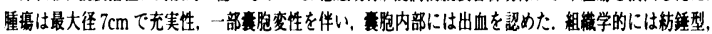

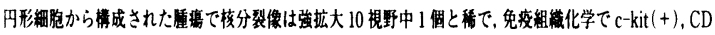
$34(+)$, vimentin $(+), \alpha$-SMA $(-)$, desmin $(-)$, S-100protein $(-)$, Ki-67 labeling index $\$ 5 \%$ てあった。 組僟診断は Gastrointestinal stromal tumor, uncommitted typeであった。

PPS-3-291每胞状形態を呈し診断に難渋した空腸 GIST の 1 例

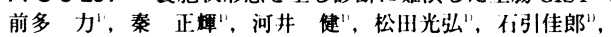
策野俊記"，小合加奈子" ${ }^{2}$

(順天堂大学消化器外科講座 (下部消化管外科) ${ }^{1}$, 順天堂大学第 1 病理 ${ }^{21}$ )

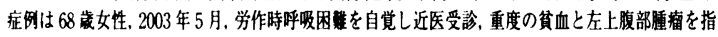

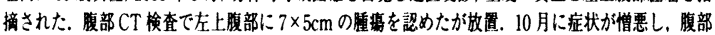

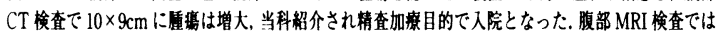

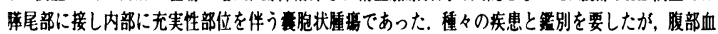

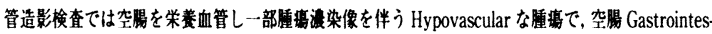

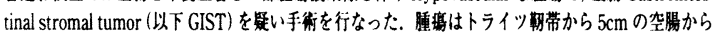

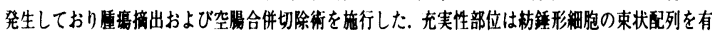

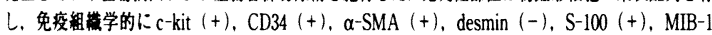
index $5 \%$ 末满，稩胞分裂像数は $5 / 50 \mathrm{HPF}$ 末满であり空渴 GIST, combined smooth muscle-neural

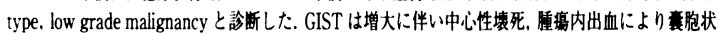

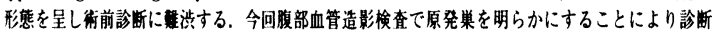

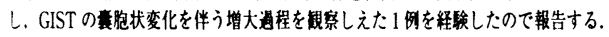

PPS-3-292 腫瘍内出血による激しい痛みのため緊急手術となった空 腸 GIST の 1 例

松本 譲, 箫嶋哲文, 平口悦郎, 村上貴久, 寺本研一

(函館中央病院外科)

ははじめに|GIST は時に腫場内出血をきたし，そのために軽度の痛みや腫瘤を触知することで 発見され待機手術となる例は散見されるが，激しい痛みのため緊急手術となった報告例は我々 の譯べた範用ではまだない.今回, 腫瘍内出血による腫瘍の急激な增大のため, 激しい痛みを生 し㗨急手術となった空晹 GIST の1 例を経験したので報告する. (症例】 68 歳, 男性【現病歴】H 15 年 11 月 22 日早朝, 突然, 左上腹部痛あり当院内科受診 [既往歴] 65 歳, 当科にて虫垂切除 術ICT)左腹部に内部不均一に造影される腫嘴を認めた. [H12 年 CT) 空腸起始部に小晹壁肥厚 像を認めた. 以上より空腸 GISTの腫場内出血と診断した. 上腹部痛が強く，腫瘍破裂の危険が あるため同日㗨急手術となった【手術】空腸起始部に $14 \mathrm{~cm}$ 大の管外性発育を示す血腫を伴う

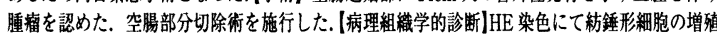
を認め, mitosis は 17/50 HPFであった. 免染では c-kit 陽性, malignant 空腸 GIST と診断した。 はまと】 GIST は短期間で急速に増大し破裂することもあるため, CT 上, GISTに腫場内出血 を伴い激しい痛みを認めた場合は早急な外科的治療が必要となると考えられた。

PPS-3-293 メシル酸イマチニブが著効し, 化学療法後に治痹切除し えた小腸 GIST 後腹膜再発の 1 例

湊 栄治, 大竹耕平, 藤野一平, 松本収生, 嶋廣一

(新宮市立医療センター外科)

症例は 48 歳の男性. 2002 年 3 月に腹部腫瘤を主訴に来院した. 小晹腫瘍の診断で小 腸部分切除術を施行した. 免疫組織化学的検索にて c-kit 及び CD34 陽性, S-100, $\alpha$ -SMA 共に陰性の小腸 gastrointestinal stromal tumor（GIST）であった. 2003 年 9 月頃より右側腹部痛を認め近医受診したところ，腹腔内腫嘴を認め当科紹介受診と なった. 腹部造影 CT 検査では, 右副腎近傍に充実性部分は骨格筋と同等に造影され 一部に軎胞性変化を伴った直径 $8 \mathrm{~cm}$ 大の腫瘍を認めた. 腹部血管造影検査にて腫瘍

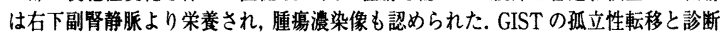
し, 切除を第一に考えたが, 腫湟の大きさ, 局在より術中の disseminationの可能性 が高いと考えられた. Neoadjuvant chemotherapy として, 近年有効性が報告されて いる、メシル酸イマチニプ連日投与 $(400 \mathrm{mg} / \mathrm{day})$ を開始した，大きな副作用も無 く 30 日間連日投与を行なったところ，著明な腫堭径の縮小を見た，2003年 11 月， 腫嘴摘出術を施行したところ, 病理組織学的に小腸 GIST の再発であった.

PPS-3-294 12 年後に肝転移再発をきたした小腸 Gstrointestinal stromal tumor (GIST) の一例

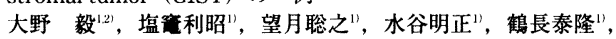

福井 洋", ${ }^{11}$ 田口 尚 ${ }^{2}$

(長崎記念病院外科 ${ }^{1}$, 長崎大学大学院第二病理 ${ }^{21}$ )

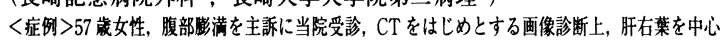
に約 $20 \mathrm{~cm}$ の多血性の充実性成分と内部に出血を来した海胞性成分を伴った腫演を認めた，腹腔

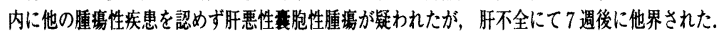
Necropsyにて spindle cell tumor, C-kit 強陽性であったことから転移性の Gastrointestinal stromal tumor が考えられた. 後に 12 年前の小晹腫瘍の既往が判明, 病理組織にてC-kit 強陽性を確 認, 小腸 GISTの 12 年後の肝転移再発と確診された。両者ともSMA 陽性, S100 陰性のSmooth muscle type で, 特にCD34 は陰性であったものが今回陽性に転じていた。くまとめ〉本症例のよ うに消化管 GIST はまれに治療後長期生存例があり，十分な資料が入手困難なため診断に苦虑す る場合がある. 今回得られた画像所見は他の肝衰胞性疾患との筑別も考虑に入れ貴重な所見と考 えられた．また，異時性転移例における原発巣と転移宩の形質の変化について報告は少なく今回 得られた組蟣のCD34の染色性の変化は GIST の形質転换に関連する重要な知見と思われた.

PPS-3-295 腹膜播種にて再発した GIST の 2 例 山口祐二, 遠藤俊吾, 辰川貴志子, 石田文生, 加藤博久, 日高英二, 出口義雄, 永田浩一, 田中淳一, 工藤進英 (昭和大学横浜市北部病院消化器センター)

はじめに Gastrointestinal stromal tumor (GIST)はカハール介在細胞由来といわれ， 悪性度の高いものでは, 再発もみられる.今回われわれは腹膜播種にて再発した小晹 GISTの 2 例を経験したので報告する. 症例 $1: 55$ 歳, 女性. 右下腹部痛にて来院. 腹部 CT にて骨整内に $10 \mathrm{~cm}$ 大の腫嘴性病変と少量の腹水を認めた。腸腫場穿孔 と診断し，腫場を含む小腸部分切除を施行した，腫場は免疫染色では CD 34, c-kit 陽性, 核分裂像も高度で malignant GIST と診断した. 術後, 1 年 8 ケ月目に腹膜播 種にて再発した. 症例 $2: 70$ 歳, 女性. 下腹部の違和感にて来院. 腹部 CTにて骨监 内に $10 \mathrm{~cm}$ 大の腫堭性病変を認め, 卵巣腫場の診断にて手術を開始した。分割にて腫 場の大部分を切除したところで小腸腫場と診断され，起始部を含め, 小腸部分切除を 施行した。腫寉は免疫染色で CD34, c-kit 陽性であり，核分裂像が高度であったこと から malignant GIST と診断した. 術後 8 ヶ月目に骨整内に腹膜播種にて再発した. まとめ GIST の治療においては en bloc resection が重要であると考えられた。 
PPS-3-296 大動脈溜破裂手術時偶然切除され，後に播種性転移をき たした小腸 GIST の 1 例

秋吉高志", 徳永正則", 森田 真", 山本一治", 脇山茂樹", 池部正彦"，橋本光孝"，豊增泰介"，長家 尚"，大屋正文" (飯塚病院外科" , 飯塚病院病理 ${ }^{21}$ )

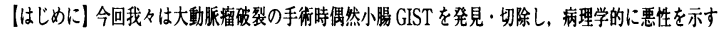

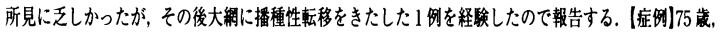

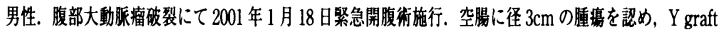

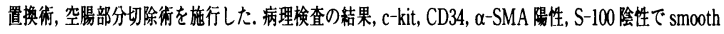
muscle type の GIST と診断された。核分裂像はまれであり, MIB-1 labeling index も低く, 病理組满上

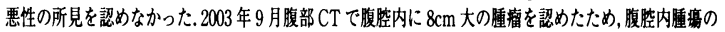

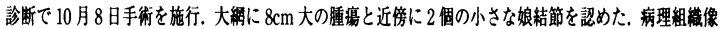
は前回切除した小腸 GIST と類似していたが, 分裂像は多〈記められた。 ともにc-kit 遺云子の exonll

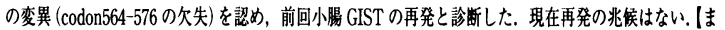

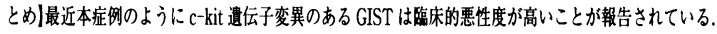

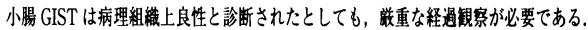

PPS-3-297腫瘍破裂による腹腔内出血から出血性ショックをきたし た小腸 GIST の 1 例

沖田理貴, 青儀健二郎, 棚田 稔, 平 成人, 沖田充司, 柿下大一,

石崎雅浩, 久保義郎, 栗田 啓, 高嶋成光

(国立病院四国がんセンター外科)

腫瘖破裂から出血性ショックを呈した小腸 gastrointestinal stromal tumor (GIST) 症例を経験した. 症例は 59 才, 男性. 肝機能障害の精査中に腹部 CT 検査で腹眭 内腫瘤を指摘された. 小腸透視直後にショックとなり，㗨急開腹を行った. 腹脄内 には $1000 \mathrm{ml}$ を超える多量の出血を認め, 回腸に長径 $18 \mathrm{~cm}$ 大の壁外発育型腫嘴を

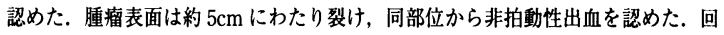
腸切除を伴う腫瘤摘出術を施行し, 第 10 病日に軽快退院した. 免疫組織化学的染 色より GIST, uncommitted type と診断した. 小腸 GISTによる出血は消化管出血 が多く, 腹些内出血の報告は本邦において 13 例のみと, 極めて稀である. 13 例中 10 例が男性, 全例壁外発育型, 腫場径は 4-18cm と比較的大型, などの特徽がある. 診断においては従来より小腸透梘が行われてきたが, 本症例は腫痽の圧迫を契機 に破裂したと思われた，検査時の侵裝は最小限にとどめるべきことを痛感した。

PPS-3-298 術前に回腸悪性リンパ腫と診断し, 術後悪性リンパ腫の 自然退縮を認めた 1 例

浅井陽介"，中村利夫"，林 忠毅"，東 幸宏"，宇野彰晋"，

深澤貴子1"，丸山敬二1"，今野弘之"，中村 達"，相村春彦"

(浜松医科大学第 2 外科 ${ }^{\prime \prime}$, 浜松医科大学第 1 病理 $\left.{ }^{21}\right)$

今回われわれは, 大腸内視鏡検査により，術前に回腸覀性リンパ腫と䛦断し，術後 病理にて悪性リンパ腫の自然退縮を認めた 1 例を経験したので報告する.患者は 39 歳, 男性. 3 年前より腹部不快感を自覚したが, 放置していた。平成 15 年 4 月下旬に, 腹痛, 血便を認めたため, 近医受診. 同年 5 月上旬, 近医より当院当科 紹介受診した。 大腸内視鏡にて, 回盲弁から脱出寸る径 $3 \mathrm{~cm}$ の隆起性病変を認め, 回腸腫嘴による大腸内への腸重積と診断した．同病変の生検から悪性リンパ腫 (marked lymphoid infiltration, malignant lymphoma, jejunum) と診断. 全身検 索にて回盲部に限局している消化管原発覀性リンパ腫と診断し，同年 6 月 13 日 に, 回盲部切除術を施行した。標本での病変の大きさは径 $2 \mathrm{~cm}$ と縮小しており, 術後病理にて悪性リンパ腫像を認めなかった (marked lymphoid infiltration, not otherwise specified，jejunum). 術後経過は良好にて， 6 月 27 日退院となった。

PPS-3-299 術前に診断可能であった回腸末端部悪性リンパ腫の 2 例 前村 誠", 小倉芳人", 山本克己", 愛甲 孝"

(国立療養所南九州病院", 鹿览島大学第 1 外科 ${ }^{21}$ )

腹痛，便秘で大腸ファイバー（以下 CF）施行し，発見された回腸末端部悪性リンパ 腫の 2 例を経験した，症例 $1: 69$ 歳，女性，主訴：右下腹部痛，現病歴：H15 年 6 月頃より下腹部痛あり。腹痛持続するため, 11 月 6 日 $\mathrm{CF}$ 施行し, 回盲部に 1 型の腫 場を認め, 手術目的にて入院. 回盲部悪性リンパ腫の診断にて右半結腸切除施行, 術 中回腸末端の腫湟がバウヒン弁に向かって先進部となって晹重皘を呈し，摘出標本で は回腸末端部に 2 型の病変あり。症例 $2: 64$ 歳, 女性, 主訴：便秘, 現病歴：便秘が 持続するため当院受診し,CF 施行. 回盲部より約 $10 \mathrm{~cm}$ 口側までの回腸末端の粘膜の 強発赤と浅いびらんあり, 生検にて慢性炎症のみ, CF 再検し生検にて悪性りンハ腫 を疑い入院, 11 月 27 日回盲部切除施行, 摘出標本では回腸末端部に約 $6.5 \times 6 \mathrm{~cm}$ のほ は全周性の病変あり。まとめ：腸悪性リン八腫は術前から確定診断がつくことは稀 で, 腸重皘，腸管穿孔を起こして緊急手術時に発見されることが多い，本症例は 2 例とも便秘, 腹痛といった自覚症状のみであったが $\mathrm{CF}$ 施行時に回腸末端部まで観察 することで, 術前に存在診断が可能であり，病変の外科的切除が可能であった。
PPS-3-300 小腸原発 $\mathrm{T}$ 絊胞性蝟性リンパ腫の 3 例 信岡大輔, 松野 風, 渡辺哲也, 買原彰彦, 日置勝義 (済生会今治病院外科)

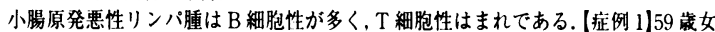
性, 主訴は下腹部䓶. 沉発性腹膜炎にて䋈急手術を施行したところ, 回腸末端部よ

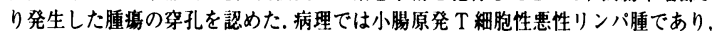
術後にCHOP 療法を 2 クール施行した.術後 4 年間無再発であったが他病死した. 【症例 2】 50 藏男性, 主訴は下腹部㾢. 小腸原発悪性リンバ腫の疑いにて待機手術 を施行すると，回盲弁から $80 \mathrm{~cm}$ の回腸に腫珻を認めた，病理では小晹原発 T 細胞 性悪性リンバ腫であり，術後 CHOP 療法を 8 クール施行したが，術後8ヶ月で再

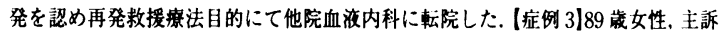

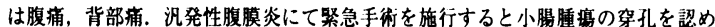
た. 病理では小晹原発 T 細胞性悪性リンバ腫であった。術直後より全身状態不良で

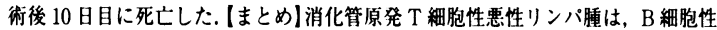
に比べて化学療法が奏効しにくく，予後不良とされている. 当院の 3 例も子後不良 であった．今後，抗体療法など有効な治療法の開発が望まれる。

PPS-3-301＼cjkstart腸管穿孔をきたした小腸悪性リンパ腫の 2 例 関野誠史郎"，水谷知央"，森美樹"，松友賽和"，小久保光治"， 佐治重豊"，笹阙郁乎"

(木沢記念病院外科"，木沢記念病院病理検查等 ${ }^{2}$ )

晹管穿孔をきたした小晹悪性りンバ腫の 2 例を経输したので報告する。症例 1 は 56 才男 性. 上腹部痛を主訴に来院した，上部消化管内梘鏡検榃，注晹検査では異常を認めず，小

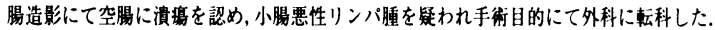
転科 3 日後に腹部全体に強い自発㭪，筋性防御認め，腹部 Xpにて free air 認め，消化

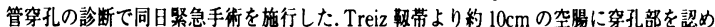
その周囲には謴場が多発しており，晹間膜リンバ節の腫大を認めた。 空腸部分切除術を施 行し, 術後 24 病日で多滕器不全に陥り死亡した。病理組織結果は Malignant lymphoma diffuse lymphoma, large cell type と診断された。症例 2 は 69 才男性. 突然の腹扁と哋 を主訴に来院．腹部は全体に筋性防御を認め，同日聚急手術とした，ハウヒン弁より 5 $\mathrm{cm}$ 口佣の回腸に $8 \times 8 \mathrm{~cm}$ の腫鹪を伴った $3 \mathrm{~mm}$ 大の穿孔を認め，回盲部切除を施行し た。病理組織結果は Malignant lymphoma, diffuse large B cell type であった。術後経通 良好で術後 3 力月となるが，現在再発なく他院にて化学撩法施行中である。

PPS-3-302 2 度の穿孔を起こした小腸原発 $\mathrm{NK} / \mathrm{T}$ 細胞悪性リンパ腫 の一例

古川秋生, 諸角強英, 宮崎洋史, 五月忠一, 仲丸誠, 河息俊文, 平岩訓彦、鎌野俊彰

(公立福生病院外科)

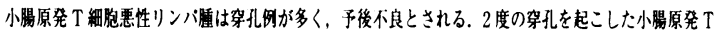

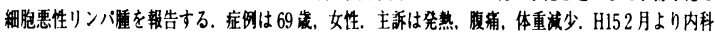

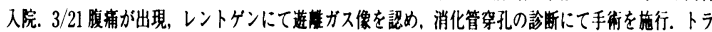

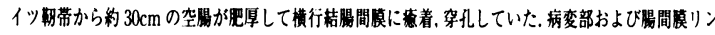

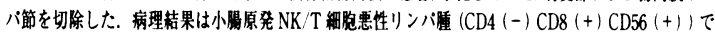

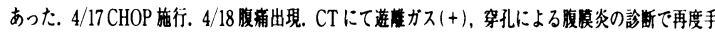

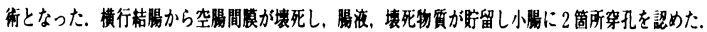

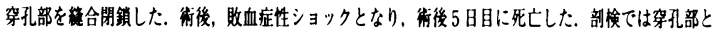

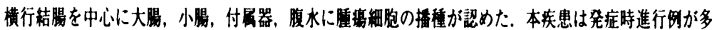

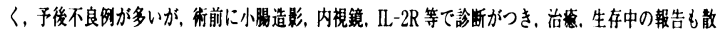

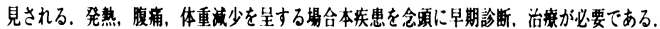

PPS-3-303 完全内滕逆位症に合併した穿孔性腹膜炎をきたした小腸 悪性リンパ腫の 1 例

菅野雅彦，高橋玄，塚田健次，細时諴弥，笛木裕一，圾本一博， 鉡野俊䄫

(順天堂大学消化器外科学講座（下部消化管外科）)

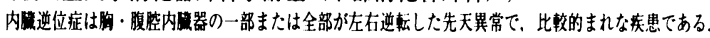

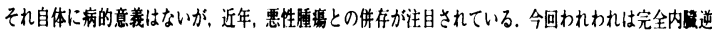

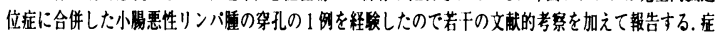

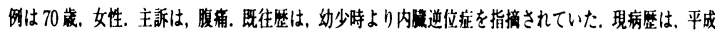

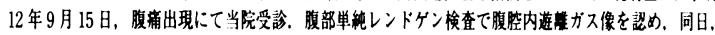

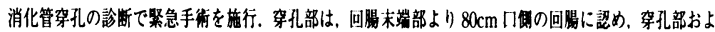

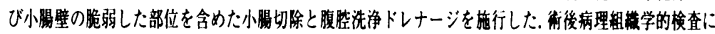

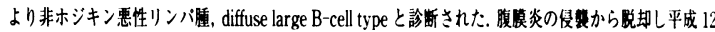

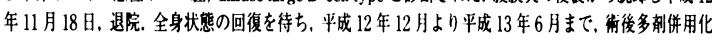

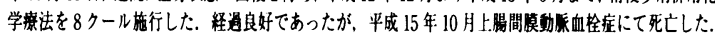

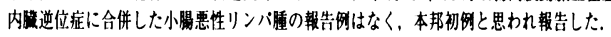


PPB-3-001副腎機能からみた消化器手術術式別侵唄度の評価

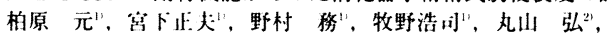

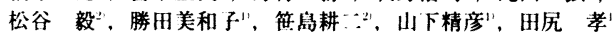
(日本医科大学大学院滕器病態制御外科"，日本矤科大学多糜永山病院外 科”)

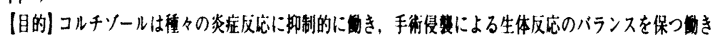

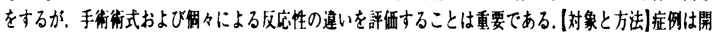

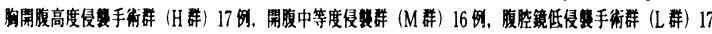

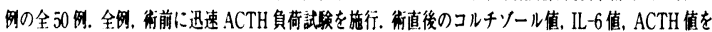

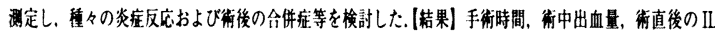

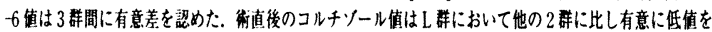

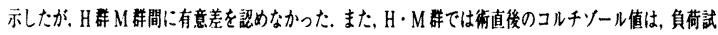

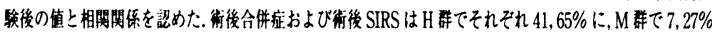

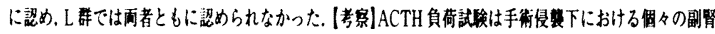

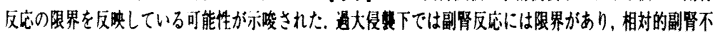

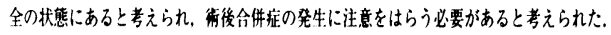

PPB-3-002 消化器外科領域における全身性炎症反店症候群に伴う急 性肺障害の検討

横山義信, 長田拓哉, 野澤聡志, 笹原孝太郎, 阿部秀樹, 坂東 正, 廣川慎一郎, 塚出一博

(富山医科楽科大学第 : 外科)

(目的) 全身性炎症性反底症垁辟 (SIRS) に伴方急性脚障害 (ALI) の発症に好中球工ラスターゼ か重要な役㓶を果たしていることが報告されている。今问，この好中球エラスターゼの阴害莱であ

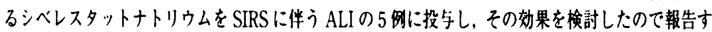

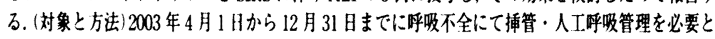

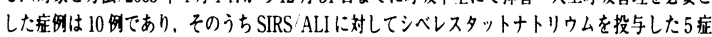

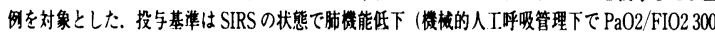

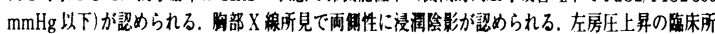

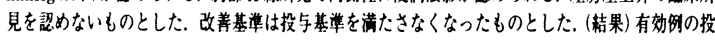

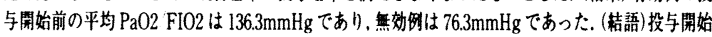

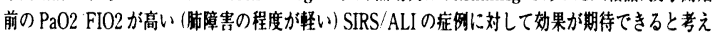
られ、シベレスタットナトリウムを積栖的に投与し，救命事の向上に努めていきたい。

PPB-3-003 大腸精術後の血中 IL- 6 と TNF- $\alpha$ および炎症反応の検 討一腹腔鏡補助下手術と開腹術の比較一

角崎秀文, 榎本雅之, 小鴄一幸, 山博之, 川下俊樹, 植竹宏之,

安野正道, 牧野博司, 朴成進, 杉原揵一

(東京医科歯科大学大学院消化機能再建学)

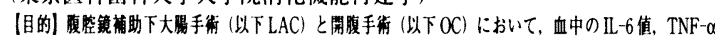

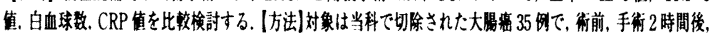

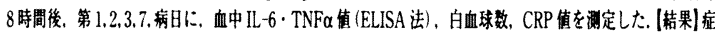

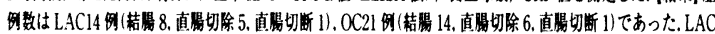

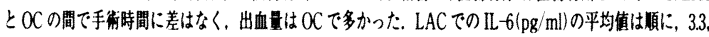

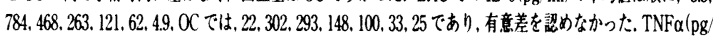

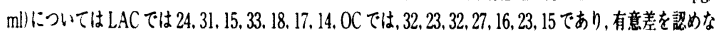

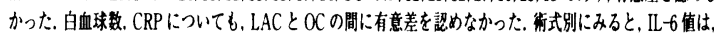

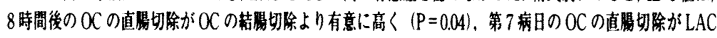

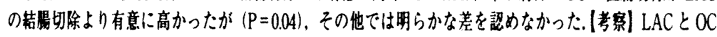

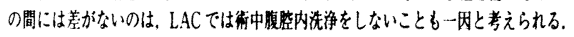

PPB-3-004 胃精および大腸癌手術と肥満：Body mass index からみ た手術難易度と手術侵㜔について

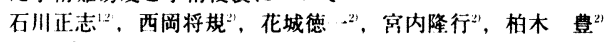

(徳島赤十字病院外科", 闻立高知病院外科"')

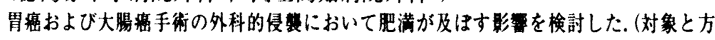
法) 開腹手術を行った胃癌症例 51 洌（幽門湖胃切除術 32 例，胃全摘術 19 例）と大腸缩

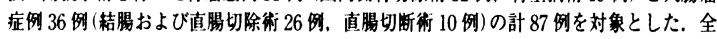

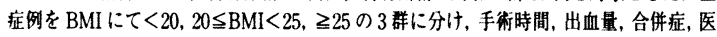

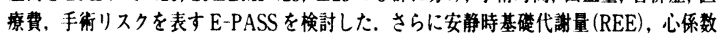

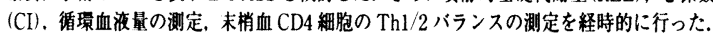
なお各手術は経䌼が 15 年以上の術者 3 名によるチームで行われた。(成諘)術後合併症は 幽門倒胃切除術で 4 例，胃全摘術で 3 例，結腸および直腸切除術で5例，直晹切断術で 4例であったが, BMIにより有意差はみられなかった。 また手術時間，出血量，医療費， REE. CI, Th1 2 バランス, E-PASS score も冬群間に有意差はみられなかった（䊅語)

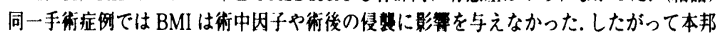
では手術適応や術式の選択に BMI はさほど考慮する必要がないと思われた。
PPB-3-005 高脂血症と消化器がんのリンパ節転移との相関 北山丈二, 酒向晃弘, 波多野賢二, 甲斐崎祥一, 石神浩德, 中山 洋, 石川 誠, 朝险正宏, 山下裕玄, 名川弘一

(東京大学大学院腫瘍外科学)

(目的)变転移における脂質の関与についての検討は少ない。高脂血症の存在とリンパ節転移の 相関を消化器瘦にて解析, リンバ転移と脂質代諆との関俰を考察した. 1987-2002年で, 術前空 腹時の血整 Total Cholesterol 值 (TC) と Triglyceride 值 (TG) が測定されていた胃癌 673 例, 表在食道瘦 54 侧, 早期大腸癌 80 例で, リン八節転移との関連を儖床病理学的因子と共に解析し

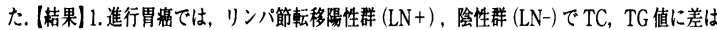
な⿰力た。一方, 早期胃瘦 353 例中, 33 例に転移を認め, LN+群は LN-群に比べ, 有意に高い 血清脂質值を示し (TC；200.4 $\pm 34.7 \mathrm{mg} / \mathrm{dl}, 184.2 \pm 34.1 \mathrm{mg} / \mathrm{dl}, \mathrm{TG} ; 127.7 \pm 62.1 \mathrm{mg} / \mathrm{dl}, 108.9 \pm$ $50.6 \mathrm{mg} / \mathrm{dll}$, 高脂血症の割合も有意に高革であった.2.この傾向は, 男性 225 例ではより影著で， 高脂血症は独立した早期胃程のリン八節軽移予測因子であったが，女性 98 例では相関は認めな

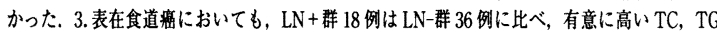

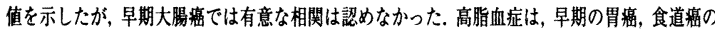
リンバ転移の䢔程で，有利な環境をもたらしている可能性が示惨された。

PPB-3-006 食道癌の再発に及ほす術後合併症の影響についての検討 宮下正夫"，野村 務"，牧野浩司"，丸山 弘"，二見良平"， 柏原 元"1, 勝田美和子"，高橋 健"，笹島耕二 ${ }^{21}$ ，田尻 孝 (日本医科大学大学院臟器病態制御外科 ${ }^{1}$, 日本医科大学多摩永山病院外 科到)

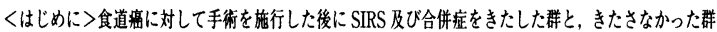

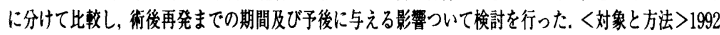
年加 2003 年に，食道密に対して手術を施行した後再発をきたして死亡した 44 症例を対象として，術 後のSIRS 及び合併症の有無と, 術後再発までの期間及ひ予後との関連性について繳計学的梌討を行つ

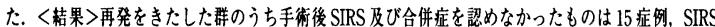
及び合併症を㥖めたものは 29 症例であった，両群間で術後再発までの期間を検討すると，SIRS 及び合

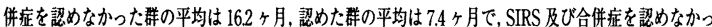
た群のはうが再発までの期間が長い煩向にあった，同粎に，予後についてもSIRS及び合併症を認めな かった洋のほうが予後が延長する煩向にあった。考察〉手術後，SIRS 及びその他の合併症をきたし，

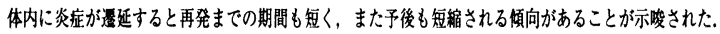

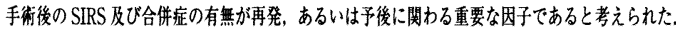

PPB-3-007 炎症性サイトカイン産生から見た外科的侵襲後の肝転移 制御法の確立

倉田昌直"，川本 徹"，岡鴄研二2"，大河内信弘 ${ }^{1}$

(筑波大学消化器外科 ${ }^{11}$, 熊本大学大学院病態情報解析学分野 ${ }^{2}$ )

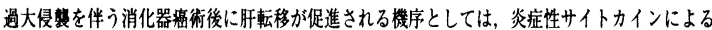
接着分子の発現や数洞内微小循理障害が引き金となる。我々はサイトカイン産生を抑制する Prostacyclin (PGI $)$ ならびに類河内皮緗胞加の PGI, 㦃生を促す Antithrombin (AT) に着目

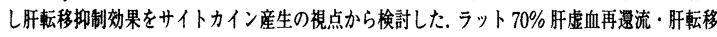
モデルを用いてi）AT投与群ii) PGI投与群 iii) 生食投与群, Indomethacin (IM) で前処置を した後にATを投与したiv) AT+IM 群における術後7日目の肝転移数ならびに虚血再灌流後 の血清 AST 值, 肝組縟中の TNF- $\alpha$, IL-1B, 6-keto-PGF 值を測定した. AT, PGI群では生

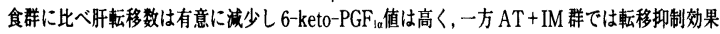
は認められず, 6-keto-PGF。值は上昇しなかった，IL-1BはAT, PGI群では生食群，AT+IM 群と比較し有意に低值を示した.ATおよびPGI忙炎症性サイトカインの上昇を抑えることで 肝虚血再䢙流後障害を揤制し肝転移形成を制御すると推測された，また ATはPGI2産生を促進 することで炎症性サイトカインの生成を狮制し，転移抑制効果を発揮すると考えられた。

PPB-3-008 肝血行遮断が再灌流障害, 大腸癌肝転移形成に与える影 帮一遮断時間による比較検討

吉田 誠, 中村誠昌, 土居幸司，打波 大，田中國義 (福井大学第 2 外科)

[背景と目的】肝血行遮断は外科侵襲で, 産生される炎症性 mediater が再灌流障 害の原因で, 癌紐胞增殖にも関与する. 肝血行遮断後の再灌流障害, 大腸癌肝転 移を連続遮断と間歇遮断で比較. [方法】 rat 虚血再灌流モデルで対照群：120 分の 開腹, 連続群 : 60 分遮断- 60 分再灌流, 間歇群 : 15 分遮断一 15 分再灌流を 4 回反 復と設定. 肝組織血流量, 逸脱酻素值, 肝エネルギー代謝, 血中 cytokine 值, 肝 組䄳 free radical 量を測定.腫場細胞を脾注し肝転移と E-selectin mRNA を定量. 【成績】肝組織血流量, 肝エネルギー代謝は連続群より間歇群が保持された。迼脱 醅素值, 血中 cytokine 值, 肝組穖 free radical 量も間歇群が低値. 肝転移は連続群 は対照群より增加したが，間歇群は連続群より減少した，E-selectin mRNAも連 続群より間歇群は低值. [結諭】 間歇群は連続群より炎症性 mediater 産生が低值 で, 肝 viability も保持されたことから間歇遮断は低侵䪭であり, 間歇群の E-selectin 低発現が旰類洞内皮への接着を制限し転移減少に寄与したと考える。 
PPB-3-009 肝切除術後肝不全症例の検討

中村 登, 浜田信男, 菰方輝夫, 門野 潤, 槐島健太郎, 島元裕一, 川島英夫，坂田隆造

(鹿児島大学大学院 循環器 ·呼吸器 ·消化器疾患制御学)

【目的】肝切除後肝不全症例を検討し，危険因子，治療方法，その成績について検討 した. [対象と方法] 過去 5 年間に施行された肝葉切除以上の 33 例を対象とした. 12 例 $(36 \%)$ に対して門脈塞栓術を先行させた. 術後に総ビリルビン高值の持続 $(3 \mathrm{mg} /$ dl 以上, 1 週間以上）を呈し，各種補充療法のみで肝機能の回復が得られなかった症 例を肝不全症例とし, 治療方法および結果を梌討した. 全肝不全症例に高気圧酸素療 法 (2気圧, 90 分間/日) を併用した!結果】術後肝不全は6 例 (18\%) であり, 高気 圧酸素療法開始時の総ビリルビン值は $7.0 \pm 2.6 \mathrm{mg} / \mathrm{dl}$ であった．2例 $(6 \%)$ は術後急 速に高ビリルビン血症が進行し，血液浄化療法を併用したが敗血症に陥り多滕器不全 で死亡した，4例は高気圧酸素療法と種々の肝庇蓄・補充療法で回復した. [結語】肝 不全症例の予後规定因子は感染症であり，特に胆道系腫場では術前より潜在する胆道 感染が術後の宿主に多大な影響を与えることが示唆された. 高気圧酸素療法の肝不全 に対する効果のメカニズムはまだ不明ではあるが，その有用性が示唆された。

PPB-3-010 消化器外科（胃・大腸・胆赛）手術後における真菌の translocation の検討

前田壽哉, 淺沼雄之, 馬場有希, 高橋直人, 山口邦彦, 重田 博, 田中一郎

(聖マリアンナ医科大学東横病院外科)

ははじめに消化器外科術後における真菌 translocationの可能性について检討をおこなった

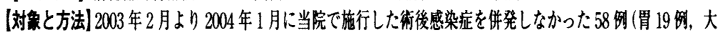

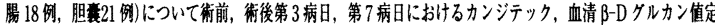

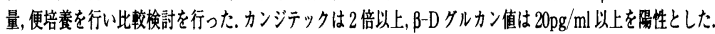

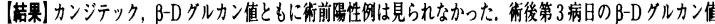

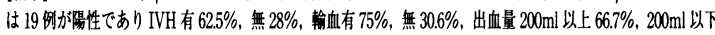

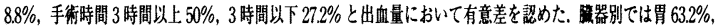

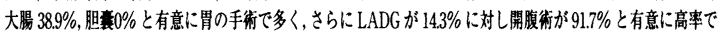

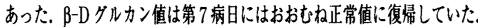

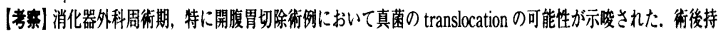
続する発熱ては早期に，深在性真菌庭を考虑した empiric therapy が必要である思われる。

PPB-3-011 合成吸収性結紮繾合系は消化管手術後の腹䏶内環境を改 善するかー腹水中 IL-6による評価一

森本泰介, 福光 剣, 松尾宏一，岩崎 稳，山本栄司，岩田辰吾， 中村吉昭, 向原純雄

(京都市立病院外科)

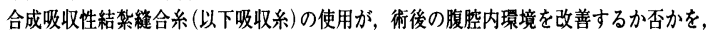
腹水中の IL-6 值測定を中心に評価検討した，胃症に対する幽門僛胃切除術症例におい て, 血管結禁，消化管吻合に絹系を使用した症例 5 例 (縝糸群)，すべて吸収系 (Vicryl) を用いた 5 例 (吸収系群) において，術後 $1,3,5$ 日目の白血球数，CRP 值， $38^{\circ} \mathrm{C}$ 以上の 有熟期間, 腹水中の $I-6$ 値を比較検討した. 白血球数, CRP 值, 有熱期間には有意の差 は認めなかったが，腹水中平均 IL-6 值は術前值 $1.0(\mathrm{pg} / \mathrm{ml})$ 以下で，組糸群で術後 1,3 , 5 日が40800,19860,8700であった。これに対して吸収系群では20090,11350, 8020であ ク，1 日目に吸収糸群が有意に低值であった $(\mathrm{P}<0.05)$. 今回の検討により腹水中の II -6値は開腹手術により急激に上畕し，その後状態が安定するにつれて娍少し，さらに吸 収系使用により IL-6值によって表される腹腔内炎症所見が軽減されていることが判明 した. 価格の問题解決が急がれるが, 吸収系の使用は推奖されるべきと考えられる。

PPB-3-012 Nafamostat mesilate は外科的侵襲による癌転移增強を 抑制する

土屋康紀", 大西康晴", 澤田成朗", 吉岡伊作", 長田拓哉",

阿部秀樹"，山岸文範"，済木育夫" ，塚田一博"

(富山医科薬科大学第 2 外科 ${ }^{11}$, 富山医科楽科大学和漢薬研病態生化学部 門")

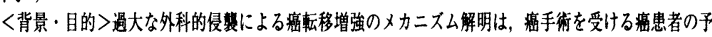

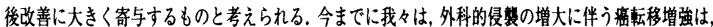
軽移紧発生母地における MMP-9, MT1-MMP，uPAなどのフロテアーゼの発現の增强が一因である と報告した(Tsuchiya et al. Surgery, 2003.)）この結果をふまえ，セリンブロテアーゼインヒビター である Nafamostat mesilate (FUT-175) が外科的唚算の增大に伴う㿋転移增强の抑制に有効と考え，

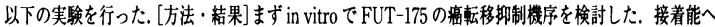

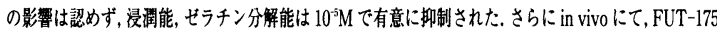

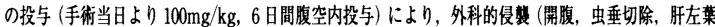

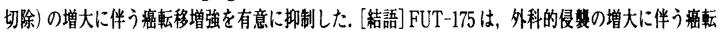
移增强の抑制に有効であるのと同時に，今までの報告と矛盾しないことが示唆された。
PPB-3-013 手術侵謷に上る術後免疫応答低下に対する補中益気湯の 効果について

木村元英，金井陸行，笹田折朗，木下浩一，高林有道 (田附興風会北野病院外科)

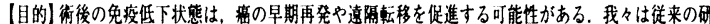

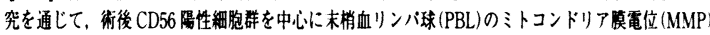

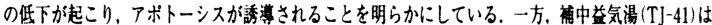

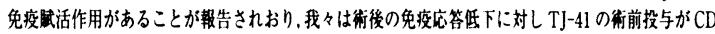

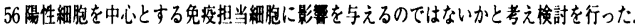

(方法】 投与群は，TJ-41；7.5g/日を術前 1 週間，投与。術前（投与前）及び街後 1 病日に採血し。

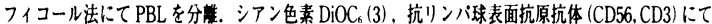

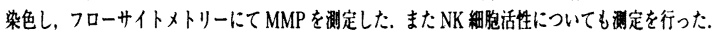

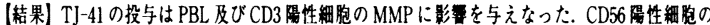

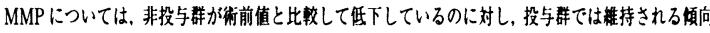
が認められた．NK 活珄についても同槏の䫅向が証められた。

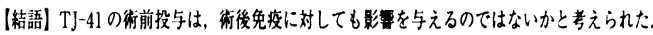

PPB-3-014 侵楽の時計遭伝子発現に及はす影霜について-LPS 投与 ラットモデルでの検討

岡田一幸, 矢野雅彦, 安夾間隆，岩永弊志，宮田博志，瀧[修司， 藤原義之, 安田卓司, 門田守人

(大阪大学大学院病態制御外科)

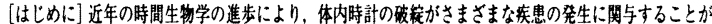

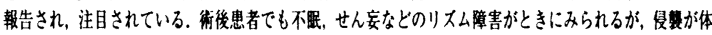

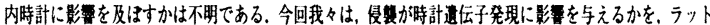

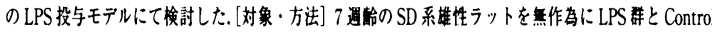

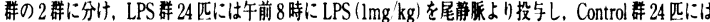

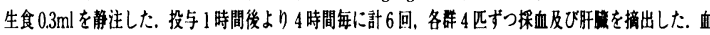

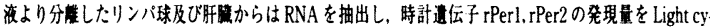

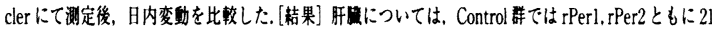

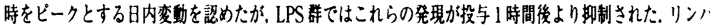

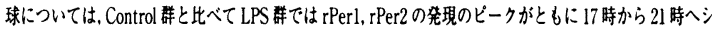

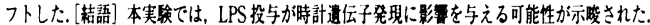

PPB-3-015 単純漫清冷保存肝・小腸グラフトの移植前短時間灌流は 再灌流後の微小循謤障害を軽隇する

正田茂樹 ${ }^{2.2}$ ，白水和雄"，谷川廣-“”，竹内正昭"，白水泰昌"，

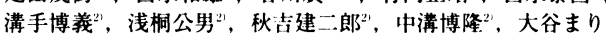

(久留米大学外科", 久留米大学小児外科 ${ }^{2}$ )

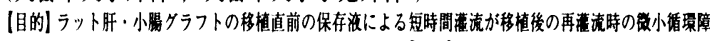

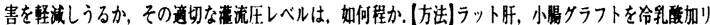

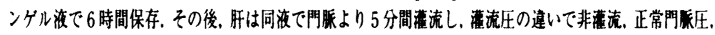

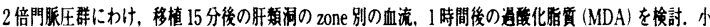

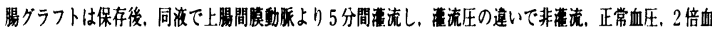

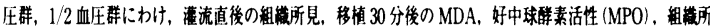

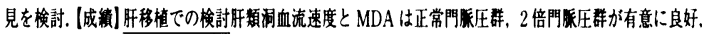

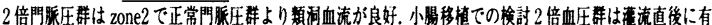

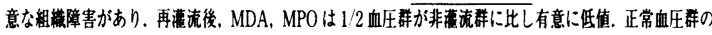

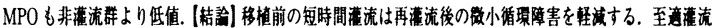

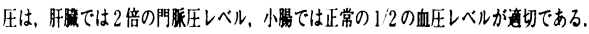

PPB-3-01690 藏以上の消化器外科手術症例の検討 加藤㶳治，岩崎純治，近藤昭倍，中川倰一，小倉嘉文 (松阪市民病院外科)

【目的と対象】過去 3 年間に当科で経験した消化器外科手術例 1041 例中 90 歲以上の手術

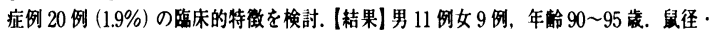

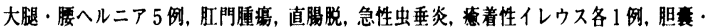

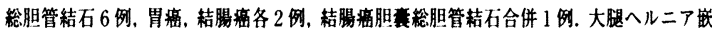

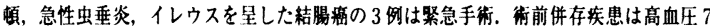

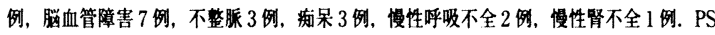

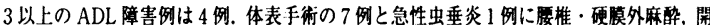
腹手術の 12 例に全身麻醉を選択. 全例で若年者と同粎の手術を施行. 胃盘では D1+ $\alpha$.

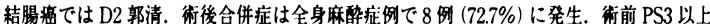

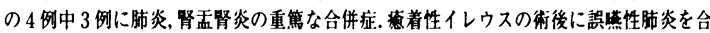

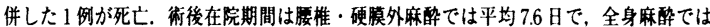
25.4 日. (結論] 90 歳以上の高秢者では慎重かつ迅速な術前管理，麻酶管理が重要である とともに，せん妄や嘼哭性肺炎などの特有の術後合併症に対する対策が必要である。 
PPB-3-01790 歳以上超高龄者開腹手術症例の検討-80 歳代高齢者症 例との比較一

山田 誠"，安藤公隆"，甲賀 新

(甲賀病院外科"，甲贺病院病理 ${ }^{2}$ )

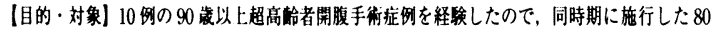

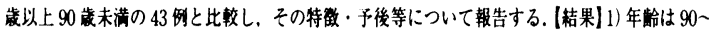

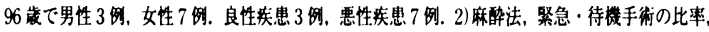

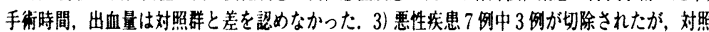
群の切除事 89.7\% に比べると有意に低加た. 4) 術前の Performance Status は 0 と 1 の症例か

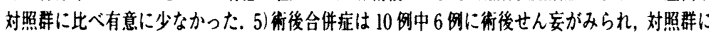

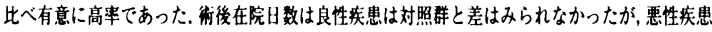

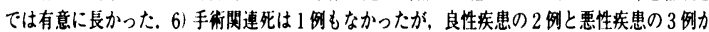

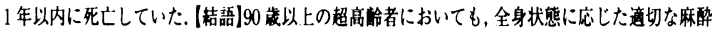
法・手衡術式を選択することにより，比較的安全に開腹手術を施行可能と考えられた。しかし，

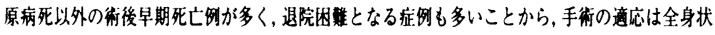
態のみならず，本人の社会的状況も踏まえて慎重に決定することが重要と考えられた。

PPB-3-018 高柃消化器外科手術患者に対する術後りハビリテーショ ンの導入について

星野宏光, 木村 豊, 加納寿之, 浅阙忠史, 岩澤 卓, 大西直, 東野 健, 中野芳明, 矢野浩司了, 門田卓士

(NTT 西日本大阪病院外科)

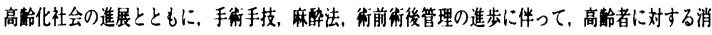

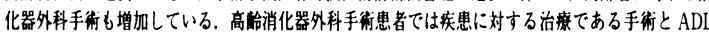

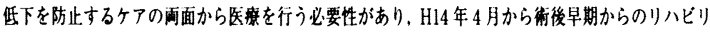

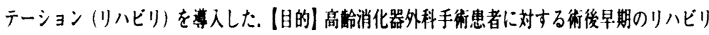

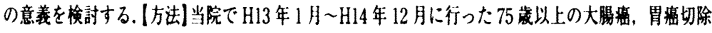

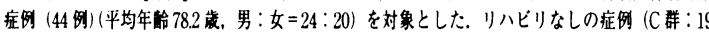

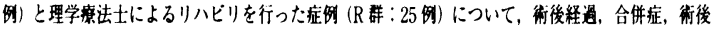

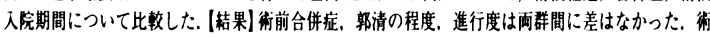

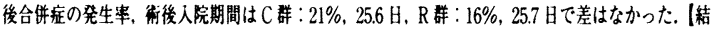

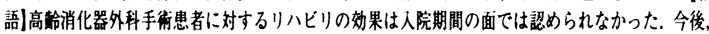

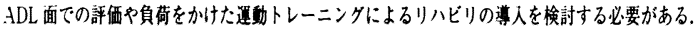

PPB-3-019 高軨者における外科手術術後早期合併症発生予測につい ての検討

江口和哉'，池 秀之"，深田伸…" 川 川村 孝”，安藤昌彦

嶋田 紘

(藤沢市民病院外科", 横浜市立大学消化器病センター2), 横浜市立大学第 2 外科 ${ }^{3}$, 国立㙩養所中部病院

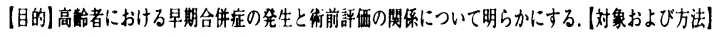

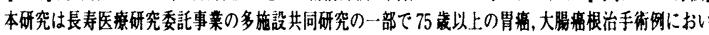

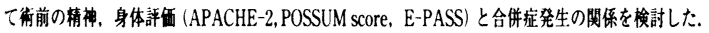

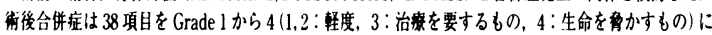

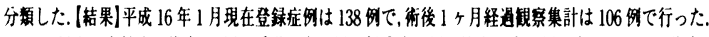

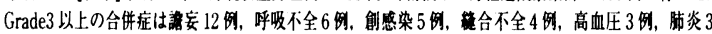

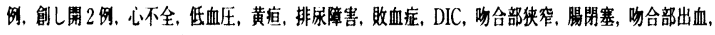

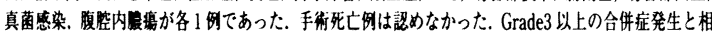
関がみられたのは POSSUM scoreの OSS および morbidity rate と E-PASSにおける PRS 及びCRS

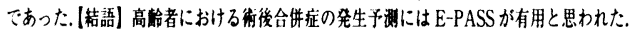

PPB-3-020 消化器外科術後せん妄急性期における Tiapride の有効 性について

平松和洋, 長鴄孝昌, 水上泰延, 重田英隆, 新美清章

(遠州総合病院)

【目的】Tiapride を術後せん妄急性期に投与し，その有効性を检証する。対象お よび方法了術後せん妄例の急性期治撩に 2003.3 12 の7 例には Tiaprideを用い (A 群), 2002.1 2003.2の 9 例には従来どおり haloperidol のみを用いた(B 群). この両群に NEECHAM confusion scale (NCS) を用いて術前 (Dp)，せん妄発 生前日 (D-1)，発生日から7日目まで (D0〜D7) レトロスペクティブに診療記

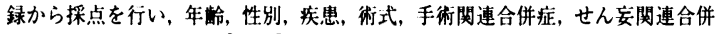
症と共に比較検討した. [結果】年龄, 性別, 疾患, 術式, せん安発生日, 手術関 連合併症では両群に差異はなかった。 せん妄回復日は A 群がより早期であった (A 群 $3.2 \pm 1.3$ 日, B 群 $4.7 \pm 0.8, \mathrm{p}=0.006$ ). NCS は D3, D4, D6 で A 群が高値を 示した $(\mathrm{p}<0.05)$ ．せん妄関連合併症はB 群で高類度に発生した $(\mathrm{A}$ 群 1 例, B 群 9 例, $\mathrm{p}=0.0009$ ). [結論】 Tiapride 投与は従来の haloperidol 単独投与よりも せん妄治療に対し即効性があり，せん妄関連合併症を有意に減少させた。
PPB-3-021 過疎地域における重複癌・異時性多発癌の増加について 工藤通明 ${ }^{122}$, 金井伸行 ${ }^{122}$, 平澤敏昭 ${ }^{11}$, 中林利博2), 桑野博行 ${ }^{21}$

(鬼石町病院外科", 群馬大学大学院病態総合外科学 ${ }^{21}$ )

【目的と背景】高齢者の割合が高い地域で，悪性腫瘍症例の経過観察により，重複癌お よび異時性多発癌の検討を行なった. 【対象と方法】 1998 年 4 月より 2003 年 12 月に, 当院を受診し，悪性腫場の磪定診断を受けた症例または治療した患者を対象. 男性は 122 名, 平均年龄 $72.4 \pm 10.2$ 藏, 超高跉者は, $9.8 \%$. 女性は 127 名, 平均年齢 $77.7 \pm 11.0$ 歳, 85 歳以上は, $25.2 \%$. 合計 249 名. [結果】腷器別では, 胃・十二指腸が 72 例, 大 晹・直腸が 74 例等であった. 重複癌や異時性多発癌が確認された症例は, 計 20 名, 男

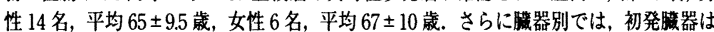

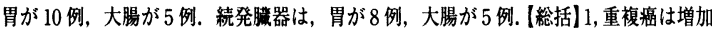
しつつあり，当地域では， $5.6 \%$ 確認された。異時性多発癌は，2.4\%確認された。 2 , 重 複癌は, 初発脿器が胃の症例が半数. 異時性重複癌症例の平均年齢は, 異時性重複癌が 確認された時点で, 平均 67.5 歳であり, 重複癌が確認されない症例の平均 69.1 歳と比 較し，䄪 1.6 歳低く，初発癌が発見された際の平均年龄では平均 4.2 歳低い。高齢化が 進行した地域では，重複堛を念頭に経過観察を行なうことが不可欠である。

PPB-3-022 高度肥満症例の虫垂切除術における皮切の工夫 戸川 剛, 藤山准真, 鈴木源一 （国民健康保険蒲生町病院外科）

【はじめに】虫垂切除術における皮切はMcBurney 点を中心とする交刃切開法や傍腹 直筋切開が代表的であるが, 高度肥满症例においては交叉切開法での術野確保は困藉

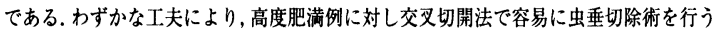
ことができたので, 報告する. (症例) 26 歳女性. 身長 $152 \mathrm{~cm}$, 体重 $85 \mathrm{~kg}$. 下腹媇璧よ り頚側の皮下脂肪を粘着テープにて思いきり左頭㑡へ牽引し手術台に貼付け固定す

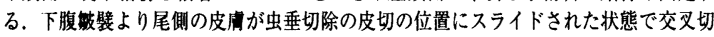
開法にて虫垂切除術を行った. [結果】術野展開は良好であった. [考察]一般に肥満症例

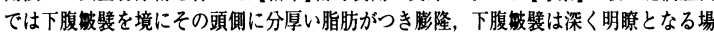
合が多い。一方, 下腹散銥より尾側には比較的脂肪の量が少ない. 通常の虫垂切除の皮 切を置く部位は下腹㿮暜より頭側にあり，特に脂肪の分厚い部分で手術を行うことに なるが, 本法では脂肪の薄い部をスライドさせることにより, 術野を浅くし, 手術を容 易にすることができた.結語】下腹の皮下脂肪を毫引して皮切部をスライドさせるこ とにより，高度肥満例における虫垂切除術を交又切開法で容易に行うことができる。

PPB-3-023 当院における神経筋難病患者に対する消化器外科全身麻 酔手術の検討

佐竹信祐, 三里卓也, 前田裕巳, 宮本良文

(国立療養所兵庫中央病院外科)

[目的] 神経觔勒病患者に対する消化器外科手術の意義や問题点について検討した。 [対象およ び方法了神経筋難病患者に対して行われ大消化器外科全身麻醉手術 25 例，27件を対象とし， 術前評価, 術中因子, 術後合併症, 術後生存率を検討した。[結果]平均年数は 58.8 歳. 手術の

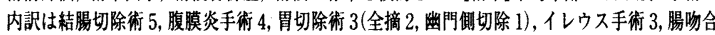

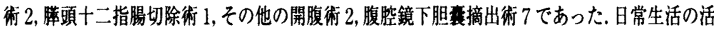
動度は house-bound 4 侧, chair-bound 10 例, bed-bound 11 例. 意思㻋通不能 6 例，経口掑 取不能 9 例 (36\%), 気管切開あり5例 (20\%)，レスピレーター装着 5 例 (20\%) であった。

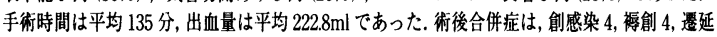
無呼吸 4, イレウス 3 , 肺炎 2 , 胆汁漏 1 , カテーテル敗血症 1 , 悪性症候群 1 , 手術死亡はなかっ た. 全 25 例の術後 5 年生存率は $76.7 \%$ [結語] 1 . 神経筋蜼病患者に対する手術は概权安全に 施行し得た．２．要延無呼吸，漂創，悪性症候群なと神経筋疾患特有の術後合併症には注意が必 要であった．．手術死亡はなく，術後の予後も良好で手術の意義が再確認された。

PPB-3-024 腹部緊急手術における腹腔鏡下手術の役割 安藤秀明, 花岡農夫, 田中雄一, 明石 建, 料山博英, 岩崎 涉, 小林芳生, 大澤岳史

(中通総合病院外科)

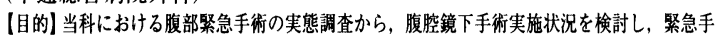
術における腹腔鏡下手術の役割を検討する.【対象】1998年から 2003 年末までの 6 年間に中通

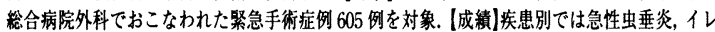
ウス,ヘルニア联頓，上部消化管潰㕠穿孔の㮌で多かった，術式は，虫垂切除，消化管穿孔に

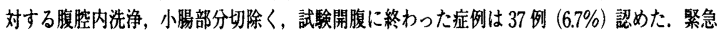
手術のうち腹腹镜下手術は 50 例 $(8.3 \%$ )であった。腹腔镜下手術における合併症はなかった。 年代別変巷をみると, 1998 年加緊急腹腔鏡下手術は $2.1 \%$ 加 2003 年には $17 \%$ と增加し た. 現在は上部消化管穿孔に対する大網充填，洗浄，ドレナージを標準術式としている。腸閉 塞や虫垂炎症例に対しては，1998年では，診断的腹腔鏡として，開腹処置に移行していたが， 現在は鏡梘下に处置をおこなっている. [考察】当科の緊急手術は虫垂切除, 潰場穿孔が多く,

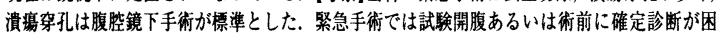
難な症例が少なくなく，緊急腹腔鏡下手術はこれまで以上に応用されるべきと考えた。 
PPB-3-025 ハイリスク症例に対する腹腔鏡下手術の術後成績 長谷部行健"，永澤康滋"，鈴木康司 ${ }^{1}$ ，馬越俊輔"，新井賢一郎"， 大谷忠久",，小池淳一2'，船橋公彦"), 寺本龍生 ${ }^{21}$

(川崎社会保険病院外科 ${ }^{12}$, 東邦大学一般消化器外科 ${ }^{21}$ )

心肺機能低下を伴うハイリスク症例に対する腹腔鏡下手術の術後成績, 安全性について検討し た. (対象と方法) 腹腔鏡下胆䍹摘出術, 総胆管切石術症例 (A 群) 101 例, 大腸切除術症例 (B 群) 30 例. A 群, B 群で心肺機能低下例，機能正常例で背景因子，術後成績を検討した，検討項 目は年秢, 性別, 心肺機能, ASA 分類, 手術時間, 出血量, 合併症, 術後在院日数等. (結果)心 肺機能低下例は A 群 21 例 (20.8\%), B 群 14 例 (46.7\%). A 群譏能低下の内容は心機能低下 3 例，肺機能低下 15 例，心肺機能低下 3 例。平均 $\%$ VC66.5 $\pm 10.0 \%$ ，平均 FEV $1.0 \% 59.5 \pm 3.0 \%$, 平均 $\mathrm{EF} 59.4 \pm 16.9 \%$. B 群機能低下の内容は心機能低下 8 例, 肺機能低下 5 例，心肺機能低下 1

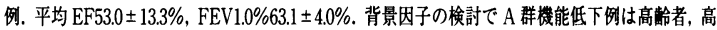
度炎症例, ASA 分類 2,3 症例, B 群は ASA 分類 2,3 症例が多くみられた. 術後成績で A 群機能 低下例に手術時間の延長がみられたが, $\mathrm{A}$ 群，B 群ともに術後在院日数，合併症発生頛度に差は

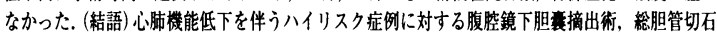
術，大腸切除術の術後成績に機能正常例との差はなく，安全性は確保できると思われた。

PPB-3-026 Stage IV 消化器癌に対する腹腔鏡下手術の経験 田上和夫, 池田泰治, 濱武基陽, 川崎勝已, 橋元宏治, 山岡輝年, 岩谷泰江，是永大輔，竹中賢治 （福岡市民病院外科）

【背景】高度進行消化器癌に対する集学的治療の一環としての外科手術は侵 襲が大きいことがしばしば問題となる.我々は鏡視下手術の低侵謷性に注目 し, 根治の望めない stage IV の胃癌および大腸癌患者に対し, 腹腔鏡下手術 を行い, 後続する治療に成功したので報告する.【症例】(1)幽門狭窄をきたし た進行胃癌に対して腹腔鏡下胃空腸吻合術を行い, 術後早期に化学療法を施 行しえた. (2) 遠隔リンパ節転移が疑われる胃㿋患者に対し, 腹腔鏡下に部分 切除, リンパ節摘出を行い, 進行度を確診した上で術後早期に化学療法を施 行しえた. (3)切除不能の肝転移を伴う進行大腸痹に対し, 腹臆鏡下切除術を 行い, 術後早期に動注リザーバによる動注化学療法または全身化学療法を 行った.【結論】高度進行消化器癌においても, 症例により経口摄取を可能に することによる QOL の向上, および経口化学療法や reduction surgery と しての治療の一環として, 腹腔鏡下手術が有用であると考えられた.

PPB-3-027 Hand Assisted Laparoscopic Surgery (HALS) 症例の検討 伊佐 勉, 岡部安博, 友利寛文, 伊地隆晴, 長菩悦子, 我喜屋亮,

比嘉淳子, 城間 寛

(豊見城中央病院外科)

【目的】これまでに経験したHALS 症例を検討し，その有用性について考察したたので報告す る.【方法】2000年 7 月から 2004 年 1 月までに行った HALS 症例 32 例を対象とした. 術式は, 胃管作成 2 例, 幽門㑡胃切除 3 例, 幽門鍮保存胃切除 1 例, 右側結腸切除 10 例, S 状結腸切除 8 例, 直腸低位前方切除 3 例, 副腎摘出, 勝腫裙核出, 子宮筋腫核出各 1 例，などであった. 術 者は腹胫鏡下胆䡆摘出術およびそれぞれの開腹術式を習得した外科医で計 7 人であった. 各術 式ごとに, 手術時間, 出血量, 術中偶発症, 術後合併症, などを検討した. (成績】開腹術に変更

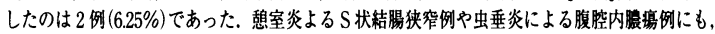
尿管ステントを留置し触診にて尿管を確認しながら安全に切除可能であった. 術中偶発症は 1

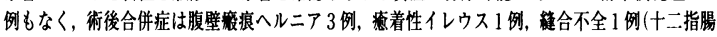

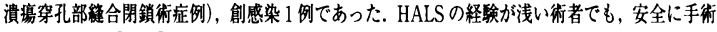
を完遂できた。 [結語]触診や小開腹創からの直視下操作を併用することによって, 比較的安全に 手術が可能であった．また，技術の習得も比較的容易で様々な術式に応用可能であった。

PPB-3-028 腹腔鏡下虫垂切除術の適応と限界について 井上光弘, 木村正美, 堀野 敬, 西村卓祐, 久原浩史, 有馬利明, 上村邦紀

\section{(健康保険人吉総合病院外科)}

【目的】急性虫垂炎に対する腹腔鏡下虫垂切除術（LA）は腹腔内の充分な観察，洗浄が行 之, 創感染も少なく沉発性腹膜炎合併症例等の高度炎症例に対してもよい適応と考える. 当 院では 2000 年 5 月より急性虫垂炎に対し LA を導入し，現在まで小児，全身麻醉不能症例 を除き全例に施行した. 今回LAを完遂できなかった症例を検討し，LAの限界について考 察する. 【対象と方法】 2000 年 5 月より 2003 年 9 月までに LA を行った 32 例につき臨床経 過，手術所見を検討した.【結果】LAを行った 32 例中 27 例が完遂できた（カ夕ル性 2 例， 蜂䆚織炎性 8 例，塤㾴性 17 例，穿孔例 9 例，沉発性腹膜炎合併 4 例)，合併症は晹閍塞 1 例, 術後出血 1 例で遣残脿場や創感染はなかった. 5 例が開腹となったが 2 例は初期の症例

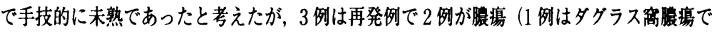
ドレナージの既往, 1 例は数回の憩室脤堭にて保存的加療), 1 例は沉発性腹膜炎の再発で あった. 【結論]LA は炎症の高度な症例であっても初発や経過が短い症例であれば剥離は容 易であるが，以前に高度な炎症の既往がある場合腹腔鏡下での鄎着剥離は困難であった。
PPB-3-029 新型内視鏡ドリップの基碳的検討と試用経験 近藤樹里, 山田英夫, 中島光 $\cdot$, 佐藤雅彦

(東邦大学佐倉病院内視鏡治療センター)

消化管出血に対する止血術および消化管手術前の病変へのマーキンクに内視鏡下ク リッピング術は必要不可欠である、既存の消化器内視鏡用クリッブは鉗子孔からの挿入 は容易で強い把持力があるが、装填は練かい作業で、手袋を装着した手では慣れた者に とっても容易ではない.またクリッブと鉗子との接続に必要な連結版か管哓内に脱落し 鉗子孔から吸引することによりトラフルをおこすことがある. 以上の点を改善した装填 の容易な新型クリッブを試用したので報告する. 新型クリップの材質は既存のものと同

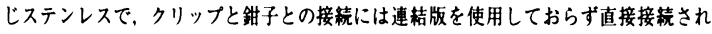
る. 装填については 4 名の被呀者で猐方のクリッフの装填時間を計測した。操作性に関 してはスコープ角度による変化を钼祭した. 把持力についてはフタの切除胃粘漠にク リッフをかけ下方に毫引し,クリッブが外れた時の荷重を測定した. 実除にフタの食道, 胃にクリッピンタを行い,クリッピンクを行った直後と 1 䓢間後で検討した. 新型ク リッフは，既存のクリップと比较して把持力に差を認めず装填が容易であったが、ス コープ反転時の操作においてやや嚾があり今後の改良が必要であると思われた。

PPB-3-030内視鏡外科手術用血管クリップの組織把持力に関する基 礎実験

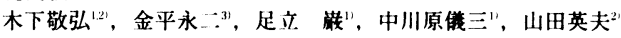

(市立敦賀病院外科", 東邦大学佐会病院消化器センター”,やわたメディ カルセンター ${ }^{3+}$ )

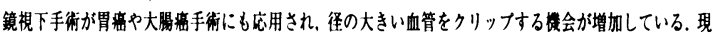
在まで内梘镜外科手衡用クリッフとして、ハンドルを强く握り固定するクラッシュ式が広く使われてき

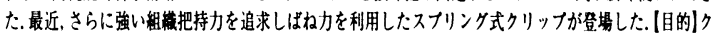

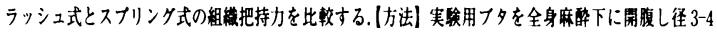
$\mathrm{mm}$ の血管を、クラッシュ式 (C群) (シャフト径 $10 \mathrm{~mm}$ )，スフリンク式 (S 群) (シャフト径 $5 \mathrm{~mm}$ )の

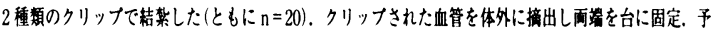
めクリッフに装着された絹系をテンションメーターで事引、クリッブが血管から外れた時点での加重力

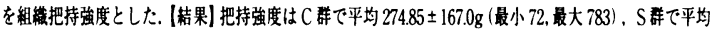

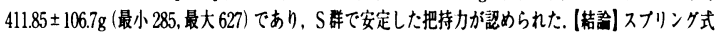
クリッフはより強度な組菕把持力を有していた。従来型クラッシュ式クリッフは把持かにハラつきが生 じることがあり，大きな血管に对してはこれまで通り2-3重にかけるべきである。

PPB-3-031 新しく考案した Sliding Window 用機器とその使用経験 鋤柄 稳, 狩野 契

(シャローム鏩柄医院)

(緒言及び目的) 従来の Sliding Window（以下 SW）法では専用の毫引器の購入を 要することや強い力で旁引した場合，アームが変位しやすいことが課題であった． 今回こうした課題を解決するための SW 機器を試作, 応用した. (对象と方法)試作 した SW 機器の特徽は以下の 4 点である. (1) ケント式军引器が装着可能なアーム （2）アームの変位を防ぐための Deviceの付加（3）アームと患者との距䧺が遠近 2 種類選択可能 (4) アームと患者長軸との角度を自在に変更可能. SW を応用した 10 例の手術別頼度は，幽門㑡胃切 2 , 胃全摘 1 , 分節胃節 1 , 胃切開㪟合止血 1 , 胆 摘+術中造影 2 , 大晹切除 3 である. (結果) 従来の SW 法と同じく.皮切長は胆摘や 胃切開では約 $5 \mathrm{~cm}$, 胃切, 胃全摘, 大腸切除では 8 $10 \mathrm{~cm}$ の切開で十分であった. アームの変位がないため，術野の観察が変位したアームによって妨げられた症例 はなかった，手術時間は，通常開腹例に比して，的 30〜 50\% 延長したか，舟の場 合でも通常開腹時と同等の廊清が可能であった。 (結語) ケント式旁引器が装着可 能な SW 法はミニラパでの手術操作を可能とする有用な方法と思われた.

PPB-3-032 日㷌り腹㓐鏡下胆粪摘出術のクリニカル・パスとその効 果

早田台史, 木島 真, 高橋和裕, 河内 順, 高木睦郎, 安井誠一 (湘南外科グループ茅ヶ崎徳洲会総合病院外科外科)

現在では「日㷌り手術」という言菜も珍しくもなくなってきたが，こと胆石症に対する腹 腔鏡下胆㱏摘出術に対してはまだまだ普及していないというのが現状である.他の庠核 手術や鼠徍ヘルニア手術と比較して，全身麻䣲であること、腹胿鏡ではあるが小開腹にな るため麻㾇性イレゥスを生じること,状況に応して術式が変化することなどから,バリア ンスが多く思い切って施行できないのが現状であろう. 我々湘南外科クルーフ(SSA)は

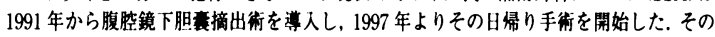
後,様々な試行錯誤を絽り返し、ハリアンスに対応できるための現在使用しているクリ二 カル・パスを完成させた.このバスを用いて茅ヶ㥓德洲会総合病院外科では現在まで篦 行してきたが経過は良好である.パス導入前とバス導入倦の変化について, 日㷌り手術七 ンターのコーデイネーターの意見もふまえてまとめてみたので,これを報告する。患者㑑 へのサービスの改善は明らかではなかったものの，医療提供者傌の仕事のしやすさに関 してはパス導入により改善されており，パスは有奻であると考えられた。 
PPB-3-033 短期入院システムにおけるクリニカルパスの実際と問題 点：小坚と成人鼠烽へルニアでの検討

高橋 篤, 浅尾高行, 加藤公行, 志村龍男, 桑野博行 (群馬大学第 1 外科)

【目的】短期入院システムとクリニカルバスを用いた小児と成人の鼠径へルニア診療におけ る問題点と改善点について検討した。奶象症例と方法] 对象症例は小坚 118 例，成人 73 例である. 小児では一回のバス形式改変を行った。なお, 当科特有のバス診撩として退院翌 日の電話連䊀，日淿り手術の人院前日の電橾連絡を行っている. (結果】パス運用の問題点と して，(1) 小児例で発整や風邪症状のため䄪 $10 \%$ に予定入退院が出来なかった（2）成人例 では街前評便を外来にて詳細に検討する必要があった（3）医療者が交代する場合にシステ 么運用が有機的に行われない事があった。 なお，電話連絡は患者さんの不安解消に有用との 耛果を得ている.【考察】短期入院では街前評価など多くの莱務を外来で行ってその情報を 的確に病棟に伝える必要があり，パス運用には外来と病棟との密接な連㩲が不可欠である. さらに，パス運用の円滑化には医㞠者のバスに対する理解も重要で，医㞠者間の定期的な話 し合いによるパスシステムの再評価と再認驖が必要である.また, 入退院前後の電話による 患者さん評価は特に日㷌り手術例に有用で，患者さん負担の軽娍につながると思われる.

PPB-3-034当科における clinical path の展開と有用性 貝塚広史, 岡田晋吾, 目黑英一, 早川差郎, 入野田崇, 伊藤直子 (函館五稜郭病院外科)

現在は胃、耛腸·直腸、胆不、乳腺、甲状腺，鼠径・大腿ヘルニア，虫垂切除，痔核 の 8 疾患に対し 19 種類のバスを作成, 運用中である.アウトカム・バリアンス用紙を 使用してバリアンスの有無を把暒しており，最終的にはバリアンスと呼べるものは合 併症のみと考える.術後管理・予防抗生珴投与の統一を四ったことによりパス導入前 に比べ 2001 年には使用抗生剂の総量を約半数まで娍少させることができ，またキッ ト製剤比害は 1999 年には $4.9 \%$ であったものが 2002 年には $77.8 \%$ にまで増加，七ー フティマネジメント上も有用であった.点滴・注射類のコスト削減の効果とともに査 定䫫の娍少に晸がり，より適正な医療を提供できるようになった. 2003 年の平均在院 日数は 16.5 日，新入院数，手術数も增加したが, 在院日数の娍少が大きく病床稼㑬率 は低下したため 2003 年 4 月に外科の病床数を 57 床から 48 床にタウンサイジンクし 病床の有効活用を試みている.また今後は栄養不良患者の早期発見・治寮が病院全体 の課題であると考え, NST バス・滇痽バスを使用しチーム活動を活発化し，栄養介入 が在院日数・医療費の娍少に慗がる秸果が得られてきている.

PPB-3-035胃㿋の幽門側田切除術に対するクリニカルパス導入の検 討

黒川 勝, 魚津孝蔵, 遠藤直樹, 天谷 奖, 芝原一慗, 八木真唔, 長谷川洋

(富山赤十字病院外科)

【目的】在院期間の短縮，医療内容の標準化，医療従事者の協調性の向上，患者満足 度の向上，医療コストの軽娍を目的として胃癌に対する幽門㑡胃切除術にクリニカ ルバスを導入した. (対象と方法】平成 15 年 3 月から胃精の幽門例胃切除術にパスを 使用した 38 例 (pass 群) と值前6ヶ月に経験したパスを使用しない36 例 (cotrol

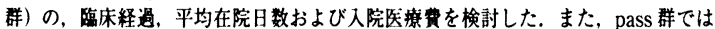
バリアンスの内容について検討した. [桔果]総在院日数は pass 群 18.6 日で, control 群の 24.5 日に比べ有意に短縮した $(p=0.03)$. 入院医撩費においても有意に減少した $(\mathrm{p}=0.02)$. バリアンスは 16 例（負 9 例，正 7 例）にみられた. スタッフ間の連絡不 良からバリアンスを生し反省課題と考えた，患者さんの满足度に対しては概ね良好 であった【結詥】胃密の幽門僋胃切除術に対するパスの導入により，患者さんの満足 度の向上と入院期間の短縮および入院医撩費の娍少に有用であった。

PPB-3-036 胃切除術クリニカルパスの導入と検討

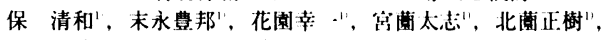

今村 博"，西俣宽人”，爱甲 孝"

(共済会南風病院外科" , 共済会南風病院内科 ${ }^{21}$, 鹿児島大学第 1 外科 ${ }^{31}$ ) 近年,クリニカルパスを迨入する施設が增加し，その有用性に関する理論が確立されてき ている. 特に外科領域においては，術前検査から手術，退院までの一連の流れで, 消化器 内科・麻醉科・外科などの医師だけでなく、病棟・手術室・ICUの看護師や薬凨師，技 師, 栄養士など多種にわたる医療従事者が, クリニカルバスを有効利用することでスムー スな連搭をとりながら医懬を行うことができる，当院では，平成 13 年からクリニカルパ スを採用している.なかでも，外科分野ではクリニカルパス導入の時期が最も早く，また 数も充実している.今回クリニカルパスの有用性を検証するうえで, 当院が施行している 「胃切除術クリニカルパスに関する具体例を提示する. 当院が平成 15 年の一年間に行っ た全身麻醉下胃切除術は108例であった。医師，看護師を中心としたクリニカルパス検討 委員会を中心にハハリアンス症例の検討やオータリンクシステムの導入など,クリニカル パス改正を行ってきた，平均在院日数，医療費削娍の有無や医㞠従事者の意識改革など， クリニカルパスの有用性を検証すると同時に，今後の課題について述べる.
PPB-3-037大腸癌手術症例におけるクリニカルパスの効用と問題点 石光寿幸, 野口 亮, 平木将紹, 谷 博樹, 篠崎由賀里, 酒井 正, 田渕正延, 湯ノ谷誠二

(唐津赤十字病院外科)

【対象および方法】 2001 年 3 月から 2003 年 12 月までの大腸癌手術症例計 95 例 (腹 䏶鏡下手術を含む) を対象とした，CP 導入前症例 (非 CP 群) が 37 例，CP 導入後 症例 (CP 群)が 58 例であり, 各種の臨床項目につき両群を統計学的に比較検討した. 【結果】CP 群は非 CP 群に比し, 在院平均日数が堿少した. ドレーン留置日数, 経口 掑取開始までの日数は有意に減少し $(\mathrm{p}<0.05)$ ，処置および検查でも術後の血液検査 回数およびIVH 施行症例の割合が有意に娍少した. $(p=0.0062,0.0165) \mathrm{CP}$ 群では術 後在院日数におけるバリアンスは $45.9 \%$ に及んだが，そのうち術後化学療法の追加 によるものが $41.1 \%$ ，合併症に起因するものが $58.9 \%$ であった。 ．医療経済的には CP 群では総医療費は減少し，逆に1日あたりの医療費は増加した.【まとめ】 CPは 大腸癌治療の標準化・効率化に一応の成果を上げたと言える，問題点としてバリア ンス発生率が高く, 今回の検討のように術後化学療法の追加などあらかじめ想定さ れるものは，CPに折りこむなどの改訂が必要と考えられた.

PPB-3-038 クリニカルパスに対する医療スタッフの認識（クリニカ ルパス導入の功罪)

木村 知, 大原守貴, 橬井健一, 天野定雄, 柴田昌彦

(日本大学第 1 外科)

(目的) クリニカルパス (CP) はスタッフの理解度が不十分では粗診粗療となる可能性 が危惧される. 今回我々は看護師, 医師の CP 理解度をアンケート調查した. (方法) 対 象は医師 9 名, 病棟看護師 23 名. 質問内容は 1) スタッフ間コミュニケーション変化 2) 患者コミュニケーション変化 3) 診療, 看護の変化 4) 総合評価とした. (結果) 1)，2）ス タッフ間コミュニケーションは $50.0 \%$ ，患者コミュニケーションは $46.9 \%$ が「増えた」 と回答. 3）医師の $55.6 \%$ でアウトカムが認識されていたが「時間的効率化」と答えた 者も $66.7 \%$ であった，看護師では「問題意識を持てる」が $26.1 \%$ に対し「CP患者への 時間を他者に当てる」が $47.8 \%$ であった. 4) 看荽師全員が記録簡略化を長所と挙げ， バリアンス抽出を $52.2 \%$ が負担と答えた。医師は「患者説明に有利」と $66.7 \%$,「診療行 為の制的がある」と $55.6 \%$ が答えた. (考察) 医療者間，患者とのコミュニケーションは 增加したが，時間的効率化や業務軽減が長所として認識され粗診化，省略化が危惧され た. CP本来の意義の認識が不十分であり,これらの周知啓蒙が肝要と考えられた.

PPB-3-039 クリニカルパス

岩間 密, 亀山雅男, 横山恵一, 津田 宏, 北野義德, 藤本喜代成, 中野敬三, 松並展輝

(ベルランド総合病院外科)

【はじめ】医師を含めた多職種参加により作成したクリニカルパス $(\mathrm{CP})$ の有 用性と問題点を明らかにする【方法】鏡視下胆摘（LC），鼠径ヘルニア，急性 虫垂炎，乳癌において，CP 導入前の H.12 年度 (A 群) と H.15 年度 (B 群) の a 入院日数, b 医療費, c 一日単価, dCP 使用率, e バリアンス発生率を比較検 討〔結果】1. LC : A 群 a. 9.5 日 b. 78000 点 c. 8210 点, B 群 a. 6.8 日 b. 43000 点c. 6323 点 d. $95 \%$ e. 18.1\%. 2. 鼠径ヘルニア：A 群 a. 6.0 日 b. 32000 点 c. 5333 点, B 群 a. 3.1 日 b. 31000 点 c. 10000 点 d. $95.5 \%$ e. $33.3 \%$. 3. 急性 虫垂炎：A 群 a. 7.9 日 b. 51000 点 c. 6456 点，B群 a. 6.0 日 b. 37000 点 c. 6167 点 d. $85.7 \%$ e. $41.5 \%$. 4. 乳癌: A 群 a. 21.1 日 b. 98000 点 c. 4545 点, B 群 a. 15 日 b. 95000 点 c. 6333 点 d. $81.3 \%$ e. $38.5 \%$.【考察】CPの導入によ ク，全疾患において入院期間の短縮は認められたが，医療費に関しては必ずし も削減を認めない疾患もあり，一日入院単価についても上下動がみられた。

PPB-3-040大侵熟手術・重症合併症症例に対する医療安全に重点を 置いたクリニカルパス作製

亘野元喜, 筒井理仁, 伊藤達雄, 露木 茂, 植田充宏, 島袋 隆, 坂田晃一朗, 西澤弘泰, 福山訓生

(社会保険小倉記念病院外科)

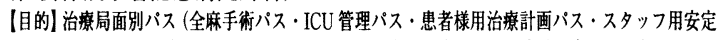
期指示パス)が大侵襲手術・重症合併症症例に適用可能かどうか，医療事故の多い周術期に，パス が医縻の質の管理に奇与するかどうかを明らかとする.【方法】治療局面別パス使用前後のバリア ンス，医縻ミス・ニアミスの発生類度，医療スタッフの医療事故に対する意識の変化等を検討す る. (成繶)バリアンス発生・除外症例は僅かで, パス使用前に発生した, ミス・ニアミスは, パス 使用後には発生しなかった。た，一つ一つのチェック項目・観察ポイントに対する認識が新たと

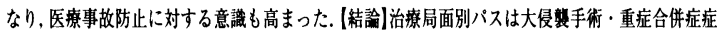
例にも暗用可能と判断された, パス上に記载された各チェック項目・镜察ポイントは，周術期管理 の標準化をめざして選択したが，いづれも医療事故を回避する上でも重要なもので, 今回パス使用 後には，医榇ミス・ニアミスの発生を見なかった。クリニカルパスによる医療の標準化は，周術期 管理においても医療事故を防止し，医療の質の管理に大いに寄与するものと考えられた。 
PPB-3-041 消化器外科領域におけるクリニカルパスの臨床効果〜释 営から見たクリニカルパス導入の功罪

長谷川慎一1.21, 山本裕司", 安藤耕平"1, 正津晶子", 石和直樹",

吉川貴已", 森永聡一郎", 野口芳一", 今田敏夫 ${ }^{3 !}$

(横浜市立港湾病院外科1), 横浜市立大学総合外科 ${ }^{21}$, 横浜市立大学消化器 病センター $\left.{ }^{3 \prime}\right)$

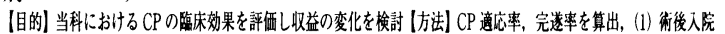

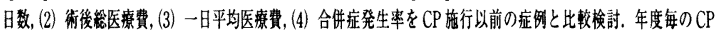

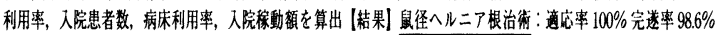

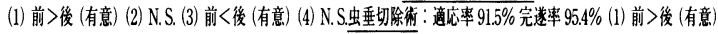

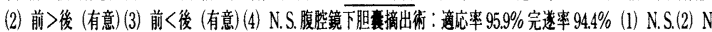

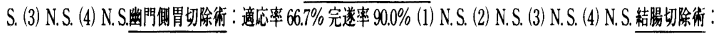

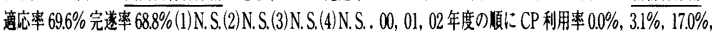

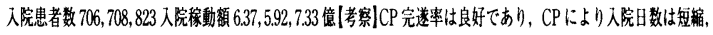

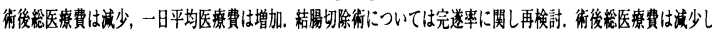

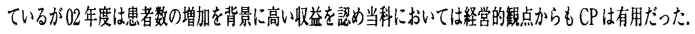

PPB-3-042 記録の効率化をめざしてーオールインワンパス導入の効 果-

山田哲司, 俵矢香苗, 村上 望, 伴登宏行, 森田克哉, 小泉博志, 吉野裕司, 藤森英希, 中田浩一, 小竹優範

(石川県立中央病院一般消化器外科)

平成 13 年よりパス Aの運用を開始した。このパスにより，業務の效率化および在院日数の㮩縮 は图れた。しかし記睩の効率化という新たな問題点を解決するため現在新たな Bのパスを使用し

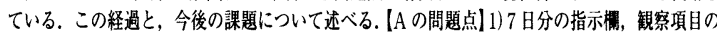
記载樗がまとまっているが, 字が小さ〈記入しづらい2）鹳察項目に対する䛨価基準が不明確 3) アウトカムの棓価が不明確4) 手術室, 回復室, 病棟で異なる記録用紙を使用し, 重複が多い5 栄養師, 薬剂師, PT との連携が不十分である [Bの改善点]記録と指示が一体化した「オールイ ンワンパス」を導入した。急性期にはスペースを多くさき，読みやすくしたまた関保部門の看

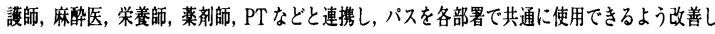
た、アウトカムを見直し，対応した篗察項目の設定，評洒基準の明確化をはかり，バリアンス分 析に供するためのバリアンスシートを作成した【結果】パスの改訂により，記録時間が㓋縮し， アウトカムの評価が正しくなされるようになり，医療從事者間での意思の統一が図れた。

PPB-3-043 クリニカルパスと電子カルテーバリアンス分析における 電子カルテの有用性と限界一

針原 康, 奈良智之, 野家 環, 伊藤 契, 古嶋 熹, 小西敏郎 (NTT 東日本関東病院外科)

（はじめに）導入後 3 年経過した電子カルテ版パスの有用性と問題点について報告する. (電子カルテ版パス)当院では, アウトカムを評価して, 次のステップに進むというコンセ プトの下で, 1 日ごとのオータリング方式を採用した. 導入により，1）電子カルテの情報 の迅速な伝達と共有化がいかされ，チーム医療はより充実することになった，2）必要な オーダーを過不足なく, 迅速に行うことが可能となり，人力に要する時間が大幅に短縮さ れた (胆襄摘除術の場合で $21.6 \pm 1.7$ 分 vs $3.8 \pm 0.58$ 分, $\mathrm{p}=0.0008) ， 3$ ) 診療内容の細部に 至るまで完全に統一され，標準化されることになった（バリアンス分析）当院のシステム ではパスで計画された内容と異なる診療行為にはすべて青 Vマークが表示される. 青 V マークの中で, 在院日数に変動を与える要因となったものはその原因を紐分類して登録す ると, 真のバリアンス (赤Vマーク) となる. 赤Vマークは集計可能である. 症例の調査 では電子カルテの長所が発揮され, 院内のどこにいても必要なデー夕はすべて収集可能で ある.(おわりに) 電子カルテ版パスはわが国の医療改革に大きく貢献すると思われる.

PPB-3-044 腪頭十二指腸切除術後バリアンス解析に基づくアウトカ ムマネジメントの効果 袴田健一, 青木計績, 原豊, 吉田 淳, 十束英志, 豊木嘉一, 鳴海俊治, 吉原秀一, 佐々木睦男

(弘前大学第 2 外科)

【目的】バリアンス解析に基づく满頭十二指腸切除術後クリニカルパス改訂の効果について 検討する. 【対象】 2000 年 10 月以降の 76 例を対象に，パス導入前 (I期, 14 例)，導入後 (II 期，34), パス改訂・術式変更後 (III 期, 16), 再改訂後 (IV 期, 12)の臨床的丁ウトカムの 推移を検討した. III 期以降は PpPD-IIA-1 (前結腸性)を原則とし, バリアンス管理法を一 定とした. IV 期は食事開始時期を早め, 硬膜外麻椠ならびに中心静脈栄養を原則不採用とし た.【結果】術後在院日数はI期 $40 \pm 14$ 日, II 期 $34 \pm 15$ 日, III・IV 期 $24 \pm 6$ 日(バリアンス 非発生例 I期 $31 \pm 6$ 日, II 期 $27 \pm 9$ 日, III 期 $21 \pm 2$ 日, IV 期 $20 \pm 3$ 日, 発生例 I 期 $48 \pm 14$ 日，II 期 $41 \pm 17$ 日，III 期 $27 \pm 7$ 日，IV 期 $32 \pm 7$ 日）と，III 期以降有意に減少し，標準偏差 值も娍少した。この間のバリアンス発生頻度に有意な変化はなかった.【結詇】アウトカム評 価に基づくパスの改訂は,バリアンス発生の有無にかかわらず PD 術後在院期間を有意に娍 少させた. また, バリアンス治療の標準化により術後在院期間のばらつきが減少した.
PPB-3-045 膁䫒十一指腸切除後の短期合併症の評価 世古山英, 梛野正人, 湯浅典博, 小出高问, 新井利幸, 江烟智希, 三村雄次

(名古屋大学大学院器官調節外科)

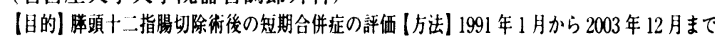

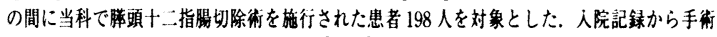
術式, 合併症, 在院期間などを調査した. 【結果】198 例の平均手術時間は 9 時間 11 分, 出血量 は $1605 \mathrm{ml}$ であった. 198 人中 67 例に㿽血を必要とした. 1 名 $(0.5 \%)$ のみが感染源不明の

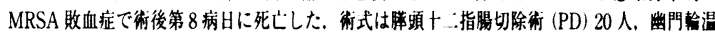
存滕頭十二指晹切除術 (PPPD) 111 人, 要全胃温存腾䫓十二指晹切除術 (SSPPD) 67 人であっ た. 全体での合併症䍜患率は 198 人中 110 人 $(55.6 \%)$ で，それぞれの術式ごとでは PD 14 人 $(70.0 \%) ， \operatorname{PPPD} 58$ 人 $(52.5 \%) ， \operatorname{SSPPD} 36$ 人 $(53.7 \%)$ であった. 主な合併症は勝空腸䋖 合不全 64 人 $(32.3 \%)$ ，創感染 49 人 $(24.7 \%)$ ，腹峔内出血 6 人 $(3.0 \%)$ であった. 腹榺内出 血に对しては 5 例が TAE, 1 例が保存的亦法で対処さ九，全例教命し得た. 平均術後在院期間

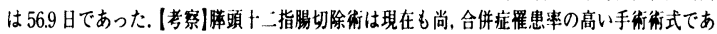
るが、当科での手術関連死亡率は $0.5 \%$ であり，比较的安全な術式となったと考えられた。

PPB-3-046 クローン病に対する当科の治㟫戦略

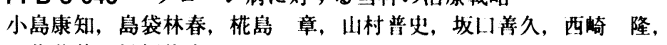

田代英哉, 松圾俊光

(松山赤十字病院外科)

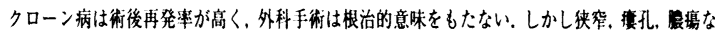
と外科的治療を要する症例も少なくない，今回当科におけるクローン病の外科的治療成绩を検 討したので報告する. [対象] 1995 年から 2003 年 12 月まで当科で維駼したクローン病開腹手衙 症例 31 例（総手術数 34 回）を対象とした。[結果]男女比は $22: 9$, 初回手術時平均年龄は 35.5

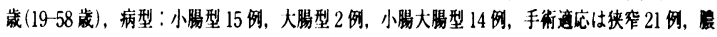

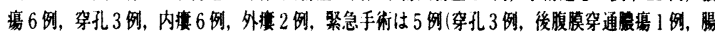

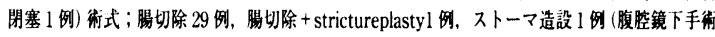

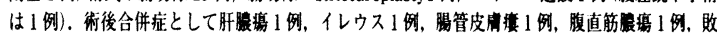

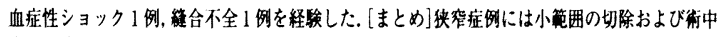

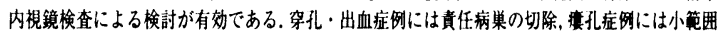

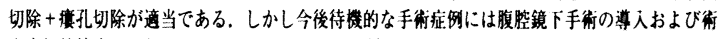
中内視鏡検査により poly surgery の回避および低侵能化をはかるべきである.

PPB-3-047 肝胆䐙悪性疾患手術における貯血式自己血輸血の経験

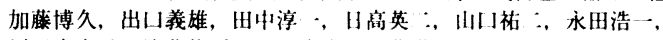
辰川責志子, 遠藤俊吾, 石田文生, 工藤進英

(昭和大学横浜市北部病院消化器センター)

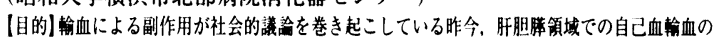

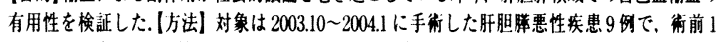
䓢間までに眝血した，㻌血開始基㴖を $\mathrm{Hb} 8 \mathrm{~g} / \mathrm{dl}$ と設定し許容出血量を算出，有奻貯血量=眝血

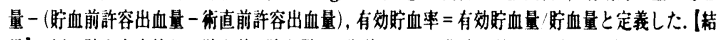
果】5 例で貯血を実施し，眝血前 (貯血群)・術前 2 週間 (非眝血群)の許容出血量は $1534 \pm 288$

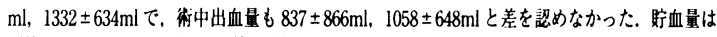
平均 $982 \pm 278 \mathrm{ml}$ で, 1 例で问種血追加を要した，非貯血 4 例は感染 $2 \cdot$ 筫血 $1 \cdot$ 期間不足 $2 \cdot$ 遠 方 1 に起因 (重複有)し，3例で问種血㢵血を要した，販血群全例で，貯血により術直前までに $\mathrm{Hb}(1.3 \pm 0.9 \mathrm{~g} / \mathrm{dl})$ ·許容出血量 $(287 \pm 244 \mathrm{ml})$ ともに, 非眝血群の変動に比して有意に低下

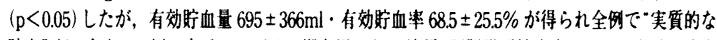

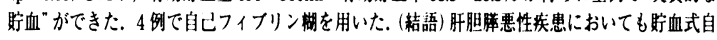

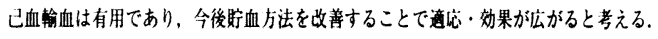

PPB-3-048 胃癌, 大腸湦における化学撩法の臨休治験推進のための 問題点

軍司祥雄, 鍋谷主宏, 林 秀樹, 耍崎信一, 松卜一之, 牧野治文, 宮内英聡, 青林泰斗, 望月克鿆, 落合武德

(千葉大学大学院先端心用外科学)

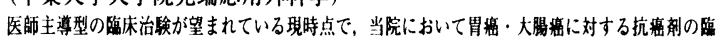

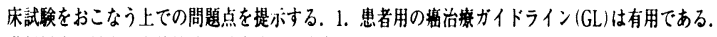
進行胃癌に対する術後補助化学療法は，䧗床研究としての治港法の位置つけにあることがGLの 中に明記されてあり，患者・医師とも化学繁法の意義を理解するのに，有用である. 2. 単䖵施設で

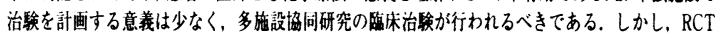
に対する拒否反応なとがあり，烸床治涘参加への敬蒙の必要性が望まれる.3.チーム医療の必要性

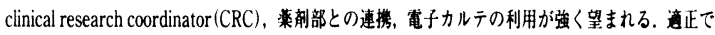

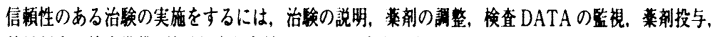
効果判定の検査準備，効果判定と多故にわたる代事を数密におこなうことが要求されており。診康

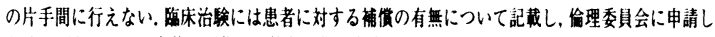

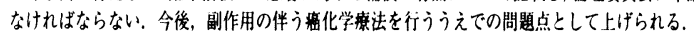


PPB-3-049 特異な臨床像を示したGIST の 3 症例

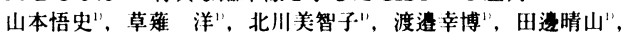

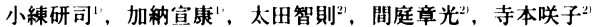
(亀田総合病院外科 ${ }^{12}$, 亀田総合病院泌尿器科" 特異な湢床像を呈したGIST の 3 症例を報告する. (症例 1) 60 歲女性. 息子 3 人に皮 庙所見としての家族歴を有する von Recklinghausen 病の患者. 左褐色紐胞腫の診断

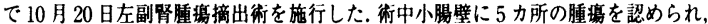
病理訩断では GIST であった。 [症例 2]67藏女性. 家族歴はないが 0 荿から cafe'-au

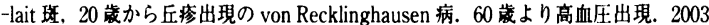
年 9 月,璃梗塞となったが保存的に改善. 腹部面像診断で両㑡副堅腫堭を指摘され两

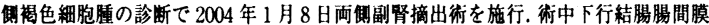

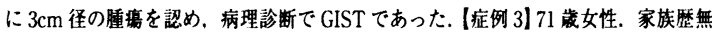
し. 集団健診で異常を指摘. 2003 年 12 月 2 日胃部分切除術施行. 術前診断された以

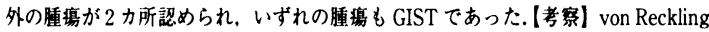
hausen 病と GIST との合併は報告があるが，さらに褐色紐胞腫との合併は極めて希 である。また，胃の多発 GIST は本邦で数例が報告されている。

PPB-3-050 術後 5 年以上経過ののち肝転移を生じた GIST の 2 例

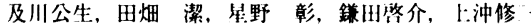

(岩手県立北上病院外科)

消化管粘膜下腄場術後，5年以上経過の後，肝腄場を指摘され，GIST 肝転移と診断され

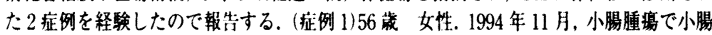
部分切除術を施行. 長径 $11 \mathrm{~cm}$, 重量 640g. 形態学的に Leiomyoma と診断. Mitosis は

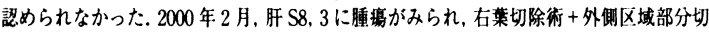
除街を施行. CD34 (-), c-kit (+), s100 (+), SMA (-), desmin (-) でGIST

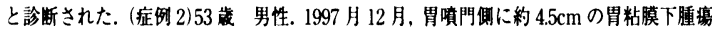
が認められ，腹跀鏡下胃部分切除術を施行. 形態学的にSchwannoma と診断. Mitosis は 3-5 10 (HPF) であった. 2003 年 11 月, 閉塞性黄疸で精查. 下部胆管曐と診断され たが、肝 S4にも腫瓷を指摘された。幽門㭘温存䐙頭十二指腸切除術十肝左葉切除術を施

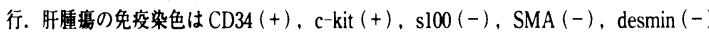
でGIST と診断された，現在 GIST は病因，転移形態，危険因子，菜物㙩法等の解明がす

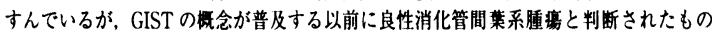
で，街後 5 年以上経通した後での再発もみられ，長期的観察が重要と考えられた。

PPB-3-051 胆衰摘出術後に発生した乳糜腹水に対し腹腔静脈シャン トを施行した 1 例

浅間俊之"，海老沢良昭"，葛西真一"，長谷部千登美"，吉田 威 (旭川医科大学第 2 外科”, 慶友会吉田病院肝戥病七ンター 肝硬変を合併した胆石症に対して胆㱏摘出術を施行し，術後に乳糜腹水が発生した症 例に対して, 腹腔竫脈シャントを留犆し良好な䊅果が得られたので報告する。患者は 67 歳，男性. 平成 14 年 2 月頃より時折の腹有出現. 同年 2 月他院受診し胆石症及びC 型肝硬変をの診断となった。開腹胆嚄摘除術を施行されたが,術後4ヶ月ほどで腹部膨 满，倦总感，下肢浮隀が出現し，画像上，腹水の出現を認めた。保存治撩を行い改善增 悪を綝り返していたが, 平成 15 年 2 月頃より腹水の增強を認めたため, 肝硬変に伴う

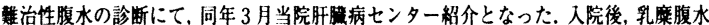

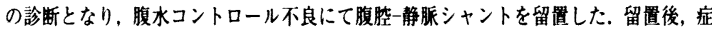
状の改善をみており，術後７ヶ月にて腹水はほは消失している。本症例は, 肝硬変の程

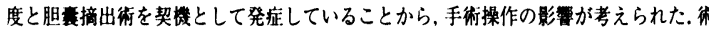

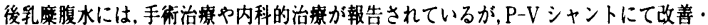
治密した報告は無く，有効な治膫の一つとなりうることが示唆された。

PPB-3-052 膡頭十二指晹切除術を要した十二指腸腸間膜線維腫症の 一例

岡田克也, 宮澤光男, 鳥井孝宏, 利光靖子, 俵 英之, 小澤修太郎, 小川展二, 松本 隆, 篠㙇 望, 小川 勇

(埼玉医科大学消化器・--般外科 (I) )

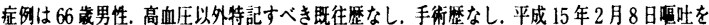

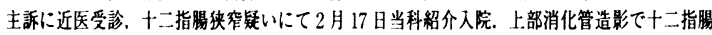
2nd portion から 3rd portionにかけて侠窄あり，上部内視镜検査では同部位の erosiveな変化 を認めた. CT 上膁鈎部付近に軽度造影奻果の認められる隀萑影と十二指腸 2nd portionから

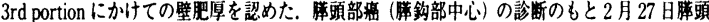

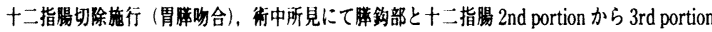

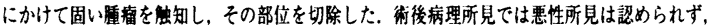

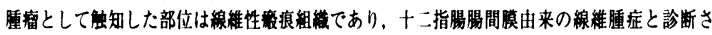

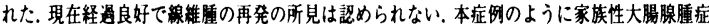

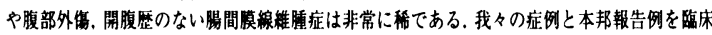

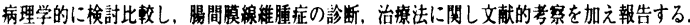

PPB-3-053茀頭十二指腸切除術後に発症した“たこつほ型心筋症”の 1 例 首藤恭広, 森本芳和, 田中康博, 青野豊一, 中井澄雄, 山本重孝, 小川達司，栗原陽次郎，西川和宏，吉田卓矢 (大阪府立病院消化器一般外科)

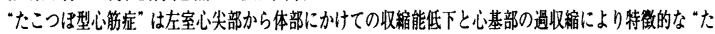

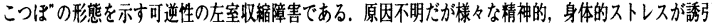
として指摘される。今回，胆管癌術後の橉胃吻合部滰瓷出血が生したため施行した緊急手術直後に゙たこ

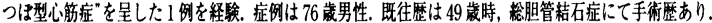

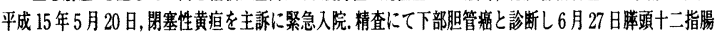

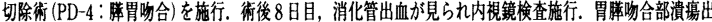

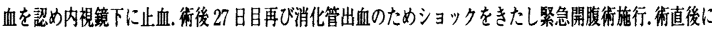

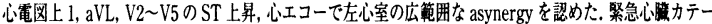

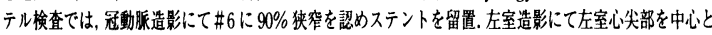

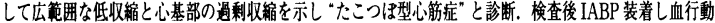

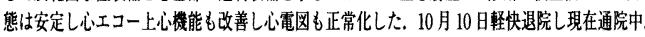

PPB-3-054 開腹手術に関連して発症したタコッボ型心筋症の 3 例 安岡康夫 ${ }^{1.2}$, 吉田 敦", 山本泰三", 中川秀和 ${ }^{21}$, 雁木淳一" (済生会松山病院外科", 公立周桑病院外科 ${ }^{2}$ ) たこつほ型心筋症は心筋梗塞と類似した臨床経過, 心電困変化を有し概して, 予後は比 較的良好であるとされている.ただし重症心不全や心原性ショックを合併する症例も存 在し，全例が予後良好であるとは言い難い、今回我々は開腹手術に関連してタコツボ型 心箭症を発症した 3 例を経験したので報告する。症例 1 は 75 藏男性 胆石術後, 腹壁離 開し再手術施行. 術翌日胸部症状はなかったが, 心電图上, 胸部誘導にて ST-T 上昇を 認めた，心筋梗塞を疑い，心腈カテーテル検查を施行したが，冠動脈に有意㹨害は認め なかった。症例 2 は 76 歳男性, S 状結腸癌穿孔による沉発性腹膜炎にて, ハルトマン手 術施行. 術直後 shor RUNをきたし，電気的徐細動を行った，心電図上，胸部誘導にて ST-T 上昇を認め，緊急心櫵カテーテル検査を施行. タコツボ型壁運動異常を認めたが，

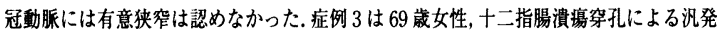
性腹膜炎にて, 手術を行った。術翌日心不全症状が出現. 血清トロポニン迅速検査は陽 性. 心電図上 ST-T 上畕を認めた。後日心滕カテーテル検査を行ったが冠動脈に有意狭 窄は認めなかった，以上 3 例について若干の検討を加えたので報告する。

PPB-3-055 門脈ガス血症の 5 例と本邦報告例 108 例の検討 〜緊急 開腹術か? 保存療法か? ?

新関浩人, 加藤健太郎, 矢野智之, 安保義巷, 中村文隆, 成田吉明, 道家 充, 增田知重, 岸田明博, 樫村暢一

(手稻溪仁会病院外科)

【はじめに】門㟲ガス血症は，腸管壊死などに伴う予後不良の兆侯とされてきた。自験例 5 例と本 邦報告例 108 例の治療方針を検討した. (門腺ガス血症の自験例)症例 1：一過性型虚血性大腸炎で

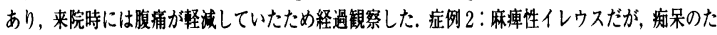

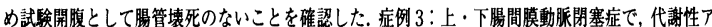

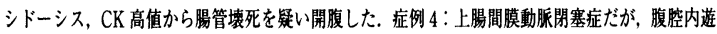

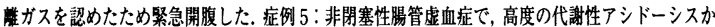
ら腸管壊死を疑い開腹した. [本邦報告例] 本邦報告例 108 例を開腹必要群 81 例と不要群 27 例に 分類し，比較した，開腹必要例て，筋性防御あり，CRP 高值，代謝性アシドーシスの症例が多かっ たが，特異所見はなかった。 [考察]門脈ガス血症の原因疾患は多彩である。外科治療を要する症例

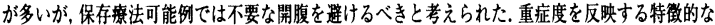
所見はないが，能性防御の有無，CRP 值，Base excess值が参考になると考えられた。

\section{PPB-3-056 残胃及び大腸の同時多発性 signet-ring cell carcinoma $の$} 一例

岡部安博, 伊佐 勉, 友利寛文, 長菩悦子, 伊地隆晴, 我喜屋亮, 比嘉淳子，城間 寬

(豊見城中央病院外科)

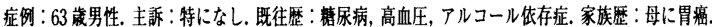
現病歴：2001年11月，他院にて幽門倒胃切除術を受けた、病理学的には muc ( + signet), mp, inf $\beta$,

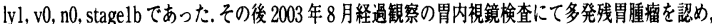
生検では signet-ring cell ca. であった. また術前の大腸内梘镜検查にて上行結腸に多発性ポリーフを 認め，生検にて signet-ring cell ca. であった，残胃及び上行結腸の同時多発性 signet-ring cell ca.

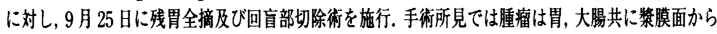

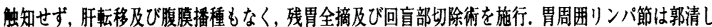

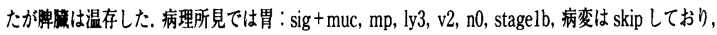
胃壁内に多発し，食道にも浸淍あり，大腸： signet-ring cell ca．で，m，sm 病変が多発。リン八゚節 2 群轻移陽性で stage3aであった。このような胃およひ大大腸の同時多発性 signet-ring cell carcinoma は検索した限りでは他になく，非常に稀な症例であるため経過も含め報告する。 
PPB-3-057副甲状腺腫場を合併した家族性大腸ポリポーシスの 1 家 系 河野文彰, 関屋 亮, 篠原立大, 内野広文, 児玉英之, 中村都英, 松崎泰憲, 鬼塚敏男

(宮崎大学第 2 外科)

【绪言】家柣性大腸ポリポーシス(FAP)は消化管に多発性ポリーフををきたす遺伝性疾患である，また種々 の消化管外病変をきたすことが知られているが, 副甲状腺病変との合併列の報告は少ない, 今回は副甲状

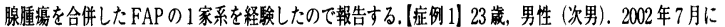
FAP (母, 叔母もFAP と診断)の診断にて, 大腸全摘術，回腸・肛門管吻合術が施行された，術後さら

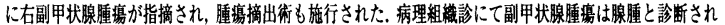
た. [症例2] 28 歳, 男性 (長男)。2003 年7月にFAP及びCrohn 病と診断され当科入院となった。 また

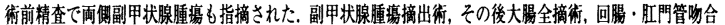
術が施行された、病理組維診にて副甲状腺腫場は腺腫と診断された。症例3] 24歳, 女性 (辰女). 1998

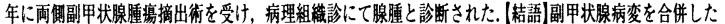
FAPの報告はまれで，過去に1報告があるにすぎない.しかし今回の1家系においては偶発的に生したと は考えにくく，副甲状腺も他の組織と同粎に何らかの腫韵化が生じることが示唆された。

PPB-3-058 肝腫瘍との籃別が困難であった腹腔内遊離体の1例 山口钽之", 橋本晋一", 小松信男", 高田 学", 安藤豪隆", 荻原裕明"，臼井健二"1"，小山正道 ${ }^{21}$

(小諸厚生総合病院外科 ${ }^{11}$, 小諸厚生総合病院病理診断科 ${ }^{21}$ ) 症例は 71 歳, 男性. 1 年前, 肺癌のため右肺上葉切除術を受けた既往がある. 全身検索 目的で腹部エコー・CT を行ったところ肝 S6 表面に腫瘤が認められた. 原発性または転 移性の肝腫場が疑われ, 腫嘴が肝表面に存在することから腹䏶鏡下に手術を行った. 肝結

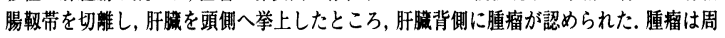
囲組織と結合織により固定されていたがこれらを切離することで容易に摘出された。腫 瘤は $30 \mathrm{~mm} \times 25 \mathrm{~mm} \times 16 \mathrm{~mm}$, 重量 $10 \mathrm{~g}$. 表面平滑で光沢あり, 乳白色を呈していた. 組 織学的には，脂肪組織であったと推定される壊死組織の周囲を硝子化した樴維状組織が 取り囲んでおり腹脘内遊離体と診断された．腹腔内遊離体が肝表面に固定されている場 合, 画像所見上転移性あるいは原発性の肝腫瘍との筐別が困難である場合が多い，肝表面 にエコー上 hypoechoic, CT 上低吸収, MRI 上 T1T2 強調像とも低〜中等度信号を呈す る境界明瞭な腫智を認めた場合には锤別診断として腹腔内遊離体も念頭に置き，観察可 能な部位であれば腹腔鏡下にアプローチするのも有用な方法であると思われた。

PPB-3-059大腸内視鏡の前処置後に急激に発症した直腸痹による閉 塞性大腸炎の一例

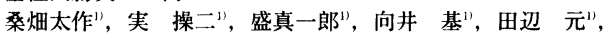
爱甲 孝 ${ }^{2}$

(阿久根市民病院消化器病センター", 鹿児島大学第 1 外科 ${ }^{21}$ )

閉塞性大腸炎は大腸に何らかの閉塞機転が存在し，その口溉に非特異的な炎症をみとめる病変として 知られている. 今回 CFの前処置後急激に発症した直腸痹による閉塞性大腸炎を経験したので報告す る. 症例は 82 歳の女性. CF のため前処置施行，その後から腹満訴之胆汁梯呵吐認めた，CFにて3/ 4 周性の type3 直腸癌を認めた。鏡体通過可能であり, 肛門よりイレウスチューフを留置した. 当日夜 より熱発出現，腹部は defence 様となったため，緊急開腹手術を施行した，開腹すると混摆した黄色腹 水を認め，穿孔部位は認めなかった. Hartmann 手術を行い, 腸管粘膜の壊死所見を認めたため, 横行 結腸にて人工肛門を作成した，切除標本では下行結腸より横行結腸にかけて結腸ひもに汾う維走潰場 を認め，粘膜は壊死していた，閉塞性大腸炎の原因として晹管内压上昇による粘膜の虚血，晹管痤萃 による血流障害，腸管内練菌感染等が挙げられるが，本症例ではCF 前处置による腸管内压の上昇に 伴って, 粘膜の虚血あるいは腸管の㘘縮をおこし急激に閉塞性大腸炎が発症したと考えられた。閉塞 を認めない直腸癌症例でも CF 前処置により閉塞性大腸炎をきたすことがあり留意する必要がある。

PPB-3-060 26 年後に骨盤内再発し膀胱, 直腸合併切除を要した子宮 原発 hemangiopericytoma の 1 例

伊澤 光, 相馬逸郎, 林 伸泰, 福地成晃, 吉田哲也, 戎井 力,

先田 功, 蓮池康德, 藤本高義

(兵庫県立西宮病院外科)

(緒言) hemangiopericytoma は毛細血管構成細胞の一つである pericyte に由来するまれな 腫瘍である. 今回， 26 年後に骨盤内再発をきたし膀胱，直腸合併切除を要した子宫原発 hemangiopericytoma の 1 例を経験し報告する. (症例) 症例は 60 歳, 女性. 1977 年子宮原発 hemangiopericytomaに対して子宮付属器切除および術後放射線治療を施行された. 2002 年1月便潜血陽性の精査目的で当院を受診した. 注晹造影検查では S 状結晹に隆起型陰影

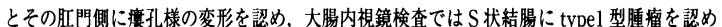
たが生検では炎症性変化のみであった. 造影 CT 検査ではダグラス窝に膀胱浸润を疑う長径 約 $4 \mathrm{~cm}$ の不正形腫㿔認めた，確定診断を得られないまま 2002 年 3 月 4 日開腹術を施行し

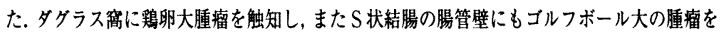
認めた，一部膀羘とともに低位前方切除術を施行し腫瘤を摘出した。病理組織学的にはいず れの腄㢖も hemangiopericytoma であり，26年後の再発であることが確認された.
PPB-3-061 原発部位.不明の巨大腹部腺總の一例

山下晋也, 藤谷和正, 平尾素宏, 增田慎三，柏崎泟樹, 池永雅一, 武田 裕, 三䲴秀行, 沢村敏郎, 辻仲利政

(国立病院大阪医療センター外科)

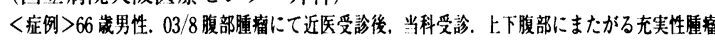
を触知．AFP，CEAの著明な上昇あり，術前 MRI：肝下枟から骨盤上部に至る内部に一部出

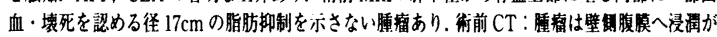

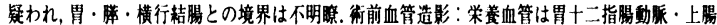

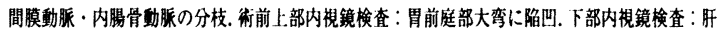

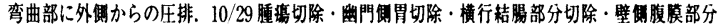

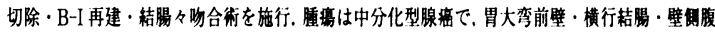

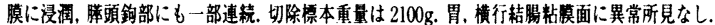

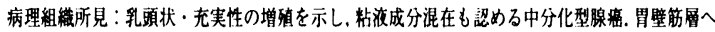

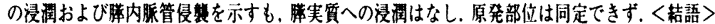
最終病理診断に至っても原発部位が同定できない原発巢不明湾 (occult primary malignancy) の 一例を経呀した，原発巣不明繁について若干の文献的考繁を加え報告する。

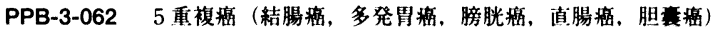
の 1 例

藤岡雅子，五井孝憲，村上，真，廣野靖夫，前田浩幸，石田陚， 木村俊久, 飯田 敦, 片山宽次, 山上明夫 (福井大学第 1 外科)

【はじめに】近年画像診断の進歩による早期診断や、各種穜の治療成綪の向上に伴 い, いわゆる重複㾇の報告が增加している。合回我々は多発胃艘を含む 5 重複癌症 例を経験したので報告する。【症例】66歳，男性．家族歴として母に食道癌，弟。妹

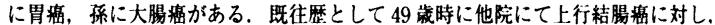
右半結腸切除術を施行されている(第 1 癌). 66 歳時, 食道浸潤を伴う噴門部胃癌 (Borrmann2) および州門部胃㿋（Borrmann2）の診断で势全摘，下部食道切除術

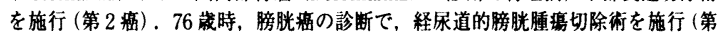

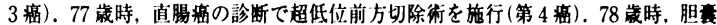

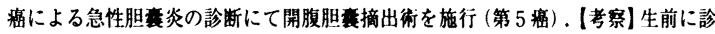
断, 治療された 5 重複癌の本邦報告例は少ない. 本症例は同時性多発胃痻を含む異

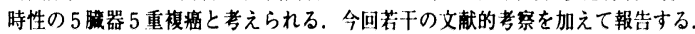

PPB-3-063 下大静脈原発平滑筋肉腫の一切除例

端本昌夫"，大場範行"，瀬F门智彦"，柏原秀史"，高木正和"， 中上和彦"，伊関丈治1"，遠儿和成 ${ }^{2.21}$ ，松田捷彦 ${ }^{2}$ ，新井一守 ${ }^{3}$ (静岡県立総合病院外科 ${ }^{2}$, 静岡県立総合病院心脿血管外科 ${ }^{2}$, 静岡県立総 合病院病理検查科 ${ }^{3}$ )

症例は 74 藏，女性. 両下肢のむくみ下半身の倦急感，息切れ自覚して近医受診. 腹部超音

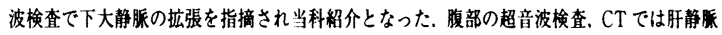
合流部直下から総腸骨静腺分部部直上まで長径 $16 \mathrm{~cm}$ にわたり下大静腺内に低エコーな, 造

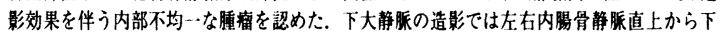
大静脈は造影されず奇静腺，半奇静腺，脊椎静脈を介して上行していた，血管造影やその他 の検査で、肝, 腎、副腎に原発の病変は認めなかった. 以上より下大静腺原発平滑笳肉腫の

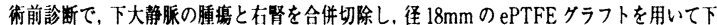

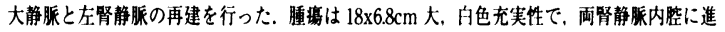

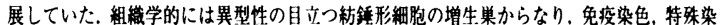
色から平滑筋肉腫と診断した，現在術後5 个月経過し，再建血管の閉塞，再発等認めていな い，下大静脈原発平滑筋肉腫は比較的稀であり，貫重な症例と考えられ，報告する.

PPB-3-064 周術期に血球食食症候群をきたした 2 症例

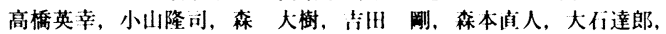
北出貴嗣，梅木雅彦，栗栖 茂，漬田 信

(兵庫県立淡路病院外科)

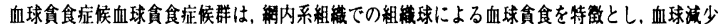
など多彩な臨床症状を呈し重篤な転㷌をとる疾患であるが、胃票が原因との報告は少ない，胃

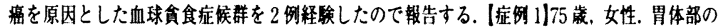

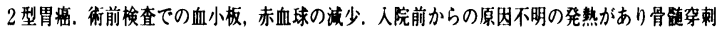
を行った結果，血球食食の所見が認められた、ステロイドバルス撩法を行った秸果，血小板の

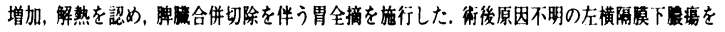
合併し，術後 4 日目に呼吸不全. 術後 5 日目にはショックから心停止となり，術後6日目に死

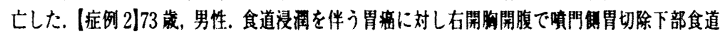
合併切除術施行．術後，讙蔒性肺炎を合併したが軽快，第 80 病日頃より沉血球娍少が出現.

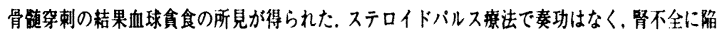
り第 110 病日死亡した.|まとめ消化器雷術前後においても原因不明の血球少は本症も念

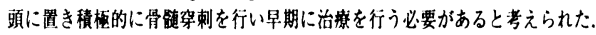


PPB-3-065 浸潤性羘管㿋・滕等内乳頭腫場における CD10 間質発現 の意義

矢田一宏"2”, 平野誠太郎", 岩下幸雄", 甲斐成一郎", 柴田浩平",

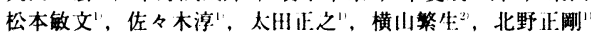

(大分大学第 1 外科", 大分大学第 1 病理")

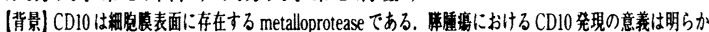

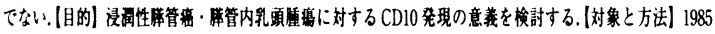

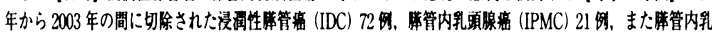

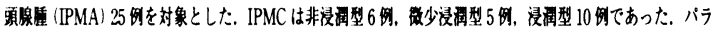

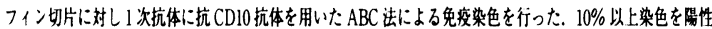

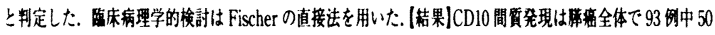

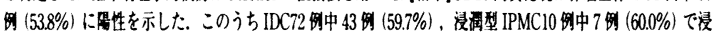

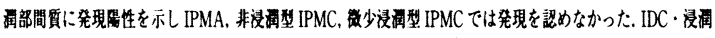

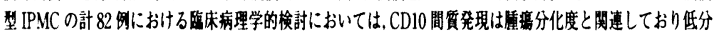

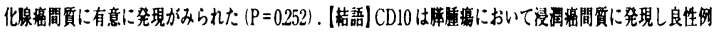

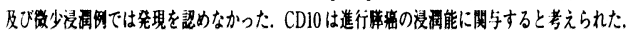

PPB-3-066 滕滕被の浸潤性進展における炎症性サイトカイン IL-1 の役割

岡田鿆一, 沢井博純, 时中守伺, 真辺忠夫

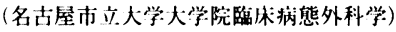

[はじめに] 今回我々は，代表的炎症性サイトカインである IL-1 か腾㿋細胞の浸 洞能を六進させる一つつの機序として, MMP(matrixmetalloproteinases)に注目し, 興味深い結果を得たので考察を加え報告する。

[対象と方法] 滕需細胞 MIA PaCa-2に IL-1 作用させ, MMP-9, MT1-MMP の発現，及び活性の変化を Western Blot，Zymographyにて検討を行い，結果を Densitometryにより定量化した.

[桔果] MIA PaCa-2にIL-1を作用させたところ，MMP-9, MT1-MMP の発現の 有為な增加を認めた（IL-1 1.0ng $/ \mathrm{ml}: 4.3$ fold, $10 \mathrm{ng} / \mathrm{ml}: 7.4$ fold). Zymography では IL-1により MMP-9の活性が有為に上䄯しているのが示された (IL-1 1.0ng/ $\mathrm{ml}: 4.1$ fold, $10 \mathrm{ng} / \mathrm{ml}: 4.8$ fold $)$.

[考察] 炎症性サイトカイン IL-1が有為にMMP-9の発現，活性を六進させてお ク，IL-1はこの機序を介して羘都の浸润を促進させている叮能性が示唆された。

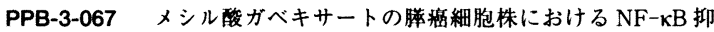
制効果についての検討

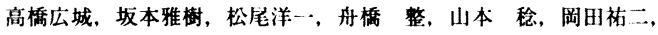

早川哲史, 田中守腩, 竹川廣光, 真辺忠夫

(名古屋市立大学大学院臨床病態外科学)

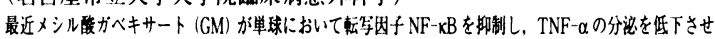

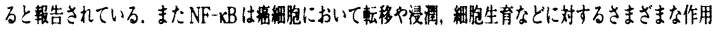

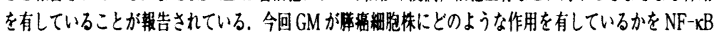

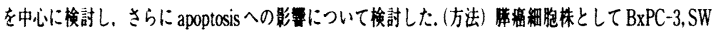

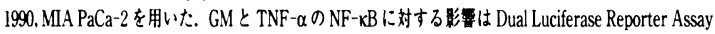

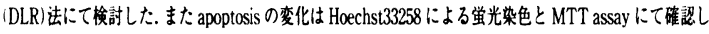

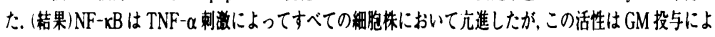

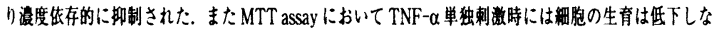

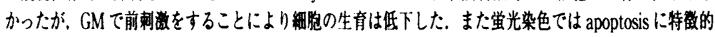

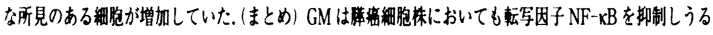

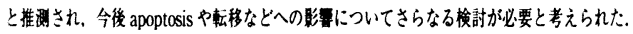

PPB-3-068 膡癌の新しい腫堭マーカーの開発-抗血管新生性アンチ トロンビン III 抗体の臨休纫用-

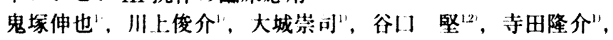

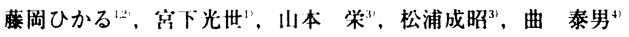

(国立病院長崎医療七ンター外科"，国立病院長崎医旗七ンター臨床研究 センター2. 大阪大学大学院保険学科機能診断科学講座 ${ }^{3}$, キューメイ研 究所")

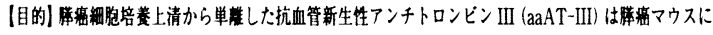

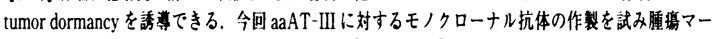

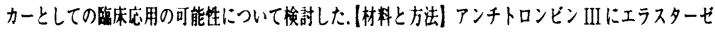

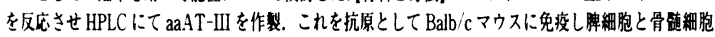

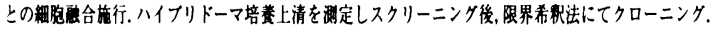

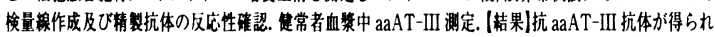

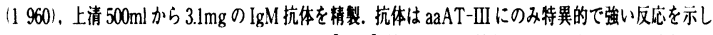

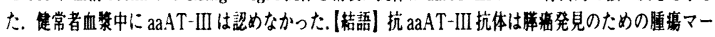

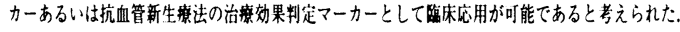

PPB-3-069 ゲムシタビン暴露による膡癌細胞株の分子生物学的検討 年光宏明 ${ }^{1.2}$, 山本光太郎", 河岡 徹", 飯塚德男", 橋本毅一郎 ${ }^{12}$, 丹黒 章", 佐々木功典", 岡 正朗"

(山口大学第 2 外科", 山只学第 2 病理"')

【はじめに】ゲムシタビン投与により膡瘦患者の延命効果や，QOL 改善の報告がさ れている.ゲムシタビン作用のより詳細な解明のため胼癌細胞株（YPK-1）を用い て異なる浱度暴露での, 経時的な分子生物学的変化を検討した.【方法・結果】 YPK

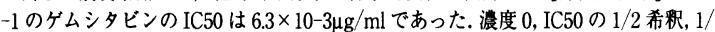
4 希积での YPK-1 細胞增殖は涱度依存性に抑制された．各系の $1,6,12,24$, 及び 72 時間培養後に細胞周期を測定した. $1 / 2$ 希釉では早期より early $S$ 期において增殖停 止しているが, $1 / 4$ 希釈では late $S$ 期にて蓄積していた細胞が 72 時間後には re-entry していた. cDNA microarrayを用いた遺伝子発現変化では浱度 0 と比較して 1 / $2,1 / 4$ 希粕に暴露した場合各䄪 120 の遭伝子の発現変化を認めた。道伝子発現の経 時的変化を SOMにて解析した. クラスター分類にて各遺伝子群が経時的にどのよ うな発現変化をしているかを認識し得た. [結語】ゲムシタビン浔度の違いによりど のように紐胞增殖抑制が起こっているかを経時的遺伝子の発現変化にて検討した.

PPB-3-070ＢNIP3 は膦癌において塩酸 Gemcitabine 感受性に影響を 及はす

赤田昌紀, 砂村覓琴, 江川新一, 乙供 茂, 武田和憲, 松野正紀 (東北大学大学院消化器外科学)

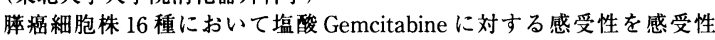
群, 预性群, 中間群に分類し, 細胞株の遣伝子発現を cDNA マイクロア レイを用いて解析した。ここの結果感受性群と耐性群間で異なった発現を 示す遺伝子 8 種を同定することができた.この中でアポトーシス関連遺 伝子の Adenovirus E1B-19K/BCL-2 interacting protein（BNIP3）遺伝 子に着目し, RNA interference(RNA 干涉法)を用いて塩酸 Gemcitabine 感受性細胞株 CfpaclにおけるBNIP3の発現を抑制したところ，塩酸 Gemcitabine に対する感受性は有意に阻害された. 切除羘癌組織 23 検体 における BNIP3 の発現を qPCR 法で調べたところ 13 例にて発現低下， 3 例で高発現を認めた. BNIP3 は滕癌の薬剤酎性機構において重要な因 子であり, 今後より効果的な腪癌化学療法の開発とテーラーメイド治療 への応用が期待される.

PPB-3-071 羘癌の間質增生を引き起す浸潤性顆粒球由来の TGF- $\beta$

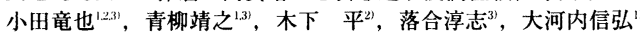

(筑波大学消化器外科", 国立がんセンター東病院肝胆滕外科 ${ }^{21}$, 国立がん センター研究所支所・臨床腫瘍病理部 ${ }^{3}$ )

羘撚は激しい間質增生を特徽とするが，この分子機構を解明する為にコラーゲンと間質唀導の 可能性がある增殖因子 (TGF- $\beta$, CTGF, acidic FGF, basic FGF, PDGF A, PDGF C, EGF)

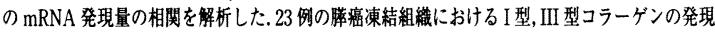

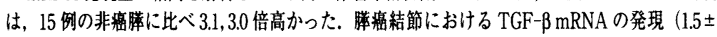

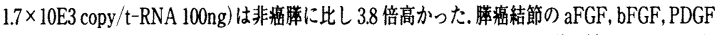
Cの mRNA 発現は 3.7, 2.6, 2.8 倍高かったが, CTGF, PDGF A, EGFは逆に低かった。 これら の增殖因子のうち、コラーゲン mRNA 発現と最も高い相関を示したのは TGF- $\beta$ であった。過 剩発現した TGF- $\beta$ の由来を同定する為に腾藉組織を免疫染色した所, 羘がん細胞は非常に淡い 染まりを示すに留まったのに対し，主に浸洞先端部のがん胞坚周囲に存在する遊噰緗胞が強い

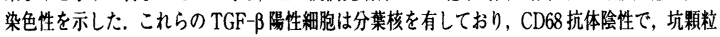

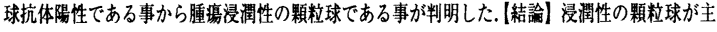
にTGF- $\beta$ の供給源となり，滕癌の間質增生をもたらしている可能性が高いと考えられた。

PPB-3-072 芽癌における PEDF 発現と腫瘍内新生血管密度の検討 上原浩文, 宮本正樹, 長谷龍之介, 海老原裕磨, 金古裕之, 橋本裕之, 村上慶洋, 奥芝俊一, 近藤 哲, 加藤紘之 (北海道大学大学院腫瑒外科)

(はしめに腾癌においては，腫場内新生血管密度と肝転移との間に正の相関が見られること が報告されている. Pigment epithelium-derived factor (PEDF) は網膜色素上皮緗胞において 発現が確認された遭伝子産物であり，強力な血管新生阴害物質であることが知られている。

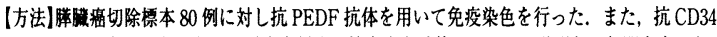
抗体を用いた免疫染色を行い，腫㣀内新生血管密度を計算し，PEDF 発現との相関を求めた。 【結果】 PEDFに求いては高発現群 22 例, 低発現样 58 例であった. PEDFの発現と新生血管 密度の間には負の相関を認めた $(\mathrm{P}=0.0003 ; \mathrm{Mann}$-Whitney U test $)$. 肝転移と PEDF 発現の

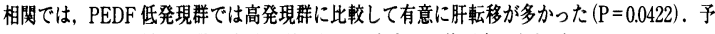
後との相関では，低発現群は高発現群に比べて有意に予後不良であり $(\mathrm{P}=0.0026 ;$ logrank test）(3 年生存率 $13.8 \%$ vs $40.9 \%$ )，Cox の比例ハザードモデルにおけるる多変量解析では独立予

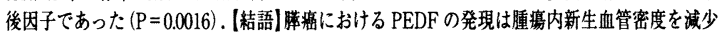
させ、肝転移の類度を溥らすことにより，予後を改善していると考えられる。 
PPB-3-073 MT-21 inhibits cell growth and invasiveness through AP-1 in pancreatic cancer cells

坂本雅樹, 山本 稳, 高橋広城, 松尾洋一, 沢井博純, 舟橋 整,

岡田祐二, 竹山廣光, 真辺忠夫

(名古屋市立大学大学院臨床病態外科学)

[目的] 滕瘦の予後を改善するためには滕癌の浸潤転移を制御する必要があり，本研究で は, ヒト白血病細胞にアポトーシスを誘導する MT-21の勝癌細胞に対する効果を検証し た. [方法] ヒト滕癌細胞株 4 種（高肝転移株 BxPC-3,SW 1990 および低肝転移株 Capan -2, MIA PaCa-2) を用い実験を行った. [結果・考察] (1) MTT assay, Invasion assay

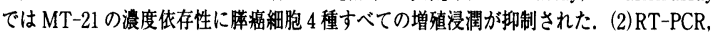
Western blotting では, 羘癌細胞 4 種すべてで c-jun mRNA および蛋白の発現を確認し， 細胞株間で発現に大きな差は認めなかった. (3) EMSA では, 定常状態での膁癌紐胞高肝 転移株では低肝転移株に比べ NF- $\mathrm{kB}$ 活性は高く， AP-1 活性は低かったので, NF- $\mathrm{kB}$ が肝転移を促進し, AP-1が抑制するという可能性が示唆された.また MT-21 投与により 洤度依存性に AP-1 活性が増加した. 以上より, MT-21 は AP-1 を介して勝䍃細胞の增殖 浸潤を抑制すると考えられ，MT-21を用いた羘癌治療への新しい可能性が示された。

PPB-3-074 茦癌細胞でのPPAR $\gamma$ リガンド誘導アポトーシスにおけ る MAPK の役割

橋本幸直 ${ }^{1}$ ， 仁尾義則"，小池 誠"，板倉正幸 ${ }^{1}$ ，矢野誠司 ${ }^{1}$,

桶上哲哉 ", Evers B. Mark ${ }^{2)}$

(島根大学第 1 外科", The University of Texas Medical Branch ${ }^{2}$ )

【目的】PPAR $\gamma$ リガンドは抗腫瘍効果を示すことが知られており，MAPK シグナルは癌細胞のアポトーシス誘導において重要な働きを担っている. $15 \mathrm{~d}-\mathrm{PGJ}_{2}$ の㬸癌細胞アポトーシス誘遒における MAPK シグナルの役割 について検討した.【方法】 MIAPaCa-2 を用いて $15 \mathrm{~d}-\mathrm{PGJ}_{2}$ の MAPK 活性 化効果，および各 MAPK (p38,JNK，ERK) シグナル経路の抑制によるア ポトーシス誘導変化を解析.【結果】15d-PGJ を活性化した. p38 経路の抑制で $15 \mathrm{~d}-\mathrm{PGJ}$ 誘導アポトーシスが有意に滅少 した.この効果は JNK 経路の抑制にてさらに増強された．逆に，ERK 経路の抑制ではアポトーシス誘導が有意に増強した.【結語】15d-PGJ $\mathrm{J}_{2}$ 誘遒 アポトーシスにおける MAPK シダナルの関与が示され, ERK 経路の抑制 は $15 \mathrm{~d}-\mathrm{PGJ}_{2}$ の抗腫瘍効果をさらに高める可能性が示唆された.

PPB-3-075 腪癌切除症例における末梢血樹状細胞の予後予知因子と しての有用性

柳本泰明, 高井惣一郎, 里井壯平, 豊川秀吉, 高橋完治, 寺川直良,

權 雅憲, 上山泰男

(関西医科大学外科)

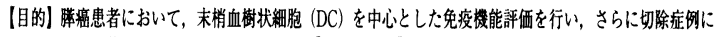

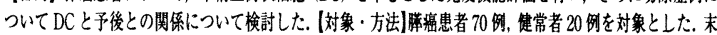
梢血中のリンパ球分画, DC1 (myeloid DC) /DC2 (lymphoid DC) 数をフローサイトメトリーで解析した.

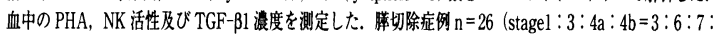

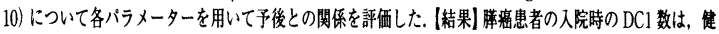
常者と比較して有意に低值であった. PBMC 数, DC 総数, T 紐胞数, NK 緗胞数, PHA 及び NK 活性には 両群間に差は無かった，切除症例の DCl 数仗非切除症例の DCl 数に比べ有意に高值であった。屏切除症例 に関して, stage $4 \mathrm{a} / 4 \mathrm{~b}$ 群 $(\mathrm{n}=17)$ の DCl 数は stage $1 / 2 / 3$ 新 $(\mathrm{n}=9)$ の DCl 数に比べ有意に低值であっ た. $\mathrm{DCl}$ 数高值群 $(\mathrm{DCl} \geqq 5000 \mathrm{cell} / \mathrm{ml})$ は $\mathrm{DCl}$ 数低值群 $(\mathrm{DCl}<5000 \mathrm{cell} / \mathrm{ml})$ に比べ有意に予後良好であっ た. 両群間に年龄, 性差及びR (residual tumor) に差は無かった，その他のバラメーターと予後との相関 は認められなかった.[結語] 腾癌患者の入院時 DCl 数は予後予測因子となる可能性が示唆された。

PPB-3-076 肝再生による肝内移植腪島の生着促進効果一勝切除後自 家腪島移植の成績向上にむけて一

首藤 毅 ${ }^{1}$, 槍山英三 ${ }^{2}$, 横山雄二郎 ${ }^{1}$, 村上義昭 ${ }^{1}$, 末田泰二郎 ${ }^{1}$

(広島大学第 1 外科 ${ }^{1}$, 広島大学総合診療部 ${ }^{21}$ )

【目的】慢性䐙炎に対する外科治療は，本邦では羘管ドレナージを中心とした術式が巽択されて いるが, 欧米では勝全摘後に腾島を肝内に自家移植する術式も選択されている。勝切除後自家膡 島移植の成績向上にむけて, 移植の場である肝の再生能力を利用して移植䐙島の生着率を向上 できることをラット膵島移植モデルにて検証する. [対象と方法]近交系 F344 ラットを滕島移植 のドナー及びレシピエントに使用した. Streptozotocinにより糖层病ラットを作製し，ドナーか ら单離した䐙島を $70 \%$ 部分肝切除群 (HxPIT $; n=12)$ と非肝切除群 (PIT ; n=10) に経門腺 的に肝内へ移植した. 勝島移植後の機能評価は随時血糖と体重增加率の推移, 糖負荷試験, 血中 インスリン港度(ELISA), 生着は免疫組織学的に評価した.[結果]随時血楉は HxPIT 群で有意 な低下が移植後 4 週間持続し, 体重增加率は HxPIT 群が高かった. 糖負荷試験は HxPIT 群で 酎楉能の改善を認め, 血中インスリン䟴度も HxPIT 群が高かった. 肝の免疫組織学的評価では 移植後早期から HxPIT 群で良好な機能的生着を認めた. [結論]部分肝切除後の再生肝に满島を 移植することにより機能的生着（移植滕島のインスリン分泌）の促進効果を認めた。
PPB-3-077 辇瘦細胞株 A818-1 に対する NF- $K B$ 阻害剂併用 TNF 療 法の apoptosis 誘導効果

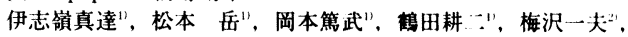

万井雅和

(東京都立駒込病院外科", 慶應大学理工.学部")

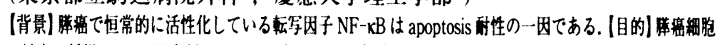

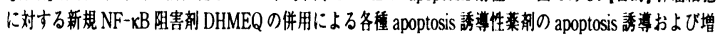

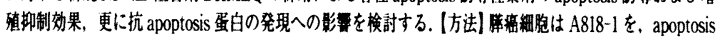

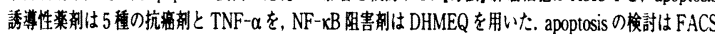

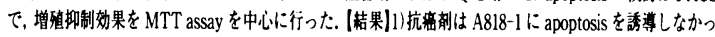

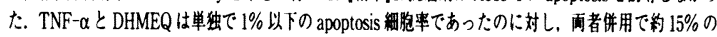
apoptosis 絧胞が出現した. 2) apoptosis 細胞は 6h 前後をどークに出現した.3) 併用により相乗的な増殖

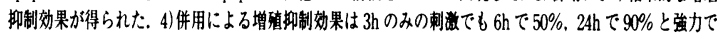

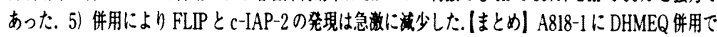

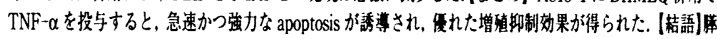

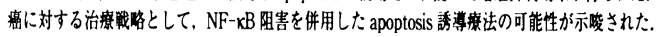

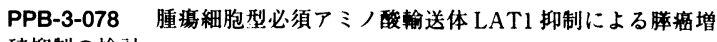
殖抑制の検嘼

松本伸明"，阿部展次"，正木忠彦"，森 俊幸"，杉山政則”。

金井好克 ${ }^{2 !}$, 遠藤 $1^{2}$ ", 跡見 裕"

(杏林大学第 1 外科", 杏林大学楽理学 ${ }^{21}$ )

(目的) 我々が分子実体を明らかにした必須アミノ酸の送体 L-type amino acid transporterl

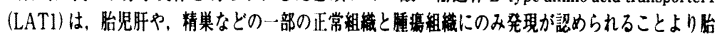

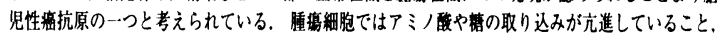

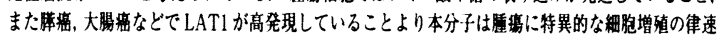

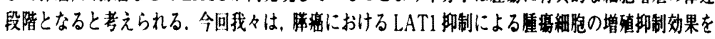

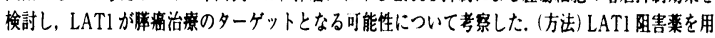

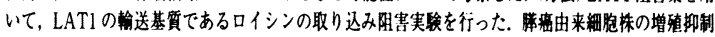

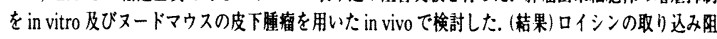

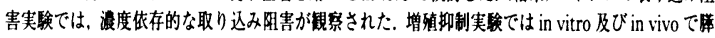

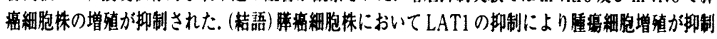

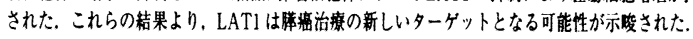

PPB-3-079 LIF (Leukemia inhibitory factor) の cyclin Eを介した䐙 瘦細胞の增殖促進作用について

蒲原英伸"，高橋将史"，石河隆敏"，箕田誠-1", 酒本喜與志",

江上 宽", 小川道雄 ${ }^{21}$

(熊本大学第 2 外科", 宮崎県市延岡病院外科"

【目的】 LIF (Leukemia inhibitory factor) は自血病緗胞およびマクロファージの分化制 御の他に種々の生物活性を有している炎症性サイトカインである。本研究では、样總細胞

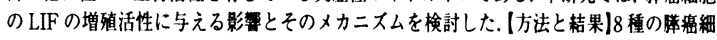
胞は, LIF mRNA (RT-PCR)および蛋白を発現し(ELISA)，同時にレセプター(LIFRbeta, gp130) mRNA を発現していた (RT-PCR). Hs700TにおいてLIF mRNA の発現は TNF -alpha, IL1-beta 刺激により增強した. LIF 刺激によっても䈨度依存性にLIF mRNA の発現增強を認め,この発現に junB mRNAの発現が関与していた(Northern blotting). また, Hs700T は LIF 刺激により浱度依存性に細胞周期に関する cyclinEの発現が立進し (Northern blotting)，細胞増殖は有意に促進し, LIFR-beta antisense の投与により有意に 抑制された (MTT)。【考察】䐙䌁病態において，LIF およびそのレセブターの発現を制御 することは，炎症による病態の悪化を防ぎ需の増殖を抑制する叮能性が示唆される.

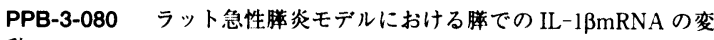
動 林 次郎, 浦上, 淳, 角田 司 (川崎医科大学消化器外科)

[目的] ラット重症急性膵炎モデルを作成し, IL-1 及びTNF 合成阻害 剂 (FR167653)の投与による血清中の IL-1 $\beta$ との変化と䐙熯での mRNA の発現を検討した［方法］1） sham 群 2) 滕炎群：十二指腸内にポリ塩 化ビニルチューブを結禁固定し作成 3）FR 群：膡炎群作成後より FR 167653 を $1.5 \mathrm{mg} / \mathrm{kg}$ を生理食塩水 $0.2 \mathrm{ml}$ に溶解させ毎 15 分ごとに 4 回

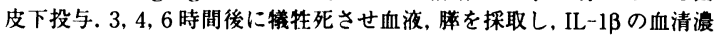
度と勝腈での IL-1 $\beta$ の mRNAの発現を検討した. [結果] 1) 血清 IL-1 $\beta$ は勝炎群では上昇を認めた．FR 群では上昇が抑制された，2）勝滕で

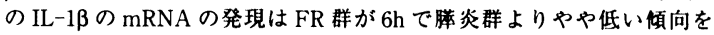
認めた. [結語]FR167653の投与により血中 IL-1及の産生が抑制された. 膵での IL-1 $\beta$ の mRA は, 抑制される傾向にあった. 


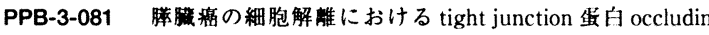
と MEK/ERK シグナル伀達径路の関与

譚 暁冬、江上寞，石川晋之，中川真英，古賀宙勝，廣田脂彦 (熊本大学第 2 外科)

【目的】滕緮の細胞解離の機構を明らかにするH的で, tight junction 蛋白 occludin とシタナル伝達物質 MEK 及びERKの発現を免疫細胞染色により検討した. 【方 法と成績了島状に增殖する PC-1 とヒ卜滕絊緗胞株 CAPAN-2 細胞において, 弱 いMEK :ERK 発現とoccludin の細胞膜における強発現を認めた。これに対して,

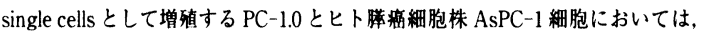
$\mathrm{MEK} / \mathrm{ERK}$ 强発現を認めたが紐胞膜には occludin 発現を認めなかった。 PC-1 とCAPAN-2 細胞に細胞解離因子を添加すると，細胞は解離し，細胞膜における occludin の発現が娍弱し，同時にMEK/ERK 発現が誘道された. MEK 抑制剂の U0126で PC-1.0 と AsPC-1 細胞を处理すると, MEK/ERK 発現が抑制され，同時 に，紐胞膜に強く occludin が発現し，細胞接着が誘導された.【結語】Occludin の細胞内局在と MEK/ERK シタナル伝達怿路が細胞解離に强く関連し, tight junction 蛋白の局在変化により滕藉細胞の細胞解離が誘導されると考えられた。

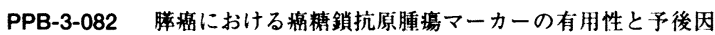
子としての役割

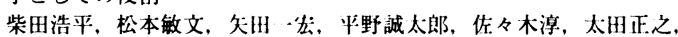
北野正㓮

(大分大学第 1 外科)

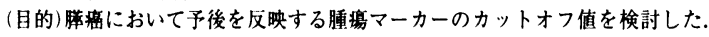
(対象と方法) 対象は外科切除した滕疾患 93 例で, CA19-9, DUPAN-2, SPAN -1の 1) 相関関保 2) ROC 曲線とカットオフの設定 3）滕浸潤癌の予後を検討 した. (䊅果) 1) CA19-9 と SPAN-1 $(r=0.854)$, DUPAN-2 と SPAN-1 $(r=$ 0.323) が相関した. 2) ROC 曲線下面皘は CA19-9:0.782,SPAN-1 :0.858, DU PAN-2 : 0.774 で SPAN-1 が優れており, 特異度 0.95 (CA19-9: 194IU, SPAN $-1: 83$ IU, DUPAN-2 $: 405 I U)$ をカットオフとした，3） 5 年生存率と検定結果 (\%,p-value) は, CA19-9 (陰性 $30 \%$, 陽性 $5.1 \%, p=0.0026)$ ，SPAN-1（陰 性 $36 \%$ ，陽性 $5.0 \%, \mathrm{p}=0.0068$ )，DUPAN-2(陰性 $29 \%$ ，陽性 $8.9 \%, \mathrm{p}=0.23$ ) であった（䊅語）癌のスクリーニングはSPAN-1が最も有用であり，CA19-9 と SPAN-1は瘦診断の特異性が 0.95 のカットオフで予後を反映した.

PPB-3-083 䐙全体にびまん性に多発した滕内分泌腫堭の一例

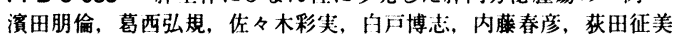
(国立札㹸病院・北海道がんセンター外科)

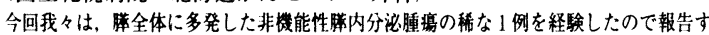

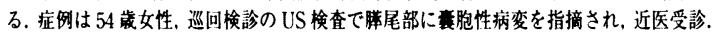

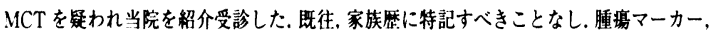

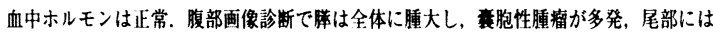

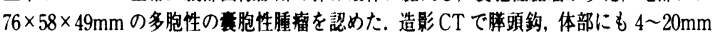
の hypervasucular tumor が多発，充実性病変の存存も筷われた：下垂体，副甲状腺に腫

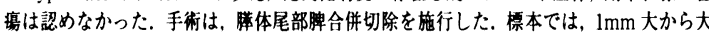

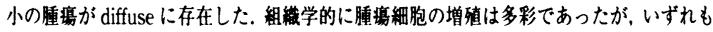
均一で異型は強くなく mitosis も目立たず, ki67の index は $3 \%$ 以下であった。免疫染色

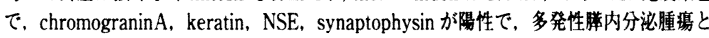
診断した，尾部の腫晹徉か大きく，悪性を完全には否定できないと診断した，残存滕の追

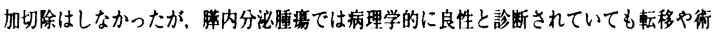
後再発する例も報告されており，今後注意深い経過稓察が必要と思われる。

PPB-3-084 急速に增大し，主膡管の限局性狭窄を伴った滕漿液性表 胞腺腫の 1 例

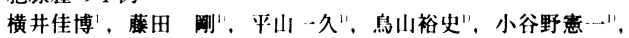

白沢春之 ${ }^{2}$

(社会保険浜松病院外科", 社会保険浜松病院病理科 ${ }^{2}$ )

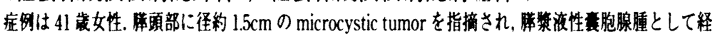

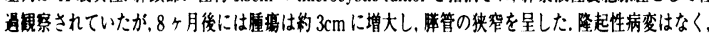

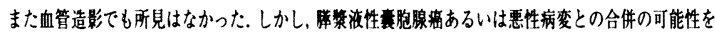

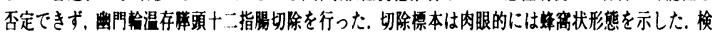

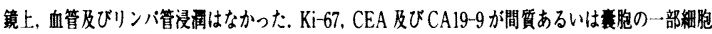

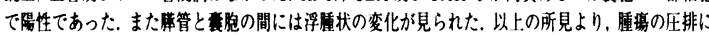

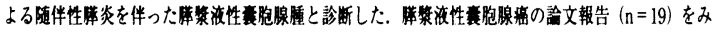

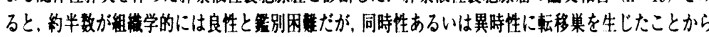

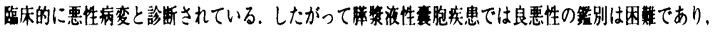

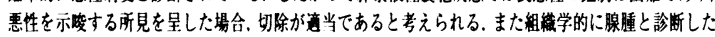

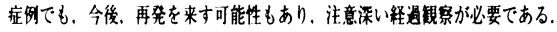

PPB-3-085 血管合併切除が必要であった羘 Solid-pseudopapillary tumor の一例

出口智宙, 杉本博行, 井上総一郎, 竹田 伸, 金子哲也, 中尾昭公 (名古屋大学第 2 外科)

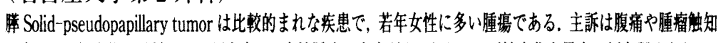

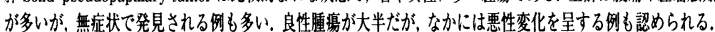

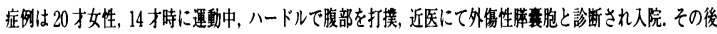

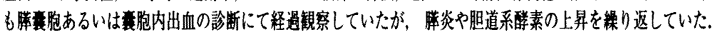

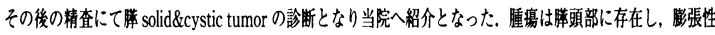

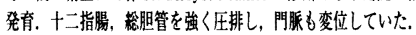

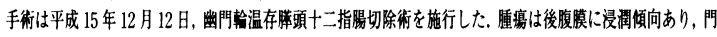

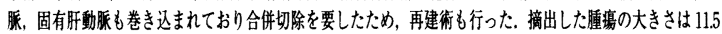
$\mathrm{cm} 8.5 \mathrm{~cm}$ であった.

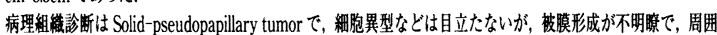

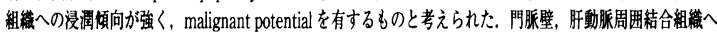

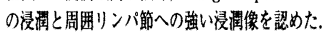

PPB-3-086 経過観察中に腫瘍径の増大を来たし手術施行した滕漿液 性辜胞腺腫の 1 例

田崎健太郎, 大島郁也, 有我隆光, 吉村清二, 左古知久, 篠篻浩一, 岡崎靖史, 早野康一, 成本壮一, 尾崎正彦

(横浜労災病院外科)

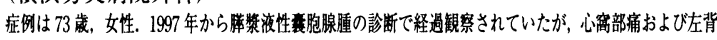
部痛を主訴に，2003年5月精査加都目的に紹介受診. USの経墖は, 9 年前は $10 \mathrm{~mm}, 8$ 年前は $32 \mathrm{~mm}, 6$

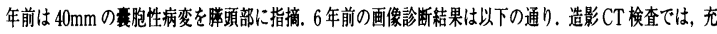

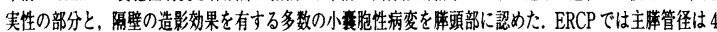

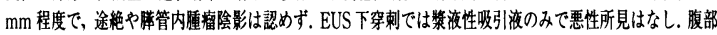

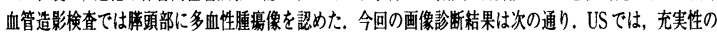

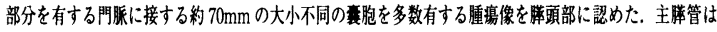

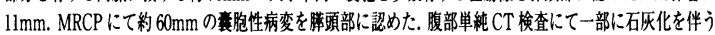

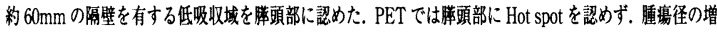

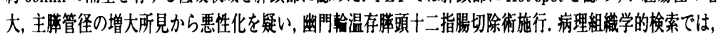

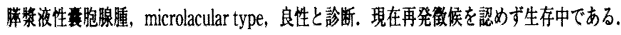

PPB-3-087 男性滕 Solid pseudopapillary tumor $の 3$ 例 林 直輝, 大東誠司, 嶋田 元, 榾瀨信太郎, 西尾剛毅 (聖路加国際病院外科)

はじめに：腆 Solid pseudopapillary tumor（SPT）は若年女性に多いとさ れ, 男性例は比較的稀とされている.男性における滕 SPT の 3 例を経験 したため報告する. 症例 $1: 11$ 歳男児. 外傷を契機に上腹部痛が出現した ため受診. 左季肋部および下腹部に圧痡を認めた. CT, MRIで大きさ 6 $\mathrm{x} 5 \mathrm{~cm}$ の腫堭内出血を伴う境界明暸な腫瘤を認めた。症例 $2: 35$ 歳男性. 肺結核治療中にたまたま施行した胸部 CT にて膆腫瘍を指摘. CT, MRI で $6.5 \times 5.5 \mathrm{~cm}$ のSPT が疑われた. 症例 $3: 34$ 嵗男性. 腹部エコーにて苏 腫場を指摘. CT で $5.5 \mathrm{~cm}$ の SPT が疑われた. 全例膵体尾部切除が施行さ れ, SPT の病理診断を得た. 自検例 3 例とも経過は良好である. 考察：膵 SPT は若年女性に多いが, 近年では男性の報告例も散見されるようにな り，本邦における男性 SPT は自験例を含め 49 例の報告がある。年龄は 12〜75 歳 (平均 33.4 歳) であった. SPT の約 15\% は男性として報告され ており, 男性例は決して稀ではない. 自験例 3 例とも経過良好である.

PPB-3-088 退形成性捇管癌（紡鍾細胞型）の一例

高曾寬年, 佐々木明, 佐々木薰

(佐々 木外科病院外科)

症例は 78 歳女性. 平成 15 年 9 月 10 日吐血で受診し出血性胃潰場と診断. 内視鏡的 に止血できず開腹し胃切開糔合止血術にて止血. 術後から食欲不振, 背部痛が出現. 腹部エコー, 腹部 CT 検查で, 滕体尾部に $10 \times 9 \times 6.3 \mathrm{~cm}$ の境界明瞭な多房性の Cystic tumor を認めた. CEA $0.8 \mathrm{ng} / \mathrm{ml}$ と正常だった. 腹部 MRI, 腹部血管造影を行

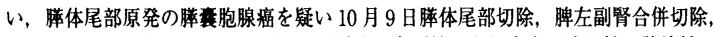
胃部分切除術を行った。切除標本では，腫場は多房性であり内容は淡血性の漿液性で あり，胃壁に $4 \times 3 \mathrm{~cm}$ の簿囲で浸潤していたが出血した胃溃湟とは別部位であった. 病理組織所見で退形成性膵管癌の紡錘細胞型と診断. 術後は症状が改善され 11 月 30 日退院した. 平成 16 年 1 月腹部 CTにて局所再発と多発肝転移を認めた。考察.

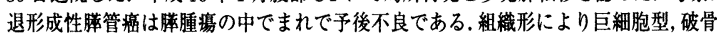
細胞型，紡鍾細胞型と三種類に分類される.この中でも本症例である紡錘細胞型は最 も頻度が低く極めてまれである。退形成性羘管癌自体比較的まれな症例であるが,さ らに頻度の低い紡鍾細胞型を経験したので若干の文献的考察を加えて報告した。 
PPB-3-089 右下腹部痛にて発症した辇頭部血管腫の1例 池上克徳, 村上敬一, 河村祐一郎, 本郷弘昭 (山鹿市立病院外科)

右下腹部痛にて発症した極めて稀な䐙頭部血管腫の 1 例を経験したので報告する。 症例は, 53 藏男性. 持続する右下腹部痛を主訴に当科紹介された. CTにて勝頭部 から羘鈎部にかけて造影早期に著明に enchance される腫㿔と門脈シャントの所見 を認めた.MR アンギオにて約 $5 \mathrm{~cm}$ 大の腫瘤として描出された.腹部血管造影では, 胃十二指腸動脈と下䐙十二指腸動脈より栄養される血流豊富な腫㾿として描出さ れた. 胃内視鏡にて十二指腸 2nd portionに出血を認め, 貧血の原因は粗頭部の病変 由来のものと推察された. 右下腹部痛の原因も上腸間膜動腺の血流が䐙頭部の病変 により steal されることによる abdominal angina と診断した. 2003 年 12 月 11 日手 術施行. 羘頭部から羘鈎部かけて拡張した血管からなる胡桃大の柔らかな腫㿑を認 め, PpPD を施行した. 摘出した標本では勝頭部から鈎部にかけて存在する $4 \times 4 \mathrm{~cm}$ 大, 乳白色調, 弾性軟の腫嘴であった. 病理組織検査では腫瑝部は大小の内䏶を有 する静脈より構成され，一部は著明に拡張した内㓐を有し, mixed venous and cavernous hemangioma と診断された. 手術後は貧血の増悪, 腹痛とも消失した.

\section{PPB-3-090 䐙内副脾原発リンパ管腫の一例}

岸本圭永子"，八代正和"，山田靖哉"，山下好人 "，仲田文造"，

大平雅一" , 西口幸雄 ${ }^{2}$, 加藤保之 ${ }^{3}$, 西野裕二"1, 平川弘聖

(大阪市立大学腫湯外科", 大阪市立総合医療センター消化器外科 ${ }^{21}$, 大阪 医療刑務所 ${ }^{3)}$ )

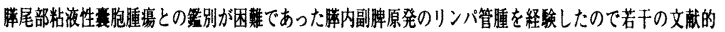
考察を加え報告する.症例は 57 歳男性. 平成 14 年 11 月の検診でCA19-9值上昇を指摘され当院内科受

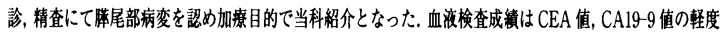
上具を認める以外異常所見はなかった。腹部超音波検查で羘尾部に $23.5 \times 19.5 \mathrm{~mm}$ の寒胞性病変を認め

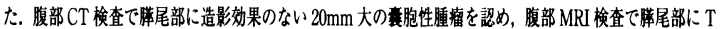

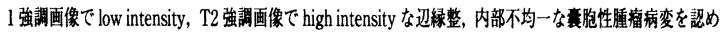

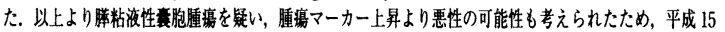

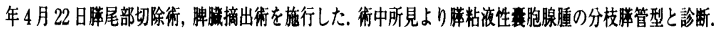

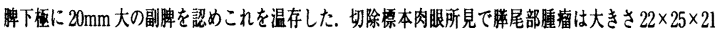

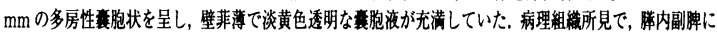
発生したリンバ管腫（Cavernous type）と診断された，術後9ケ月経た現在，経過良好である.

PPB-3-091荤全摘を施行した腪内二重㿋の一例

江菩秀和, 桑原道郎, 西躰隆太, 恒川昭二, 滝 吉郎 (関西電力病院外科)

症例は 69 歳女性. 63 歳より糖尿病にて外来通院治療中. 平成 15 年 1 月に 4 ヶ月で 5 $\mathrm{kg}$ の体重減少に気付いた. 3 月 7 日血液検査で肝胆道系䤃素の上型あり, 腹部超音波検 查で総胆管と主脇管の拡張，羘頭部に直径 $2 \mathrm{~cm}$ の low echoic mass を指摘されたため, 3 月 11 日精查目的に入院. 腹部 CT, MRI 検査では勝頭部の病変は描出されなかった が, 体部に造影効果の少ない $3 \times 2 \mathrm{~cm}$ の mass を認めた. ERCP 検査で主羘管は頭部か ら尾部まで拡張しており，頭部，体部にはそれぞれ約 $1 \mathrm{~cm}$ の狭窄を認めた．総胆管も 直径約 $2 \mathrm{~cm}$ と拡張していた，血管造影検査では，横行缕動脈の起始部に台形状の迁回 と壁不整および狭小化を認めた。 以上の所見より，羘頭部の腫瘍は診断が困難であった が体部の腫瘍は䐙癌と診断し, 4 月 4 日開腹手術を施行した. 羘体部の硬結と同部への 膡被膜の巻き込みを認めたが周囲への浸潤は認めず，これを incisional biopsyしたと ころ ductal cell carcinoma と診断された. 頭部の腫瘍も癌が否定できず, 䐙全摘, 脾合 併切除術を施行した．最終病理組織診断は滕頭部および体部の腫湯両者ともductal cell carcinoma であり，総胆管狭窄は頭部の腫場によるものであった.

\section{PPB-3-092 膵芽腫の 2 例}

森村絵里"，花房徹兒"，上村 良"，山本道宏" ${ }^{2}$, 横井暁子 ${ }^{3}$

(大津赤十字病院小児外科 ${ }^{12}$, 洛和会音羽病院外科 ${ }^{21}$, 大阪赤十字病院外科 ${ }^{31}$ ) 滕芽腫の 2 例を経験したので報告する. (症例 1]2 歳女児. 主訴 : 左腹部腫嘴. 血清 AFP： $1612 \mathrm{ng} / \mathrm{ml}$. 後腹膜に $12 \mathrm{~cm}$ 大の石灰化を有する腫第を認め, 奇形腫と訩断, 開腹術施行. 膡尾部に付着する腫瘤と多数のリンパ節転移を認め, 羘尾部を含む腫瘾摘出術を施行. 病 理所見にて腾芽種と診断. 術後血清 AFP 值は正常化したが 4 ケ月後に再上昇, 以後局所 再発を来たし, 2 度の開腹手術と VBP・VAC 療法を施行するも術後 2 年で死亡. [症例 2] 16 歲男児. 主訴：全身倦总感，体重減少．血清 AFP：3092ng $/ \mathrm{ml}$. 苇頭部に $6 \mathrm{~cm}$ 大の腫

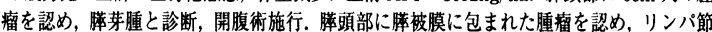

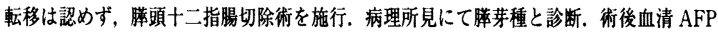
值は正常化，2 年後の現在再発の兆候は認めない.【とめ】 羘茅腫は，現在までに 100 数例の報告を認めるのみで, 10 歳までの小児例が多く 16 歳以上の思春期・成人例は 10 数例と少ない. 小児例では血清 AFP 值が診断に有用であり，再発の指標にもなる。治廉 は外科的切除が原則である. 転移なく腫竲全摘が可能な症例は予後良好であるが, 切除不 能例は予後不良であり, 術前化学療法や術後放射線療法の適応となる。
PPB-3-093 原発巣切除後補助撩法により舆期生存を得ている多発肝 転移を伴うソマトスタチノーマの 1 例

北村好史, 横尾淔樹, 木元道雄, 白子隆志, 洁组隆浩, 田中善宏,

濱洲晋哉, 長田博光, 塩田哲也, 阙本清尚

(高山赤十字病院外科)

今回我々は，多発肝転移を伴うソマトスタチノーマに奶し，原発巣切除術後肝動腃塞栓術を路り返

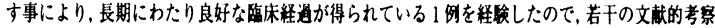
を加えて報告する. 症例は 40 歳，女性. 平成 10 年 9 月，全身倦急感と体重少で当院を受診した。

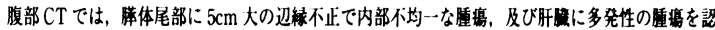

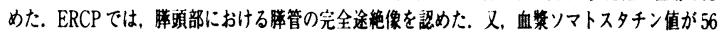

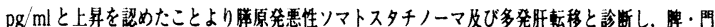

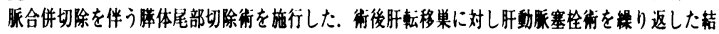

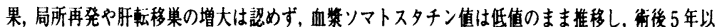

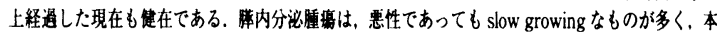

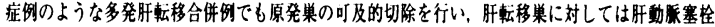
術等の補助的治痖を行うことによって，QOLを保ちながら長期生存が得られたため報告した。

\section{PPB-3-094 䐙原発小細胞軸の 1 例}

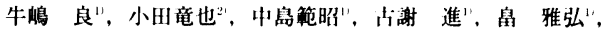

石川 誠", 大河内信弘"

(水府病院外科"), 筑波大学消化器外科" ${ }^{2}$ )

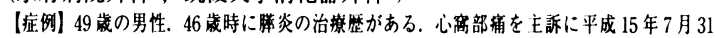
日に当院紹介人院. 血清アミラーゼ716IU/1 と高值を示し腹部 CTで勝頙部内に限局する低吸

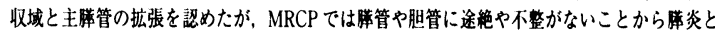
して治療を行った．しかしその後の腹部 CTで低吸仪域は急速に增大し周囲のリンパ節腫脤

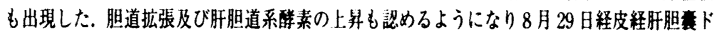

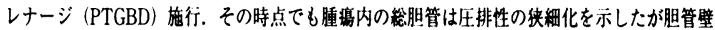
に不整はなく，MRCPでも䐙管の途䋓や不整は認めなかった，9月30日，診断確定のため経

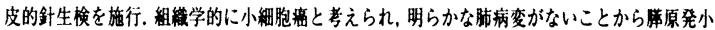

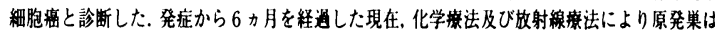

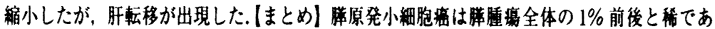

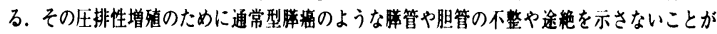

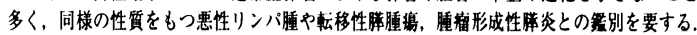

PPB-3-095 von Hippel-Lindau 病に合併した腎細胞癌, 羘頭部腫廈の 1 切除例

大沢晃弘"，炭山嘉伸"，䊉原宏久"，渡造 学"，田中英則"，

浅井浩司 ${ }^{\prime \prime}$, 榎本俊行"，松清 大"，金井亮太"，大原関利章

(東邦大学第 3 外科", 東邦大学大橋病院病理部 ${ }^{21}$ )

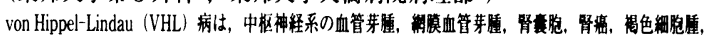

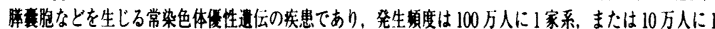

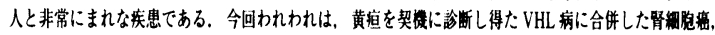

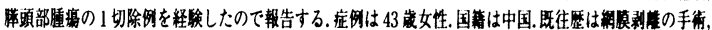

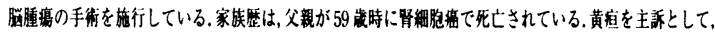

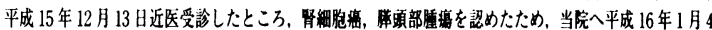

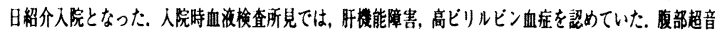

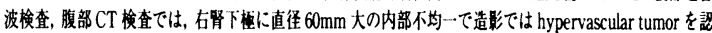

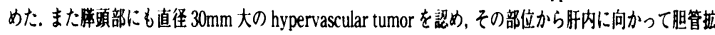

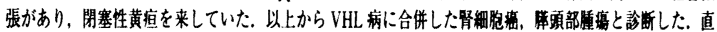

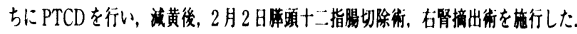

\section{PPB-3-096 羘分節切除術を施行した小览膁来腫の1例}

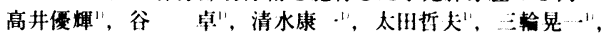
小泉昌-2!, 宮本正俊 ${ }^{3 !}$

(金沢大学大学院がん局所制御学 ${ }^{11}$,金沢大学大学院医学研究科小児科 ${ }^{2}$, 富山市民病院小少外科 ${ }^{3 \prime}$ )

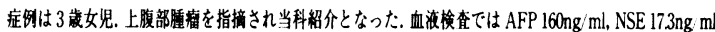

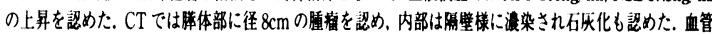
造影では充実性部分に血管增生が見られ，壁を中心に港染像を示した，以上より库芽盾を考え，平成 15

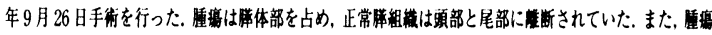

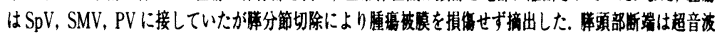

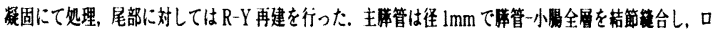
ストチューフとして3Frアトムチューフを留置した。標本は7 $\mathrm{cm}$ 大で敬を有し内部には出血や壊死を

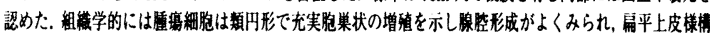

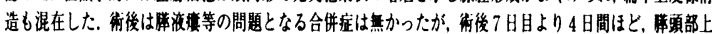

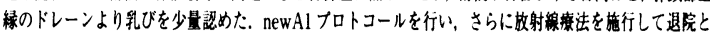

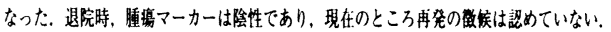


PPB-3-097 滕腺房細胞㿋の 2 例

川口義弥, 土井隆一郎, 藤本康:... 今村正之

(京都大学大学院腫鵿外科学)

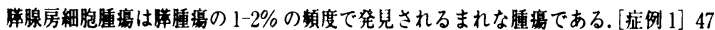

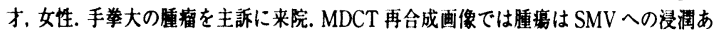
ク. MRCP では主席管の途䊉あり。血管造影では PSPD を feeder とし, tumor stain + であった。 術前診断は, non functioning islet cell tumor, solid and cystic tumor, aci-

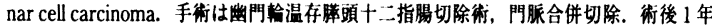

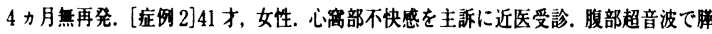

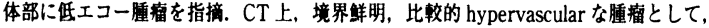
MRI では T1 : low, T2 ; high として描出された. non functioning islet cell tumor, solid

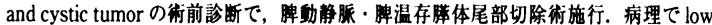

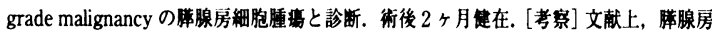
緗胞腫瓷は平均生存期間は 13 ヶ月. 画像訩断上 non functioning islet cell tumor

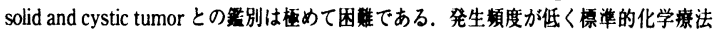
か設定されず，現時点では術前より本疾患を念頭においた外科治㞠が重要。

PPB-3-098 術後短期で再発し急速に增大した巨大膡未分化癌の一例 田口朋洋, 相垣時夫, 大绳浩久, 井上和人, 高山忠利

(日本大学第 3 外科)

急速に進行し、術後短期でリンパ節転位, 肝転移を来した巨大未分化滕蝠を経 駼したので都告する。症例は 51 藏男性. 平成 15 年 8 月より腹部鈍痡, 体重減 少が生じ始めた．增悪煩向にあるため11月に近医を受診。精查の結果，勝瘦 と診断されたが、全身状態が悪化し当科入紹介，緊急入院となった，腹部 CT 上, 腫場は $170 \times 85 \times 195 \mathrm{~mm}$ と巨大であり第 3 病日に腫准摘出術，羘脾合併切 除，左半結腸切除，空腸部分切除術を施行した，病理では，細胞は，大型の類 円形核を有し円形から多角形, 淡好酸性の広い細胞質を持つ細胞であった. 免 疫染色では, $\operatorname{keratin}(+), \operatorname{EMA}(+), \operatorname{CD} 34(-), \operatorname{CD} 30(-), \operatorname{LCA}(-)$. HMB45 (-)，s-100(-)，chromogranin (-)，であり，以上から非小細胞 性, 上皮性の未分化痘と診断された。術後 18 日目の腹部 CT にて, 腾頭部に $16 \times 13 \times 55 \mathrm{~mm}$ のリンパ節腫脤を認めたか，その後急速に増大し，術後 27 日には $78 \times 45 \times 105 \mathrm{~mm}$ となり,腹膜播腫, 肝転移も認めた. 37 日目には $158 \times$ $122 \mathrm{~mm}$ となった. 全身状態は增婁し, 平成 16 年 1 月 19 日に死亡した.

PPB-3-099 当院における滕獎液性赛胞腺腫切除例の検討

矢澤直樹，今泉俊秀，飛田浩䊇，柏木宏之，石井正紀，堂脇昌一， 杉尾芳紀, 石過孝文, 大谷泰雄, 幕内博康

(東海大学消化器外科学)

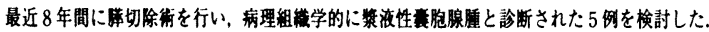

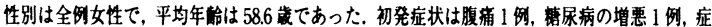

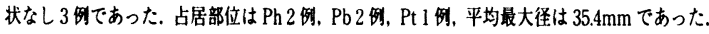

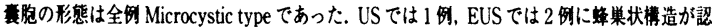

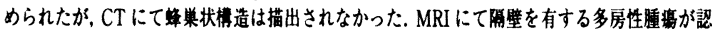

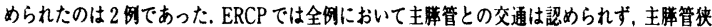

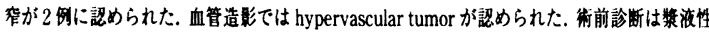

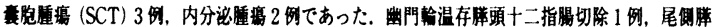

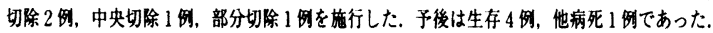

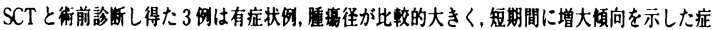

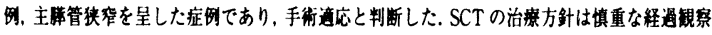

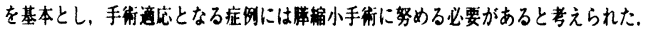

PPB-3-100 組織学的門脈浸潤を認め長期生存した膡頭部癌の 1 例と $2.5 \mathrm{~cm}$ 以下の小滕的の検討

吉松軍平, 中郡聡夫, 木下 平, 小西 大, 高橋進一郎

(国立がんセンター東病院上腹部外科)

今回我々は組穖学的門腺浸洞を認めた滕䫓部瘦に対してPPPD 及び門腺合併切 除を行い長期生存した 1 例を経糇したので，当院における $2.5 \mathrm{~cm}$ 以下の小勝被の 検討と併せて報告する. [症例] 52 葴，男性. 【主訴】上腹部有及び黄疸. 【現病 歴】1994 年 1 月より上腹部痛が出現. 1994 年 6 月より黄疸が発症し近医を受診,

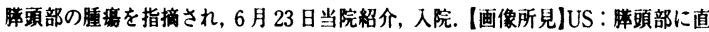
径約 $2.4 \mathrm{~cm}$ の腄痽を認め, MPD 及び CBD の拡張を認めた. CT ：羘碩部に直径約

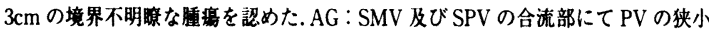
化を認めた【人院後経通) 6 月 23 日 PTCDを行い，7月11日滕癌の診断にて PPPD 及び門腺合併切除, IORT (20Gy) を施行した。 (病理所見) Ph, TS2 (23x $21 \times 20 \mathrm{~mm}$ ), mixed type, T4, poorly differentiated tubular adenocarcinoma, ch 3, du3, s0, rpl, pvl, a0, pl0, INFß, ly1, v3, nel, mpd (b), nl, stage IVal術後経通] 特に問題なく, 飠院. その後 109 力月を経て現在無再発生存中である.
PPB-3-101 Lymphoepithelial cyst of the pancreas の術前画像所見の 検討

大沼 淳, 稲垣光裕, 小原充裕, 山崎弘貴, 斉藤环已, 石崎 彰, 紀野修一，葛西真一

(旭川医科大学第 2 外科)

（目的～Lymphoepithelial cyst of the pancreas（以下 LECP）は，售胞内脄面に扁平上皮，上皮下にリン

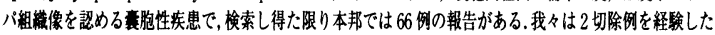

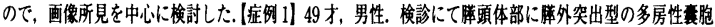

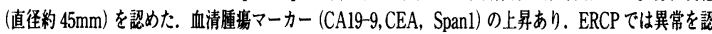

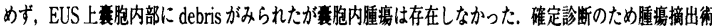

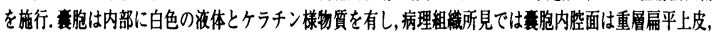

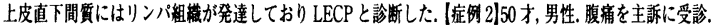

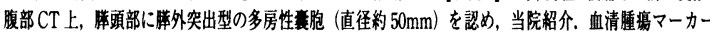

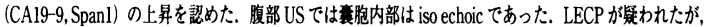

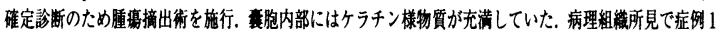

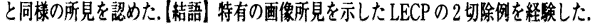

PPB-3-102 術前 IPMT/MCT と診断された Lymphoepithelial cyst of the pancreas $の 2$ 切除例

山下洋市, 福澤謙吾, 木下忠彦, 江口 博, 遠藤裕一, 竹中朋裕, 小森陽子, 甲斐秀信, 若杉健三

(大分赤十字病院外科)

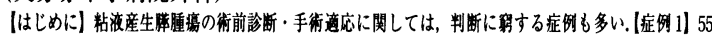

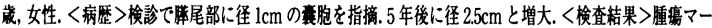

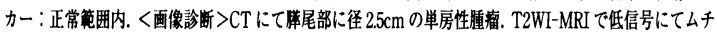

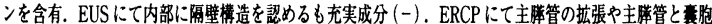

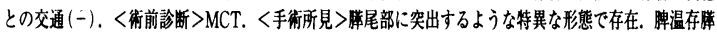

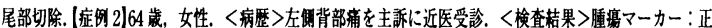

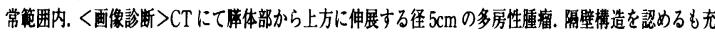

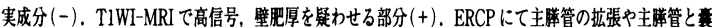

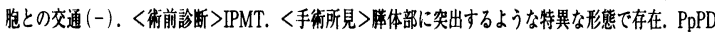

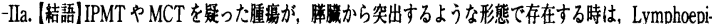

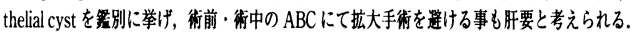

PPB-3-103 豚腫瘍の滕液による術前遺伝子診断

嶋本哲也, 横山省三, 谷 冥至, 川井 学, 寺澤 宏, 岩橋 諴, 内山和久, 山上裕機

(和歌山県立医科大学第 2 外科)

【目的】膡腫瘍患者の膡液中細胞の癌関連遗伝子の発現を定量することで, 癌の存在を術前に診断する指標となり得るか検討した. 【方法】術前に ERP で滕液を探取し手術を施行した 5 例（滕管癌： 2 例，IPMT adenocarcinoma：2 例, IPMT adenoma：1例）を対象とした. Real-time RT-PCR を施行し， CEA mRNA 量と CEA/GAPDH mRNA 比を検討した. また， 羘液中と末梢血中の CEA, CA19-9 值の測定および腪液細胞診もあわせて 施行した.【結果】対象の 5 例中, 䐙液細胞診が陽性であったのは羘管癌の 1 例のみであった(陽性率 25\%)，5例とも CEA mRNA 量, CEA/GAPDH 比, 羘液中 CEA 值はコントロールに比べて高く, adenocarcinoma と adenoma には差を認めなかったが, 膡液中 CA19-9 および末梢血中 CEA 值は adenomaでは低かった!結論】羘液中 CEA と亚液中 CEA mRNA を定量 することにより，癌の存在診断の正診率向上の可能性が示唆された。

PPB-3-104 制限增殖型アデノウイルスによる苇荿がんの微小転移診 断と治療の可能性

阿部 永, 元井冬彦，乙供 茂，大村範幸，砂村眞琴，福山尚治， 江川新一, 武田和憲, 松野正紀

(東北大学大学院消化器外科学)

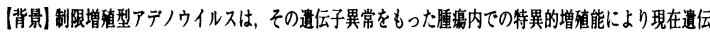

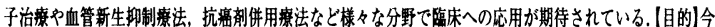
回我々は，制限增殖型アデノウイルス(AxE1AdB, AxdAdB-3)を用いた Navigation Surgeryへの応用

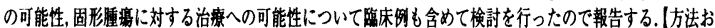

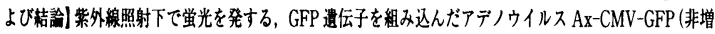

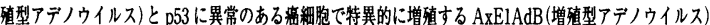

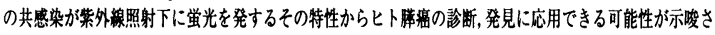

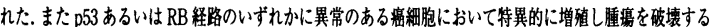

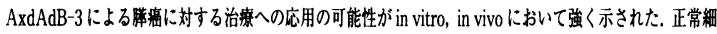

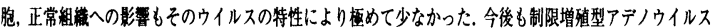
を用いて洎本への底用を目票に样々な分野での応用を探っていきたいと考えている。 
PPB-3-105 滕病変に対する造影超音波検査の検討 鈴木修司, 原田信比古, 田中精一, 林 恒男, 鈴木 衛, 羽生富士夫 (八王子消化器病院外科)

【目的】造影超音波検查にて腫場の組䅧学的所見の予測に利用できる可能性を認めたの で報告する. 【方法】対象は 2001 年 7 月から 2003 年 12 月までに本検査を施行した羘癌, 羘 IPMT 患者 23 例で，内訳は湔癌 14 例，滕 IPMT9 例である. 造影超音波検查所見と 標本との対比の検討を行った. [成績] IPMT は 9 例で壁の造影効果は港染 5 例, 不染 4 例で, 壁の隆起を認めた症例は 3 例であった，切除例は 6 例であるが, 壁の浱染した症 例 3 例は病理で papillary-mucinous adenoma であった. 不染の 3 例は病理上溓染した 症例との差は認めなかった。膵癌症例は 14 例で造影所見から 3 型に分けられ，不染が 8 例, 部分的浱染は 6 例, びまん港染は 1 例であった，切除例は 8 例で, 不染 5 例, 部 分的溓染 2 例, びまん浱染 1 例で全例 tubular adenocarcinoma であった. 組織との比較

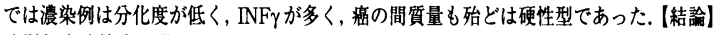
造影超音波検查で䐙 IPMT の adenoma 症例は壁の涱染, 壁の隆起の局在が明らかで あった。荤癌症例は 3 型に分類され, 濐染例は分化度が低く, INF $\gamma$ や硬性型が多かった。 造影超音波検査は組織学的所見の予測に利用できる可能性が示唆された。

PPB-3-106 膡腫瘍の術前検查としての PET の有用性の検討 小田切範晃"，添田純平"，岸本浩史"，千須和寿直"，河西 秀”， 大森敏弘", 田内克典", 小池秀夫", 小口和浩 ${ }^{21}$

(相澤病院消化器外科", 相澤病院 PET センター2)

[目的】 ${ }^{18}$ FDG-PET (以下 PET) の勝腫場の術前診断における有用性をCT と比較し検

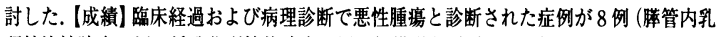
頭粘液性腺癌 2 例, 低分化型管状腺癌 1 例, 組織学的確診なし (非切除, 不明) 5 例) (手術 5 例, 非手術 3 例), 良性腫演は 5 例 (粘液性䧶胞腺腫 1 例, 羘管内乳頚粘液性腺 腫 1 例, 組織学的確診なし 3 例) (手術 2 例，非手術 3 例)であった. PET での原発巣の 検出は悪性腫湟 7 例 $/ 8$ 例 (感度 $87.5 \%$ ), 良性腫毫 0 例 $/ 5$ 例 (特異度 $100 \%$ ), であり, CT での検出は悪性腫場 7 例 $/ 8$ 例 (感度 $87.5 \%$ ), 良性腫場 4 例 $/ 5$ 例 (感度 $80 \%$ ) であっ

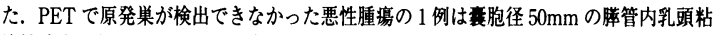

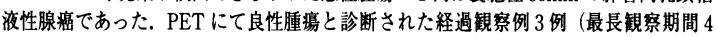
年)はいずれも現在まで経過良好である.【結論勝腯演の診断において PET は組織学的 確診がつかない症例の治療方針決定に際して有力な情報を提供できると思われた。だ し萁胞状䭪宿については鹤陰性を示すことがあり注意を要すると思われた。

PPB-3-107 膡頭部癌のリンパ節転移状況の検討

上田順彦, 川崎磨美, 古屋 大, 中川原寿俊, 吉光 裕, 澤 敏治 （国立福井病院外科）

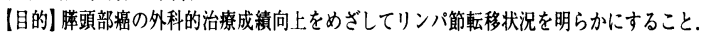
【対象】開腹手術がなされた滕頭部癌 24 例. 成績】(1) 手術: 腾切除術は 20 例（切除率 $83 \%$ ). (2) リンパ節転移陽性頻度：D2 以上の郭清 17 例中 $\mathrm{pN}$ 陽性 13 例，陰性 4 例。 (3) $\mathrm{pN}$ 陽性例 (13 例) の転移陽性部位と類度：1 群転移陽性 13 例 (100\%) で No.13 転移变 $92 \%$, 2 群転移陽性 8 例 (62\%) でN 0.14 転移率 100\%，3 群転移陽性 5例 (38\%) でN No.16 転移率 $100 \%$. (4) N 0.13 と 16 リン八節転移の関係：No.13 転移陰性 5例は 16 転移陰性. No.13 転移 陽性 12 例中 16 転移陽性は 5 例, 陰性 7 例. No.16 転移陽性は 13 転移陽性例のみであった。 (5) No.16 転移陽性 (5例) の検討：術中 No.16転移除性例（3例）の組䋨学的 No.16転移個 数は 1 個で，術中 N 0.16 転移陽性例 (2 例) は摘出りンパ節の大多数に転移を認めた（6）予 後： pN0（4例）は最長 4 年 11 か月, $\mathrm{pN} 1(5$ 例) は最長 2 年 10 か月, $\mathrm{pN} 2$ 以上は最長 1 年 2 か月であった. [結論] (1)リンバ節転移は D2 以上の郭清例 17 例中 13 例に認め, No.13 転移は $92 \%$, No.14は $62 \%$, N 0.16 は $38 \%$. (2) No.13 リン八゚節は No.16リンバ節へのの転移を 予測する key node である. (3) p N $0, \mathrm{~N} 1$ 例で各々 4 年または 2 年以上生存可能であった。

PPB-3-108 術中に切除不能と診断された膡癌の臨床病理学的検討 千葉斉一, 相浦浩一, 伊藤康博, 林田 哲, 河地茂行, 田辺 稳, 若林 剛, 島津元秀, 上田政和, 北島政樹 (慶應義塾大学外科)

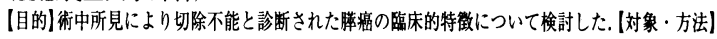
1971 年 5 月加 2003 年 8 月までに，術中所見により非切除となった滕㿋 25 例と，切除症例 207

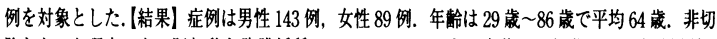

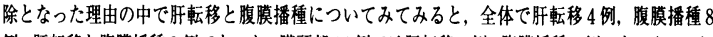

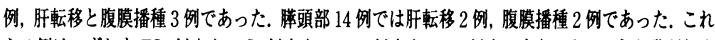

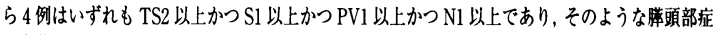
列全体の中で肝転移・腹膜播種により非切除となった症例は $10.8 \%$ であった。一方，羘体尾部 11 例では肺転移 2 例, 腹膜播種 5 例, 肝転移と腹膜播種 4 例と全例か遠隔転移により非切除となっ た.これらの症例はいずれも TS2 以上かつ PV3かつ A1 以上であり，そのような䐙体尾部症例全

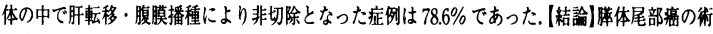

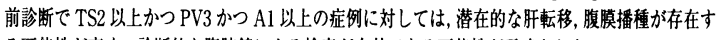
る可能性が高く，診断的な腹腚鏡による検索が有効である可能性が示晙された。
PPB-3-109 Groove 領域满瘦の進展形式とその病理組織学的検討 梶原正俊, 和田道彦, 松本逸平, 小林裕之, 岡裘幸, 正井良和。 宮原勅治, 橋本 隆, 細谷 完, 梶原建熙 (神戸市立中央市民病院外科)

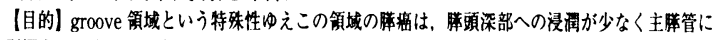

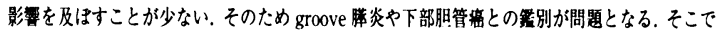

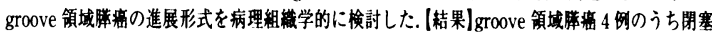

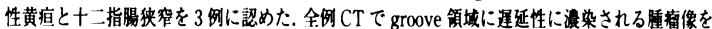

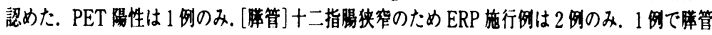

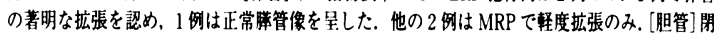

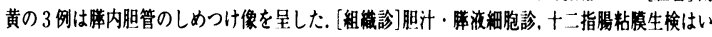

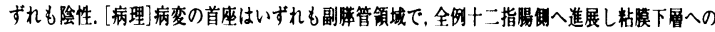

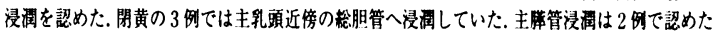

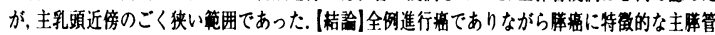

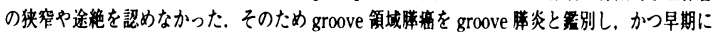

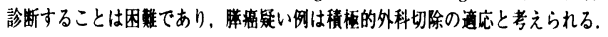

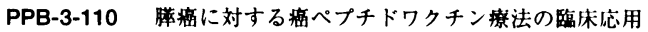
山本光太郎"，河岡 徹"，上野富雄"，伊東恭悟2'，岡正朗 (山口大学第 2 外科"，久留米大学免疫学"

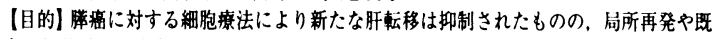

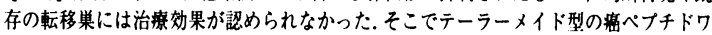

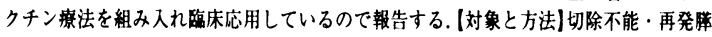

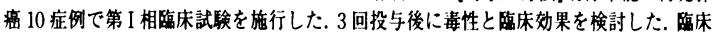

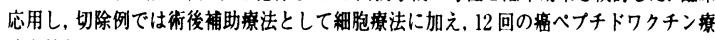

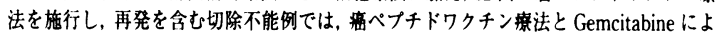

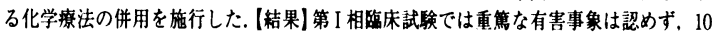
例中 3 例が NCで，全て腹胵内リンバ節再発例であった１例は28 ケ月間のlong NC である。臨床応用では，切除例ではStageIVal 例が QOL 良好に術後14 ケ月経通した が, 術後 15 ケ月め骨転移で急死した，切除不能例では局所再発 1 例か。局所再発からの 出血は沈静化し，腫瓷マーカーの低下を認めたか，治寮開始後 7 个月に他病死した、結

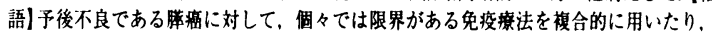
化学療法と併用したりすることで,より强力な治療となる可能性が示㥖された。

PPB-3-111 局所進行滕癌に対する周術期肝動注化学療法の意義 金光敬一郎"，高森鳘史"，辻 龍也"，近本 亮"，草野秀一", 平岡武久 (熊本大学医学部附属病院消化器外科", 九州看讙福祉大学 ${ }^{2 \prime}$ )

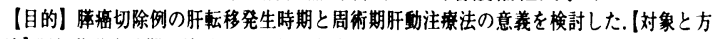
法了肝転移発生時期の検討には拡大郭清手術 + IOR 例の治甞切除例 10 例を対象としCA 19-9を追跡し，肝動注廉法の検討では 1994 年から 2003 年の滕管素切除例 stageIII 以上 60 例（非動注群 49 例，動注群 11 例) 老对象に早期予後, 肝転移出現の有無、肝転移出

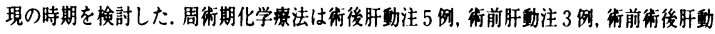
注を 3 例に持繶動注で道 5 日動注 2 日休莱で $5 \mathrm{FU} 250 \mathrm{mg} /$ 日を行った. (結果)術後 CA19 -9值は右方上がりで0点は殆どが術前で術前からの微小胿轻移の存在が示睃された。 術

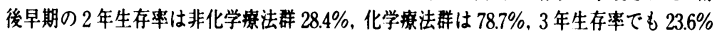

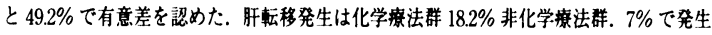
事に差はなかった。発生時期は動注群術後平均 374 日目で非動注群は200日目で，動注群

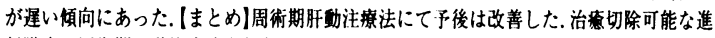

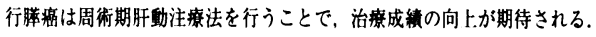

PPB-3-112 腾体尾部癌に对する姑息切除+術後補助㫫法の有用性 武田 裕", 蓮池康德 ${ }^{13}$, 柏崎正樹", 道田知樹 ${ }^{2}$, 池田昌弘 ${ }^{2}$, 辻仲利政

(国立病院大阪医療センター 外科"，国立病院大阪医療センター 消化器科 ${ }^{2}$, 兵庫県立.西宮病院外科 ${ }^{31}$ )

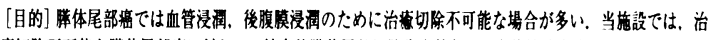

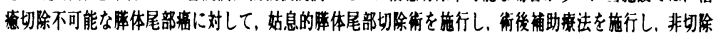

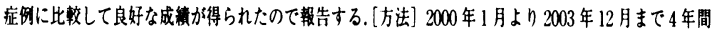

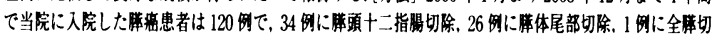

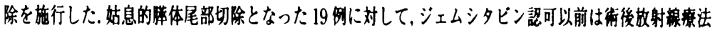

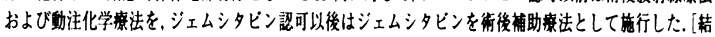

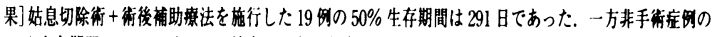

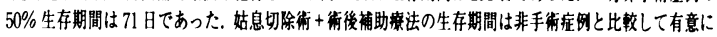

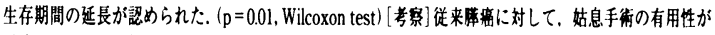

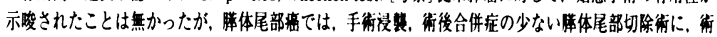

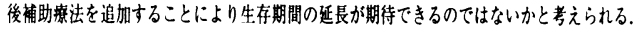


PPB-3-113 局所進行羘痹に対する術前化学曢法併用拡大手術の治療 成績

伊佐地秀司, 水野修吾, 曰讲正信, 小川朋子, 楼井洋至, 田端正己, 山際煡太郎, 横井, : 1 本伸

(三重大学第 1 外科)

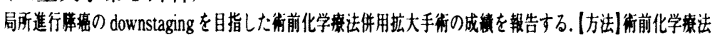

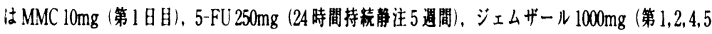

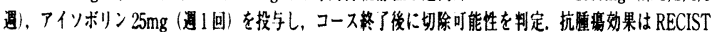

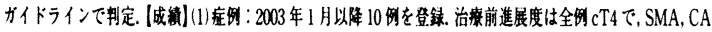

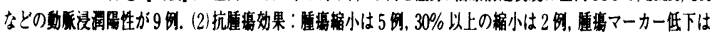

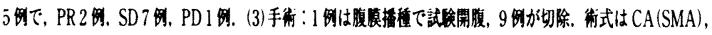

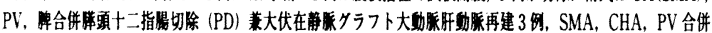

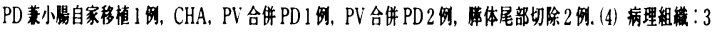

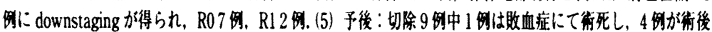

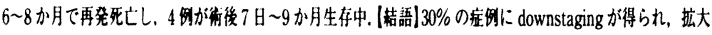

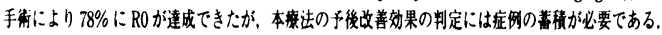

PPB-3-114 局所進行䐙癌に対する neoadjuvant 療法による downstage operation $の$ 可能性

田岡大樹, 信岡柨, 山下雅子, 谷川健次, 吉峰修時, 今井俊皘 (鈴鹿中央総合病院外科)

【目的】局所進行滕癌 (cStageIVb)に対する neoadjuvant Rx. (NAR) の効果 と down stage operation (DSO) の可能性を明瞭にする.【対象】 M0で cStageIVb の浸洞性愺管㿋 5 例 【方法] CT と staging laparoscopy にて進行度 判定. 主腫堭の造影効果 (CT-EM) を 3 群に分類 (Grade 1: 腫场像不明䧆,

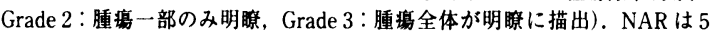
$\mathrm{FU}+\mathrm{LV}+\mathrm{MMC}+\mathrm{GEM}+$ Dipirydamole + heparin. 効果判定は RECIST 施 行. またCA19-9 娍少率評価. 切除例は組織学的化学療法効果判定. さらに NAR 著効例の術前 CT-EM を再評価.【結果】 全例 PR であり平均腫場縮小率 $45 \%, \mathrm{CA1} 19-9$ 全例低下 (平均娍少华 $59 \%$ ). NAR に一 s-Stage III (2 例), s -Stage IVa（1 例）となり 3 例に DSO 施行. 病理\&CT-EM 所見から Grade

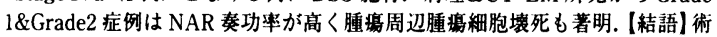
前にNAR 効果を持つ局所進行腾䄽と DSO 叮能となる症例が予測可能.

PPB-3-115 愺澏術後再発症例に対する GEM + UFT 療法の成縝 岡田邦明, 近藤征文, 石津寛之, 益子博幸, 田中浩一, 秦庯壮, 川村秀樹, 菊地一公, 植村一之, 横田良一

(厚生連札㹸厚生病院外科)

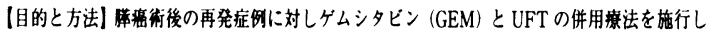

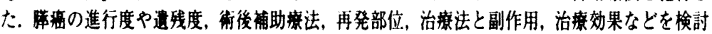

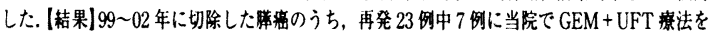

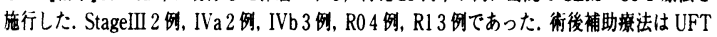
と十全大補湯が投与され，RIの3例には $5 \mathrm{FU} 500 \mathrm{mg} / 2 \mathrm{wks}$ が追加された，再発部位は後腹膜

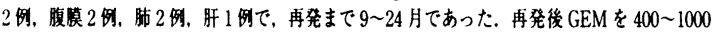

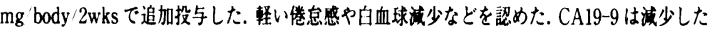

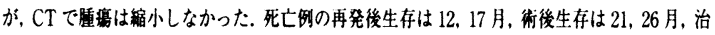

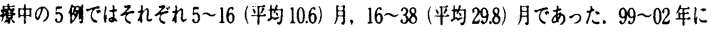

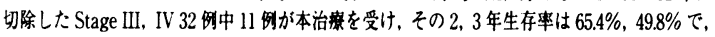
95 98 年 (31 例)の38.7\%，25.8\%より改善された. [結吾] GEM+UFT 新法は外来通院で可 能でQOLを摃なうことなく，生存期間を延長し再発例の治榇として有効である。

PPB-3-116 当科における進行・再発滕瘦に対する gemcitabine 動注 療法について

辻 宗史, 仁尾義則, 山儿和盛, 小池諴, 橋本幸值, 板倉正幸,

矢野誠司, 桶上哲哉

(島根大学第 1 外科)

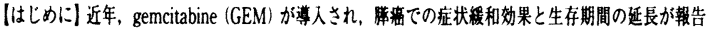

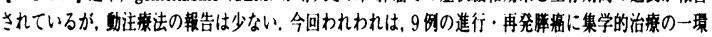

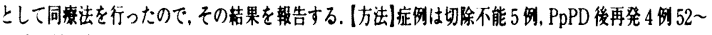

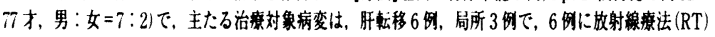

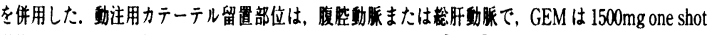

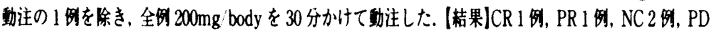

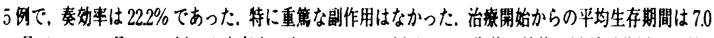

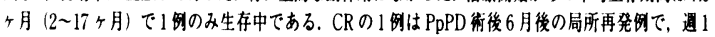

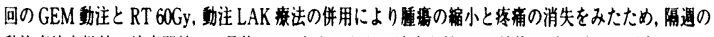

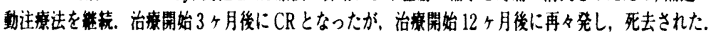

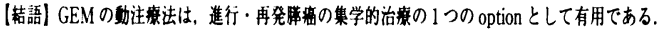

PPB-3-117 インターフェロン治療により C 型肝炎ウイルス陰性化後 に発症した肝細胞癌 5 例の検討

森田圭介, 岡本好司, 吉田陽一郎, 鶴留洋輔, 平田敬治, 日暮愛一郎, 中山善文, 小西鉄已, 永田直幹, 伊藤英明 (産業医科大学第 1 外科)

IFN 治療にてC 型肝炎ウイルス陰性化後, 肝紐胞癌を発症し根治切除した5例を経験した。 (症例 1) 67 歳，女性. 平成 4 年 5 月 INF 療法. ウイルスは再度陽転化，同 14 年 5 月 INF, リバビリン併用療法開始, 11 月 HCV 除性. 経過 1 年後肝 $\mathrm{S} 2$ に腫痹認め, 手術施行 T1N0 MOStageI. (症例2) 65 歳, 男性. 平成 14 年 3 月 IFN 療法施行L同年 9 月 HCV 陰性化. 1

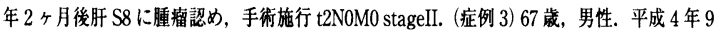
月 IFN 寮法施行. 平成 6 年 1 月 HCV 陰性. 5 年 5 个月後, 肝 S5 亿腫痛認め, 手術施行 $\mathrm{t} 3$ NOM0 stageIII. (症例 4) 65 嵅, 男性. 平成 5 年 3 月に IFN 療法施行. HCV 陰性. 5 年 8 ヶ 月後肝 S4 に腫痽認め, 手術施行 t2NOM0 stageII. (症例 5) 48 歳, 男性. 平成 5 年 11 月

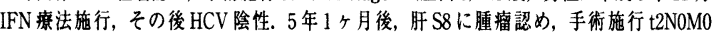
stageII. 現在全例, 無再発生存中である. (結語)IFN 療法の完全著効例においても, 長期経 過観察が必要であり，発瘦症例には積極的な肝切除術が可能であると考えられた。

PPB-3-118 C 型肝硬変に発生した成人肝芽腫の 1 切除例 工藤啓介 ${ }^{1: 22}$, 別府 透”, 杉山眞一", 石河隆敏", 田中秀幸", 辛島龍一"，川口 哲"，江上 寛”

(熊本大学大学院医学薬学研究部消化器外科", 熊本赤十字病院内科 ${ }^{21}$ ) 【はじめに成人肝芽腫は㰌めてまれである。今回われわれはC型朋硬変に発生した成人肝乎腫

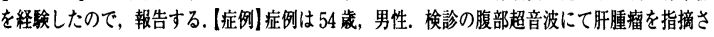
れた. HCV 抗体陽性, 腫第マーカーでは AFPが $301 \mathrm{ng} / \mathrm{ml}, \mathrm{AFP}-\mathrm{L} 3$ 分画が $72.5 \%$ と上年して

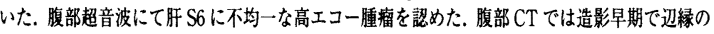
みが淡く enhance された. 腹部 MRI では T1 強調画像で low, T2 強調画像で high intensity の mixed patternを呈していた. 以上より, 混合型䏕㿋の術前診断にて肝後区域切除術を施行し

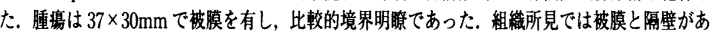

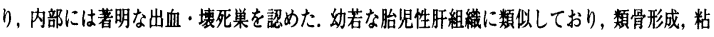

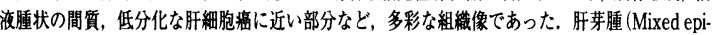
thelial and mesenchymal type) の最斜診断であった. 背景肝は肧硬変 $(F 4, A 2)$ であった. 組 的な門腺浸洞を認めたため, CDDP 50m, Farmorbicin 30mgによる術後補助䏕動注化学療 法を行った，術後約 10 ケ月の現在も無再発生存中であり，腫眗マーカーは正常化している。

PPB-3-119 高齢者に認められた肝芽腫の一例 穴澤貴行, 斎藤拓朗, 土屋貴男, 佐藤佳宏, 見城 明, 星野実加, 斎藤隆晴, 後藤満一

(福島県立医科大学第 1 外科)

肝芽腫の成人発症例はきわめて稀で治療法は確立されておらず, 肝紏胞癌に準じた治 療法が選択されているが, その予後は不良とされている.我々は高粭者女性に発症した 肝芽腫の一例を経験したので報告する. 症例は 73 歳の女性. 検診で肝右葉に腫㿔を指 摘され，近医で精查を受け肝綀胞癌と診断された，手術予定となり自宅で待機していた が,肝腫場破裂による出血性ショックをきたし当院へ救急搬送された.補液にて血圧が 安定し, 祭急血管造影を行い出血に関与する肝動脈の塞栓術を施行し止血した。全身状 態が安定した時点で, CT 上肝右葉の腫啺は単発かつ腹水貯留など腹膜播種の所見を 認めないため, 手術を施行した。開腹時に腹膜播種性転移の所見を認めず, 肝右葉切除 ならびに横隔膜合併切除術を施行した。腫瘍は出血と壤死を伴う多結節瘾合型で, 病理 組蟣所見では上皮性と間葉系の腫㑥成分からなる肝芽腫との診断であった。術後経過 は良好で, 術後 4 ヶ月の現在, 無再発生存中である. 本症例では抗癌郕感受性試験の結 果をふまえ，CDDP と GEM の組み合わせによる術後化学療法を施行している.

PPB-3-120 バルブロ酸ナトリウム長期服用中に発症した大型高分化 肝細胞癌の 1 切除例

吉田 淳, 袴田健一, 十束英志, 豊木嘉一, 原豊, 青木計績, 鳴海俊治, 吉原秀一, 佐々木睦男

(弘前大学第 2 外科)

【はじめに $3 \mathrm{~cm}$ 以上の高分化型肝緗胞癌は稀であるが， $5 \mathrm{~cm}$ を越える大型高分化型胿細胞癌 (Large well-differentedHCC : LWHCC) が経输されることがある. 今回バルフロ酸ナトリウム長 期服用中に発症した LWHCC の症例を経倹したので報告する. [症例]28歳, 男性. 21 歳時よりて んかんでバルフロ酸ナトリウムを服用。肋機能異常を指摘され，超音波梌査で肝右葉に，80 mm

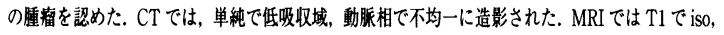

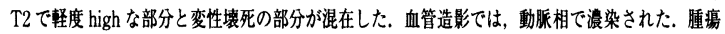

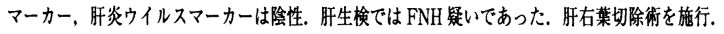

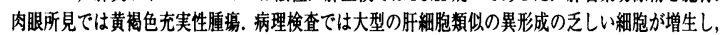
LWHCC と診断された（考察】肝緗胞㿋と抗けいれん郕服用に関連があるとされる報告例は小数

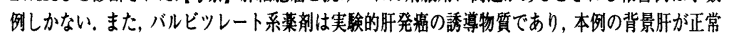
であることから，本症例においては抗けいれん郕服用と LWHCC 発症の関連が推察された。 
PPB-3-121 経口避妊薬長期内服歴のある女性に発生した中心性疫痕 を伴った肝細胞癌の 1 例

森 光生 ${ }^{1}$, 山田洋平", 片野智之 ${ }^{1}$, 山本健太郎", 関 博章 ${ }^{1}$,

亀谷武彦"), 里 俤子 2 (

(けいゆう病院外科", けいゆう病院病理")

症例は経口避妊薬および胎整抽出製郕投与の既往がある 40 歳女性で, 腹痡を主訴として 当科紹介となった. $\mathrm{HBs}$ 抗原陰性, 血中 $\mathrm{HCV}$ 定量測定では検出感度以下であった. 画像診

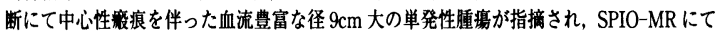

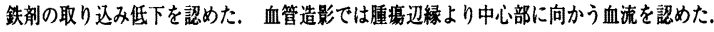
PIVKA-IIが $27400 \mathrm{mAU} / \mathrm{ml}$ と高值を示し HCC と術前診断したが, 腺脾や fibrolamellar variantの可能性を考虑し, 開腹術を行った. 肝 $S 4-5$ の下緑より訮外性に発育する径 $9 \mathrm{~cm}$

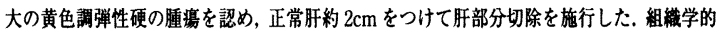

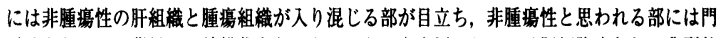
脈域を認めた. 背景肝に線維化を認めなかった。本症例においては肪細胞落として典型的 ではない部分が多く，その病因として経口避妊薬およひ胎整抽出製郕への暴露の関与が推 察された，通常の肝細胞痹とは異なった発㿋過程を経て出現した可能性が示唆される。

PPB-3-122 NASH に合併した肝細胞癌の 3 症例

菊地勝一"1), 村山道典", 相原 司", 安井智明", 光信正夫",

山中若樹1), 杉原綾子 2 (1)

(明和病院外科"), 明和病院病理")

【目的】今回我々はNASH から肝細胞稻に移行したと思われる 3 手術症例を释験 したので報告する.【対象, 方法】 我々の施設で 2 年 9 ヶ月間に非 B 非 C 型肝細胞 瘦の手術症例は 17 例であり，このうち非アルコール性は 12 例, 内 NASHは 3 例であった. (症例 1) 68 歳男性, 糖尿病を合併. 肝 S5+S6 切除術, マイク口波凝 固術 $(\mathrm{S} 4, \mathrm{~S} 8)$ 施行, 病理組織所見は, 多中心性肝絊胞㾂 $(\mathrm{S} 5, \mathrm{~S} 6, \mathrm{~S} 4, \mathrm{~S} 8)$ Chronic Hepatitis F1A1 であった. (症例 2) 54 葴男性. 右開胸開腹肝 S7+S8 切除術, マイ ク口波凝固術 (S4) 施行, 病理組織所見は, 多中心性肝細胞㿋 (S7, S8, S4), Chronic Hepatitis F3A1 であった（症例 3)69 歳男性, 榶尿病, 高脂血症, 肥满を合併. 肝 S4 切除術, マイクロ波凝固術 $(\mathrm{S} 7, \mathrm{~S} 8)$ 施行, 病理組織所見は, 多中心性肝細胞痹 (S4, S7), Liver Cirrhosis with NASH であった. [考察]我々は最近 2 年 9 ヶ月間に NASH に肝細胞癌を合併した 3 手術症例を経験した．NASHに合併した肝細胞癌 はウイルス性肝細胞癌同粎, 多中心性発癌が多いことが示唆された。

PPB-3-123 脾機能立進症に対する部分的脾塞栓術により切除可能と

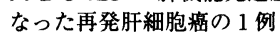

戸田桂介, 稲垣 優, 岡 哲弘, 吉田亮介, 常光洋輔, 大塚㣀哉,

三好和也, 大崎俊英, 淵本定義

(国立福山病院外科)

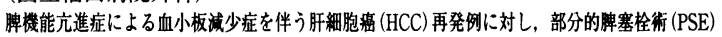

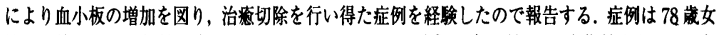
性, 以前よりB型慢性肝炎にてフォローされていた，平成 14 年 3 月 HCCを指摘され TAEを 行ったが, 平成 15 年 7 月再発を指摘され，入院となった。血管造影にて A8 末梢に tumor stain,

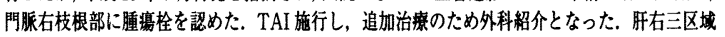
切除にて切除可能と考えられたが, 血小板 3.6 万/峛と著明な低下を認め, 手術のリスクが高い

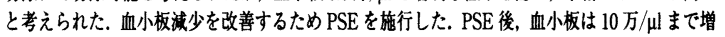
加し, 肝右三区域切除術を施行した. 術前後に血小板 50 単位を輸血したものの周術期を通して

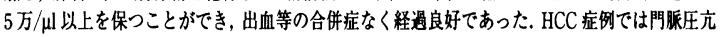

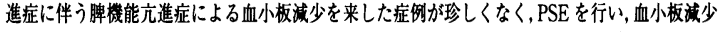
を改善することにより，安全に手術が行え，手術道応を拡大することができると考えられた。

PPB-3-124 体質性 Indocyanine green（ICG）排泄異常症を伴う胆管 細胞瘦の 1 手術例

中川基人, 金井歳雄, 高林 司, 坂田道生, 松本圭五, 関みな子, 中村 威, 今井 俊, 澤柳智樹

(平塚市民病院外科)

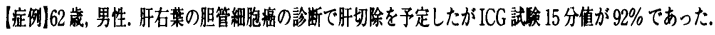

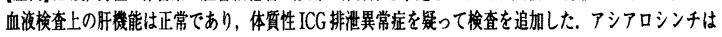
$\mathrm{HH}_{15}=0.559, \mathrm{LHL}_{15}=0.557$ と正常. AKBR 1.02 と正常. 固有肝動脈血流速度の resistance index 0.7

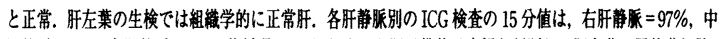

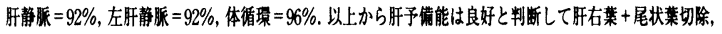

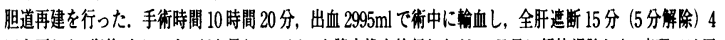

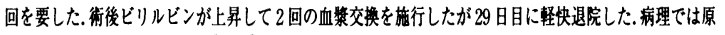

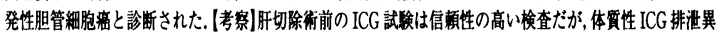

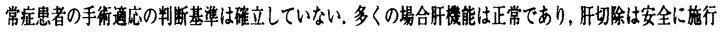

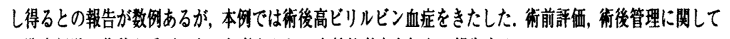

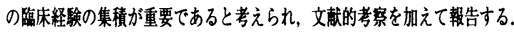

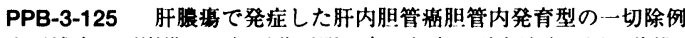
中野博史, 西真华一, 伊豆蔵正明, 奥邦彦, 吾妻達生, 岡 義雄, 宮崎 知, 西田幸弘, 酒田和也, 石丸和彦

(東大阪市立総合病院外科)

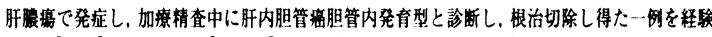

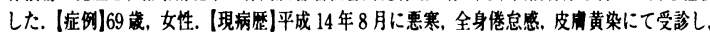

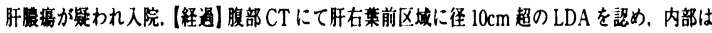

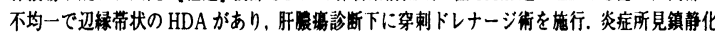

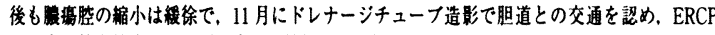

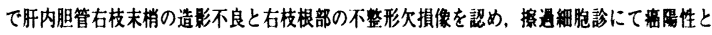

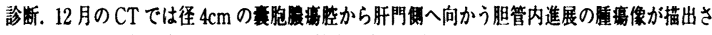

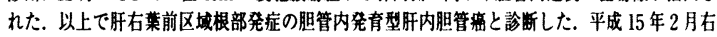

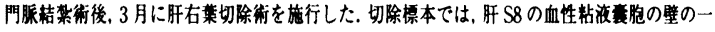

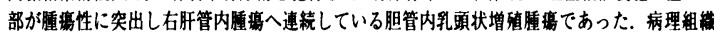
診断は Intrahepatic cholangiocellular carcinoma, intraductal growth type, well differentiated papillary adenocarcinoma であった. 患者は街後 10 ケ月の現在, 勄再発生存中である.

PPB-3-126 胸㓐内穿破を来たし救命し得た巨大アメーバ肝朖演の 1 例

孫敬洙”，遠山洋一"，良元和久"，渡辺一裕"，柏木秀幸"， 矢永勝彦"

(東京慈恵会医科大学柏病院外科"，東京慈恵会医科大学外科 ${ }^{21}$ )

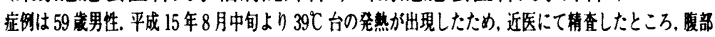

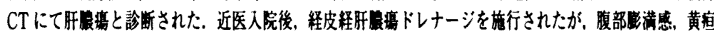

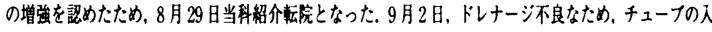

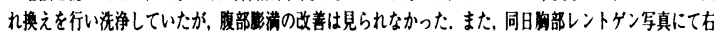

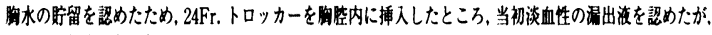

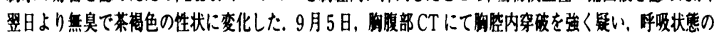

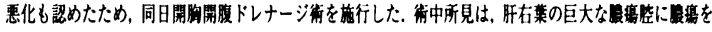

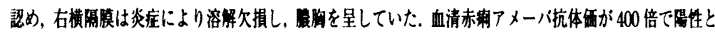

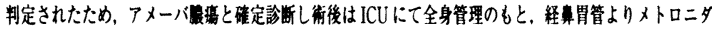

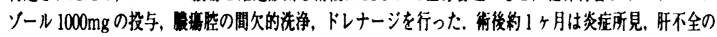

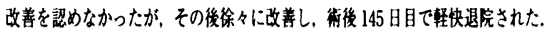

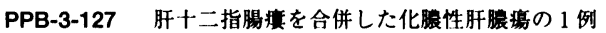

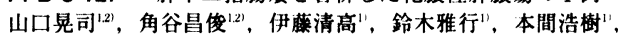
橋本正人

(北海道岩見沢労災病院", 北海道大学大学院腫湯外科 ${ }^{21}$ )

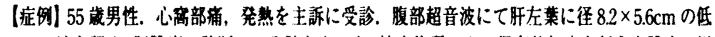

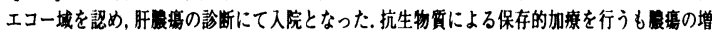

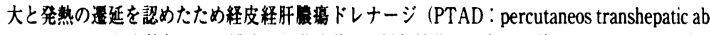

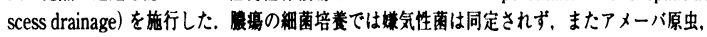

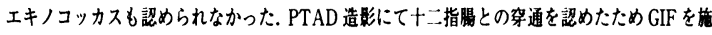

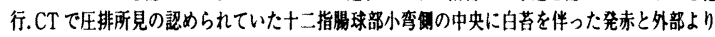

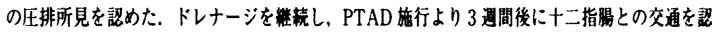

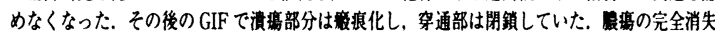

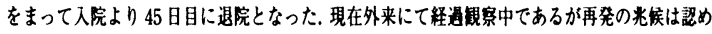

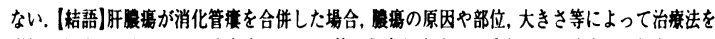

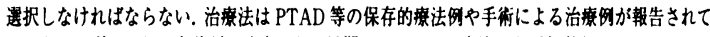
いるが、いずれにしても診断，治療のため早期のドレナージ潦法が必要と考えられる。

PPB-3-128 肝内胆管痗との術前鏗別診断が極めて困難であった肝内 結石症の一例

中島亮太郎, 寺嶋宏明, 小林裕之, 岡罒畫幸, 和田道彦, 正井良和, 宮原栜治, 梪本 隆, 細谷 亮, 暒原建熙

（神戸市立中央市民病院外科）

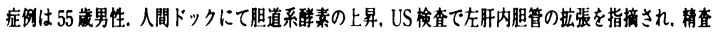

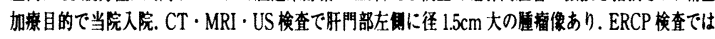

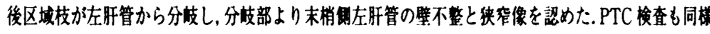

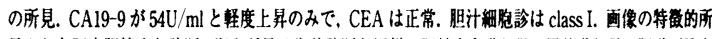

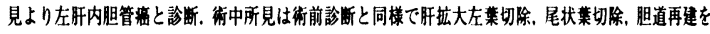

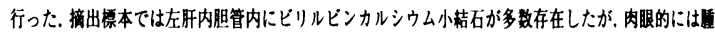

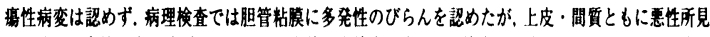

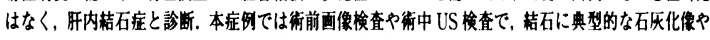

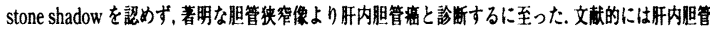

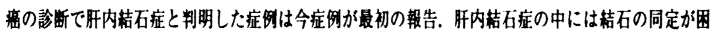

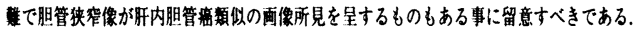


PPB-3-129 HCV 陽性の AFP 産生十二指腸釈肝転移の 1 例 小池大介，村瀬勝俊，器本強，近藤折矢，杉本玩截，田原憲一， 田島吾郎, 杉村啓:...郎, 尾関 豊。

(国立.東静病院外科)

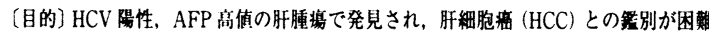

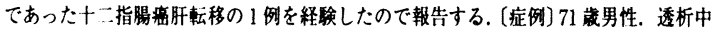

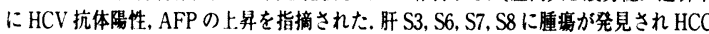

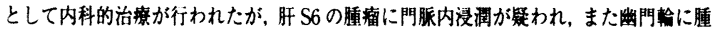

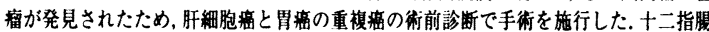
球部に母指頚大の腫嘴を認め，術中超音波では肝 S3, S6, S7にそれぞれ 2 4cm 大, 肝 S8には $3 \mathrm{~cm}$ 大の RFA 後の腫㾇を認めた. 肝 S6, S7 には右肝静脈に接した低エコー腫 鴻を認めた。手術は肝拡大後区城切除術と肝 S3 部分切除術, 胃は幽門部十二指腸球部 切除術とした. 切除標本の肉眼钼察で腫场は十二指晹球部に存在しており, 病理組織学

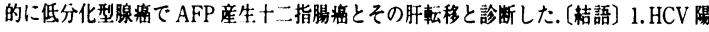
性の AFP 産生十二指晹癌肝転移の1例を経験した，2.HCV 陽性，AFP高值なため

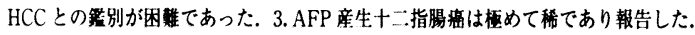

PPB-3-130 悪性胸腺腫の肝転移に対し肝切除を施行した一例 加賀谷暁子, 山本宏, 永田松大, 滝伸洗, 早田浩明, 伊藤泰平, 三浦世樹，浅野武秀，渡辺一罗

(千葉県がんセンター消化器外科)

【症例】 56 歳女性【主訴】特になし【既往歴】特記すべきことなし【現病歷】1993

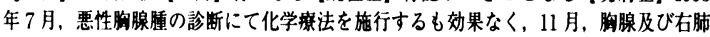
全摘出，上大静腺合併切除術を近医にて施行された。横隔膜残存病変に対し，術後放射

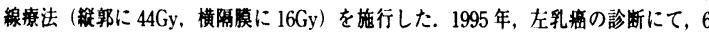
月 6 日左乳房切除術を施行した. 1999 年 6 月，腹部超音波にて肝 S7に $11 \mathrm{~cm}$ 大，S3

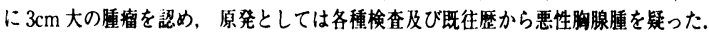
左肺転移も認めたが，発育が非常に縓徐であったため, 1999 年 8 月 17 日肝部分切除を 施行した，病理診断は胸腺腫の肝転移であり，乳癌の転移は認めなかった. 2000 年 8 月，第 2 胸椎転移を認め放射線㙩法を施行，その後，2003年 7 月 24 日肝再再発に対し 肝部分切除および Microwave 烧灼 (2 筒所) を行った. 2004 年 2 月現在, 肺転移に対 し、呼吸器科にて外来経過钼察中である.【結語】今问我々はまれな悪性胸腺腫の肝転移 に対する切除の一例を経験したので, 若干の文献的考察を加え報告する.

\section{PPB-3-131 肝細胞癌からの小腸転移の 1 例}

佐々木貴浩"，竹中能文”、川久保雅祥"，星川竜彦”，諏訪達志”， 内田智夫"，佐藤去喜"，古内孝幸"，佐久間汪祥"，堀㣀佐男” (水开赤十字病院外科"，水；赤十字病院病理検査科 ${ }^{21}$ )

<症例 $>82$ 歳男性. <主訴>埋色便, 筫血. <既往 $>2$ 年前, 肝細胞盘の診断にて左外僛 区域切除，横隔貘合併切除術施行. 〈現症>黒色便，へモグロビン $5.8 \mathrm{~g} / \mathrm{dl}$ まで低下する 負血を認め。会血目的で入院をした，上部，下部内視鏡で異常所見を認めなかった．CT

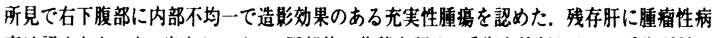
変は諗めなかった. 出血シンチで, 同部位に集皘を認め，手術を施行した。 〈手術所見〉

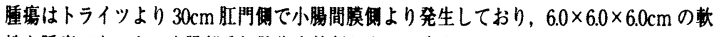
性な堙堭であった，小腸部分切除術を施行した．〈病理〉Metastatic hepatocellular carcinoma in the small intestine で䦪筋層直下より発生しており，ビリルビン産生の加 わった trabecular type, moderately differentiated hepatocellular carcinoma, Edmond-

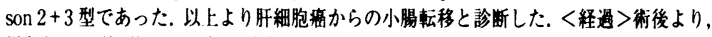
黑色便認めず, 負血も改善, 現在外来通院中である. 術後 2 年を経過した肝細胞笛からの 小腸転移を経绘したので稀有なる症例と考え，若干の文献的考察を加えて報告する.

PPB-3-132 UFT-E 併用 5-FU + CDDP 間欠的肝動注化学療法が著 効した術後再発肝粼のI例

齊藤 準, 土田明彦，小澤 隆，池田隆久，北村慶一，遠藤光史， 井上敬一郎, 青木達哉

(東京医科大学第 3 外科)

症例は 66 歳, 男性. 僈性C 型肝炎に対しインターフェロン㞠法にてウィルス除去後, 血友病

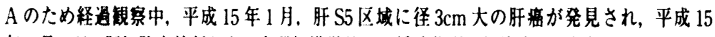
年 4 月 7 日, 肝切除を施行した。病理組菕学的には低分化型肝細胞凅で, 大きさ $55 \times 45 \mathrm{~mm}$,

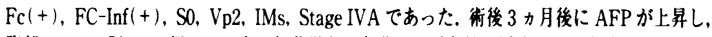
腹部 CT にて肝 S6 に径 $1.5 \mathrm{~cm}$ 大の転移巣と肝左葉に門脤左枝に腫場塞栓を伴うびまん性転 移を認めたため，肝S6の転移单にTACE，肝左菜にTAI，肝動注用カテーテル留置を施行 した. $5-\mathrm{FU}$ 持䄈肝動注 $(500 \mathrm{mg} / 24$ 時間, 5 日間投与, 2 日間休薬)を 2 クール施行後, UFT -E (300mg 日, 連日経口投与) 及び $5-F U(500 \mathrm{mg} /$ 间) +CDDP (10mg/回) (2 週每, 単回

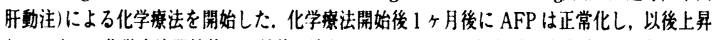
していない. 化学㫧法開始後 4 力月後の腹部 CT では肝 S6 の転移果は完全俵死, 肝左葉のび

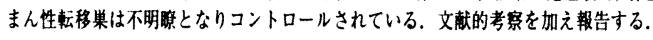

PPB-3-133超音波造影剂を用いた肝機能評価

廣田政志, 杉本博行, 金子哲也, 吳 成浩, 井上総一郎, 竹田 伸, 中尾昭公

(名古屋大学大学院病態制御外科)

く目的〉我々は肝硬変における肝内血行動態変化に着目して, 非侵襲的な肝硬変診断法と して超音波造影剤の門脈, 肝静脈到達時間較差(PV-HVTT)を湘定し，その有用性を報告 した.今回は PV-HVTTが肝機能評価の指標となりうるかどうかを現在術前肝機能評価と して広く用いられているChild-Pugh score, ICG-K 值と比較検討した. 〈対象と方法〉非 肝硬変 (nLC) 21 例 (正常 volunteer11 例, 慢性肝炎 10 例で全例 Child-Pugh score 5), 肝 硬変 (LC) 21 例 (Child-Pugh score 5/6/7/8/9:10/5/2/2/2 例) を対象とした. PV-HVTT は pulse inversion imaging を用いた超音波造影法にて測定した. ICG-K 值は pulse dye

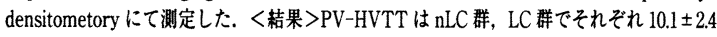

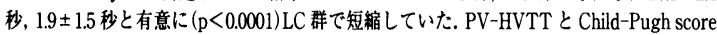
との間には有意な逆相関を示し $(r=-0.517, p=0.0009)$, PV-HVTT と ICG-K 値との間に は有意な順相関を示した $(r=0.628, p<0.0001)$ ．〈結語 $>$ PV-HVTT は有用な非侵襲的肝 硬変診断法だけでなく, 術前肝機能評洒の指標にもなりうることが示唆された.

PPB-3-134 肝予備能不良肝癌例に対する治療方針の検討 鳴海俊治", 袴田健一" ", 吉原秀-1", 十束英志", 豊木嘉一", 佐々木睦男", 坂本十一" ${ }^{2)}$, 須藤俊之 ${ }^{2)}$

(弘前大学第 2 外科 ${ }^{1}$, 弘前大学第一内科 ${ }^{2}$ )

【緒言】肝予備能不良肝癌例に肝切除術を施行した症例を検討し, またRFA 施行症例との比較 検討で若干の知見を得たので報告する.【対象】1989 2003 年にHCCにて ICGR15>30\% で初 回治撩として肝切除を施行した 20 例を対象とした。また 2000 年 4 月より HCCにて初回治療で RFAを施行したICGR15く50\% でかつ腫瘍が片葉，3個以内の 40 例と比較した!結果】平均の

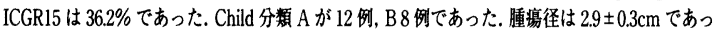
た. 平均手術時間は $198 \pm 13$ 分, 出血量は $1101 \pm 123 \mathrm{ml}$ であった. TW は $5.1 \pm 1.4 \mathrm{~mm}$ であった. 術後ビリルビンは $1.2 \mathrm{mg} / \mathrm{dl}$ の一過性の上昇（p<0.05）をみた．重篤な合併症や肝不全死はな かった. 予備能不良肝切除例と RFA 症例 (ICGR15 平均 $25.4 \%$ ( $\mathrm{p}<0.001$ ) との生存率の比較検 討では3年生存率でそれぞれ 73.7\%vs. $63.8 \%$ ，無再発生存率では $41.4 \%$ vs. $38.3 \%$ であった (N. S.). [考察] ICG15>30\% となる肝予備能不良例でも安全に手術が可能であった. 肝機能が良好 な RFA 施行症例に比しても良好な成績であり，個々の症例に応じて肝切除の適応を吟味し，適 応があると場合には積極的に肝切除を施行するべきであると考えられた。

PPB-3-135 ICG R15 40\% 超の肝細胞癌症例の検討

関屋 完, 篠原立大, 内野広文, 河野文彰, 児玉英之, 中村邦英, 松崎泰愙, 鬼塚敏男

(宮崎大学第 2 外科)

【目的】ICG15 分停滞率 (ICG R15) が 40\%を超す原発性肝癌症例の治療成績を検討した. 【方

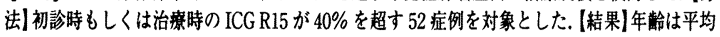
64.5 歳, 男女比は $34: 18$ で, 無治療例が 10 例, 治療例が 42 例で, 治療法は肝切除 6 例, 開 胸もしくは開腹下の RFA・MCTによる烧灼術 11 例, TACE/動注療法 25例であった. 肝切 除例，烧灼例の肝不全による在院死はなかった。肝障害度は B:Cが $24: 28$, 腫場径は $\leqq 2 \mathrm{~cm}$ が 7 例, $>2 \mathrm{~cm}$ が 45 例, 腫場個数は単発が 12 例, 多発が 40 例でであった. 全症例の 1 生率, 3生率は, $59.5 \%, 24.9 \%$ で, 無治療群の1生率, 3生率は, $20 \%, 10 \%$, 治療群の1生率, 3

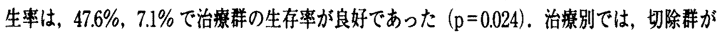
$50.0 \%, 25 \%$ ，烧灼群が $100 \%, 80 \%, \mathrm{TACE} /$ 動注㫱法が $47.1 \%, 14.1 \%$ であった( $=0.0038)$. 単変量解析では焼灼術, 腫瑏径, 肝障害度に有意差を認め, 多変量解析では娆灼術, 肝障害度 に有意差がみられた. [結語]ICG R15 40\% 超の肝練胞癌症例においては,できるだけ早期に診 断し小さなうちに烧灼術を行うことで予後を改善しうると考えられた。

PPB-3-136 高度障害肝合併肝癌に対する大量肝切除適応の GSA シ ンチによる再評価

渡辺直樹, 八木孝仁, 貞森 裕, 松川啓義, 篠浦 先, 尾山孝德, 国富 彩

(岡山大学大学院消化器 - 腫腸外科学)

目的】われわれは GSA シンチによる機能的切除率, 残肝の KL 值を基に, 重度障害胓肝癌 4 症伆に 大量拆切除を施行し得た. (対照】1998.11より2002.10の期間に，外科的治療を施行した KICG 值 0.11 以下の障害肝合併肝第は 44 例であり，そのうち右葉切除以上の肝切除を施行した 4 症例を対象とし

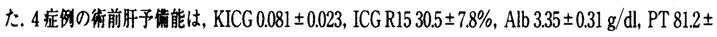

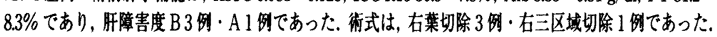

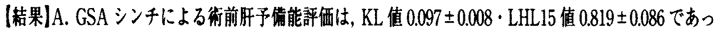
た. B. GSAシンチによる縟能的切除率は，血管浸㳥のためにCT volumetryによる容皘的切除事に比

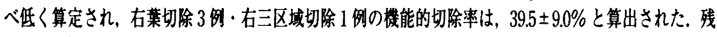

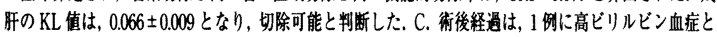

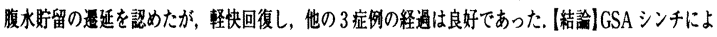

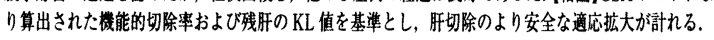


PPB-3-137 大量肝切除術例における 99mTc-GSA シンチグラフィー を用いた周術期の肝機能評価

石津寛之, 近藤征文, 岡田邦明, 益子博幸, 秦 庸壮, 川村秀樹,

植村一仁, 菊池一公, 横田良一

(厚生連札幌厚生病院外科)

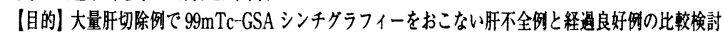

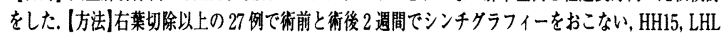

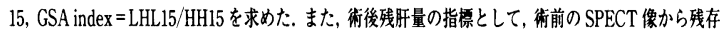

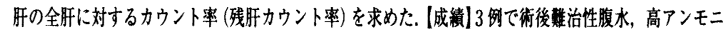

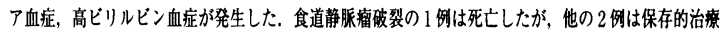

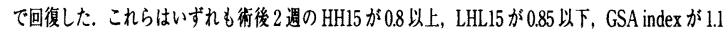

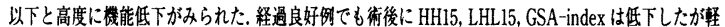
度であった。 各症例の術前, 郝後のHH15, LHL15, GSA-index は良好な相関をみたが, 残肝カウント

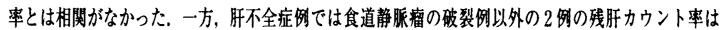

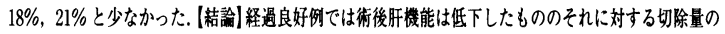

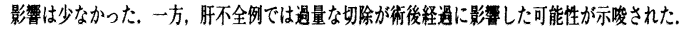

PPB-3-138 拡大肝切後, 過㮃門脈血流の残肝に与える影響について の検証

王 宏昇"，大河内信弘"，榎本好恭"，臼田昌広"，宮城重人"，

舛岡裕雄", 福島啓介", 成田知宏" , 塚本茂樹 ${ }^{\prime \prime}$, 里見 進"

(東北大学大学院先進外科学 ${ }^{11}$, 筑波大学消化器外科 ${ }^{21}$ )

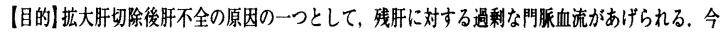

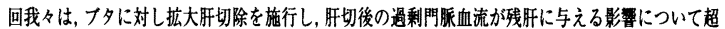

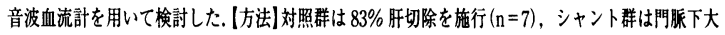
静腺シャントを作成した後に $83 \%$ 肝切除を施行 $(\mathrm{n}=6)$ ，赫中の門胍圧，門脈血流の変化，術後の 生存期間, 形態学的変化を比較検討した. [結果対照群は術後肝不全にて全例三日以内に死亡した が、シヤント群は全例四日以上生存した，肝切除後の門窥圧は対照群で有意に高加た( $\mathrm{P}<0.01)$. $100 \mathrm{~g}$ 肝重量当たり門脈血流量は, 对照群では術後門暞血流量は術前の8倍にまで上昇したが $\mathrm{P}<$ $0.01)$, シャント群では術後門脈血流量が術前の 3 倍程度であり，術後の門㟲血流量は対照群がシャ ント群に対して有意に多いことが解った $(\mathrm{P}<0.05)$. 閉腹時の組織学的所見では, 対照群で門㟲域

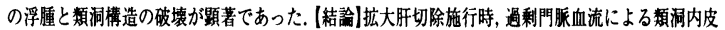
紐胞障害及びそれによる微小循梈障害は肝不全の発生に深く関与していることが示唆された。

PPB-3-139 術後肝不全の病態-容量過小肝における細胞增殖と肝特 異的機能発現-

蒲原行雄, 伊藤雄一郎, 堤 竜二, 川下雄丈, 古井純一郎, 兼松隆之 (長崎大学大学院移植・消化器外科)

目的) 術後肝不全の病態解明のため致死的 $90 \%$ 肝切除モデル(90\%群) を用いて検討. 方法) 释時的に血中炎症性+イトカイン, 增殖因子を测定と残存肝機能, 緗胞增殖関連因子, 肝特異 的機能関連因子, DNA 合成を检討。対照は $70 \%$ 肝切除 (70\% 群)。また本モデルの血㢡を培 養肝紐胞に接触させアルフミン mRNA と DNA 合成についても検索。粘果) $90 \%$ 群では血液 の炎症性サイトカイン, 增殖因子は直後加急增し高值が管延 $(\mathrm{P} \leqq 0.01)$. 練胞增殖は $90 \%$ 群 でStat3が早期に活性化されたが，肝不全導入 12 時間後にはStat inhibitorにより不活化され DNA 合成には至らず, 同時に肝特異的機能関連因子群は発現が減弱. 導入 18 時間後の肝不全

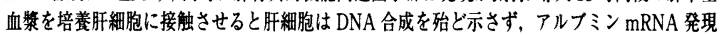

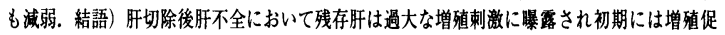
進・分化抑制体制をとるが，負の feedbackにより增殖通程も最終的にDNA 合成を抑制され

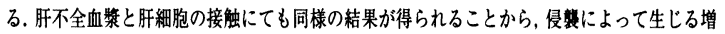
殖系シグナルの制御が術後肝不全の回避・治療に重要であることが示唆された。

PPB-3-140 右肝動脈塞栓先行門脈塞栓術後に肝右葉切除術をおこ なった肝細胞痁の 2 例

柴崎信一, 山口広之, 七島篤志, 井手 昇, 辻孝, 田中賢治,

澤井照光, 安武 亨, 中越 享, 永安 武

(長崎大学大学院腫瘍外科)

(症例 1) 41 歳, 女性. B 型肝硬変合併例で, ICGR15 が $23.5 \%$. 肝切除率が $59.4 \%$ で, PVE を実施. PVE 後の切除索は $57.1 \%$ と効果不十分で, さらに TAE 併用 PVEを実施. TAE 先行 PVE2 週後の切除率は $50.5 \%$ と低下し, ICGR15は 20.0\%であった. 肝アシアロシン 千による機能的肝容皘の右葉：左葉は $0.48 ： 0.52$ から $0.39: 0.61$ へと左葉での增加がみら れ, PVE22 日後に肝右葉切除を実施. 重篤な合併症を生じることなく順謂に経過した（症 例 2] 55 歳, 男性. B 型慢性肝炎例で, ICGR 15 が $9.8 \%$, 肝切除率が $77 \%$ で, TAE 先行 PVEを実施. TAE17日後にPVEを実施. PVE2 莮後に肝切除率は $69.7 \%$ と低下. ICGR 15 は $7.7 \%$ であった。肝アシアロシンチによる機能的肝容積の右葉：左葉は $0.77: 0.23$ か ら $0.63: 0.37$ へと左葉での增加がみられ, PVE19 日後に肝右葉切除を実施. 術後合併症な く順調に経過した。〔まとめ〕慢性肝障害を有する症例においても, より高度の塞栓効果が 必要であれば右肝動脈塞栓術を併用することで, 門脈塞栓術の効果增强が期待できる。
PPB-3-141 肝障害時の骨噵細胞の肝細胞への分化のメカニズムにつ いての検討

三木健司"，山崎慎太郎"”，佐田政孝" ，緑川泰"，油谷浩幸”，

高山忠利"，幕内雅敏"

(東京大学肝・胆 - 滕外科"), 日本大学第 3 外科 ${ }^{21}$, 東京大学循環器内科 ${ }^{31}$, 東京大学先端科学技術研究センターダノムサイエンス部")

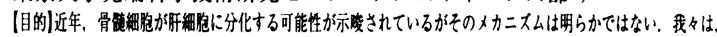

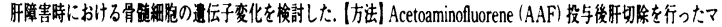

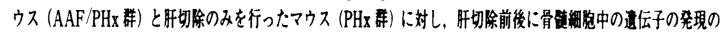

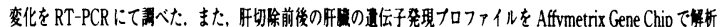

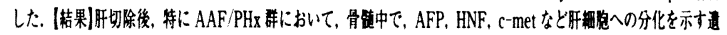

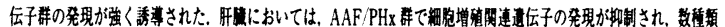

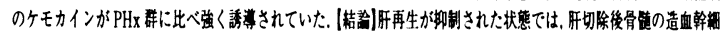

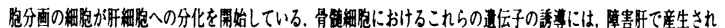

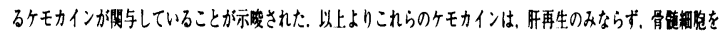

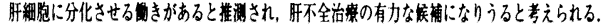

PPB-3-142急性肝不全に対する GCSF または骨㖪紐胞を用いた肝再 生療法の検討

木全秀人，角尾英男，林 㖨治

(国立東名古屋病院外科)

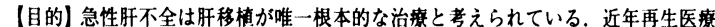
研究が進歩し肝細胞を用いた人工看腈や肝細胞移植が注目されている.また骨跹は 各種幹紐胞を豊富に含み再生医療で注目されている. 今回我々は急性肝不全に対す

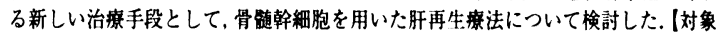
と方法IWister 婎性ラットを用い萝剂肝障害モデルを作成，1)GCSF 投与，2）HGF 遺伝子導入骨㩆絊胞投与の 2 群で, GOT, GPT, LDH, necrosis index (NI)，apop-

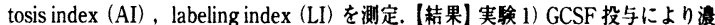
度依存性に, 白血球数は增加し，GOT，GPT，LDHの上昇は抑制された，对照群で NI， AI は有意に高く，LI は有意に低かった，実験 2) HGF 産生量は，MOI 依存性 に上昇し，HGF 道伝子導入骨㖪緗胞投与により GOT, GPT, LDH 上昇は抑制され た。対照群でNI, AI は有意に高く，LIは有意に低加た。結論】急性肝不全に対 する GCSF または HGF 运伝子導入骨蹎稩胞を用いた肝再生療法は有効である。

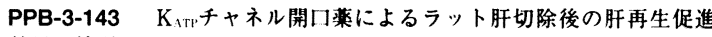
効果の検討

山崎圭一, 竹村茂一, 裴 正寞, 高台真太郎, 広橋一裕, 久保正二, 田中 宏, 首藤太一，南山幸子，末広茂文

(大阪市立大学肝胆膡外科)

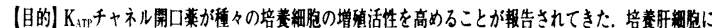

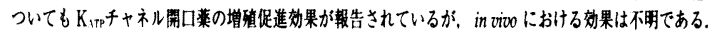
ラット胿部分切除モデルを用いK K

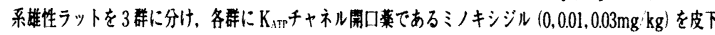

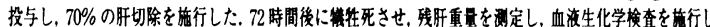

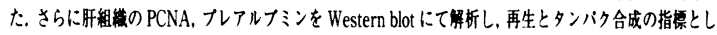

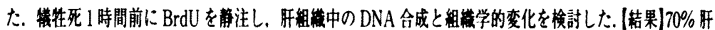

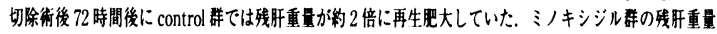

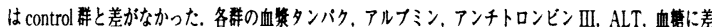

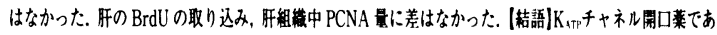

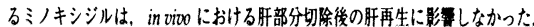

PPB-3-144 M-CSF 欠損マウスにおける肝切除後肝再生荤延と $\mathrm{rM}$ $\mathrm{CSF}$ 投与効果に関する検討

雨宮秀武, 河野 宽, 浅川真巳, 牧 章, 平井 優, 土屋雅人, 松田政徳, 藤井秀樹

(山梨大学第 1 外科)

【目的】肝再生の priming において, TNF- $\alpha$ とIL-6は重要な役割を果たし，産生源と してKupffer 細胞 $(\mathrm{KC})$ が考えられる．KCが約 30\%に娍少し未热である M-CSF 欠䭫 マウス (op) を用い, 肝切除後肝再生について検討. (方法) 正常マウス (C；C57BL) と op より KC を単離後エンドトキシンで刺激し, TNF- $\alpha$, IL- 6 mRNA 発现を検討. $50 \%$

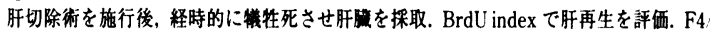
80 と CD68 の免疫組織染色を施行. TNF- $\alpha$, IL -6 mRNA 発現を梌討. 肝切除 2 日前.

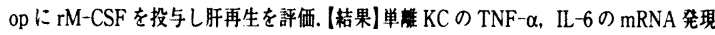
は同程度. Op において BrdU index は沏切除 2 日後の peak が消失, F4/80, CD68 陽性 細胞はCの約 $30 \%, \mathrm{TNF}-\alpha$, IL-6の mRNA 発現は減弱, 荤延. BrdU index は rM-CSF 投与によりCの $80 \%$ まで回復. [榬論】未热 KC 存在下の肝切除後肝再生は荤延してお $ク, \mathrm{TNF}-\alpha$ 依存性に誘導された。 $\mathrm{rM}$-CSFの投与により，肝再生荤延か回復した。 
PPB-3-145 ラット肝類洞再構築における mTOR およびMIF の発現 に関する実験的検討

前野 博, 比良英司, 小野隆司，山野井彰，山[1峰一，永井聡， 小野田敏尚, 山本佳生, 山本 徽, 永末直文

(島根大学第 2 外科)

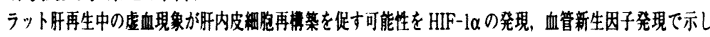

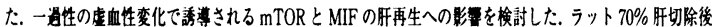

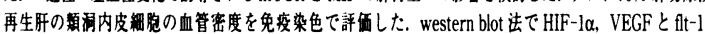
mTOR, MIF を HIF-l $\alpha$, VEGF と At-1をRT-PCR 法にて䛨值した，肝緗胞及び内皮緗胞の增殖は各々訮

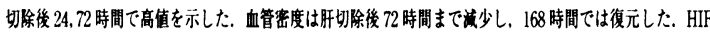

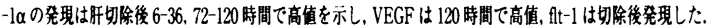
$\mathrm{mRNA}$ は HIF-l $\alpha$ は 24, 72 時間, VEGF は 48,72 時間, flt-1は 48,96時間て增加した. mTOR は肝切除後

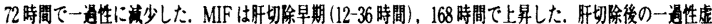

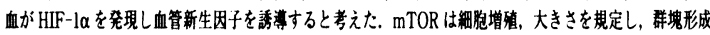

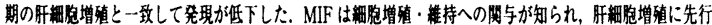

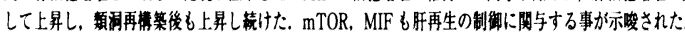

PPB-3-146門腺枝塞栓術後の非寨栓葉再生に関する基整的実倹 笹本彰紀，二村雄次，柳野正人，晹浅典博，小田高司，新井利幸， 西尾秀樹, 江烟智希

(名古屋大学大学院器官調節外科)

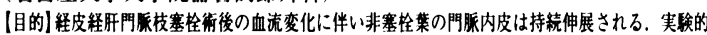
に内皮稩胞に持蒜伸展を加え NF- $\mathrm{kB}$ を介し肝再生の triggerであるIL-6が分泌された．今回は

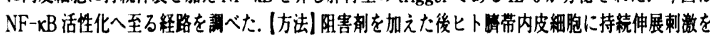

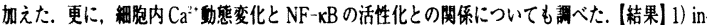
tegrin 阻害ベフチド (GRGDNP)，PLC 阻害郕 (U73122)，PKC 阻害郕 (H7) でNF-KB の话性は 阻害きれた，2）thapsigargin（TG）・EGTAで細胞内・外 $\mathrm{Ca}^{2+}$ を枯渴させた状態では NF- $\mathrm{xB}$

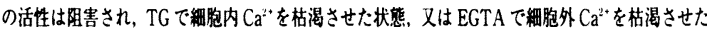
状態では阻害されなかった. 3)PKCの活性は GRGDNP, U73122の投与、TG・EGTAで細胞内・

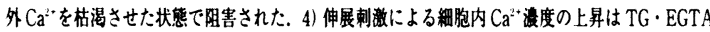
で緗胞内・外 Ca”を枯渴させた状憼では認めず，TGで細胞内 Ca”を枯渴させた状態，又は EGTA

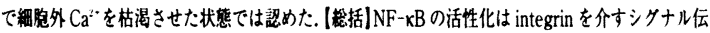
䞗にはじまるCa”依存性 PLC/PKC 経路は重要な役割を果たしていることが示唆された。

PPB-3-147 ラット肝不全モデルに対するヒト肝芽腫細胞株を用いた 細胞㞠法に関する研究

播本憲史，島田光生，北川 大，伊藤心二，辻田英司，前原伸一郎， 武畐紹信, 由中真二, 調

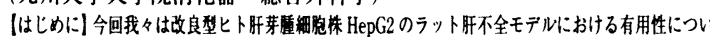

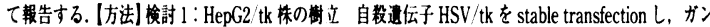

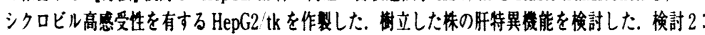

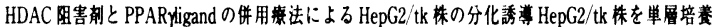

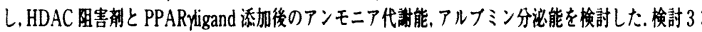

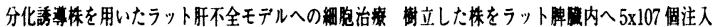

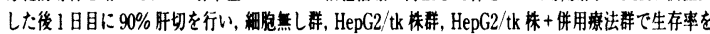

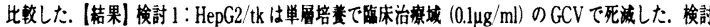

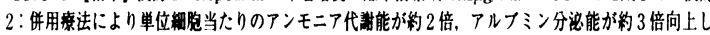

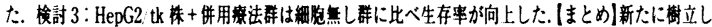

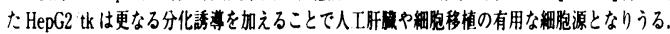

PPB-3-148 マウス ES 細胞由来肝細胞の浱縮と奇形腫発生の子防

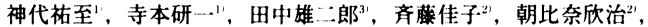
寺岡弘文", 有井滋樹

(東京医科歯科大学肝胆䐙外科"，東京医科菊科大学難治研病態生化学 ${ }^{2}$, 東京医科菌科大学附属病院総合診療部 ${ }^{31}$ )

ES 細胞から肝細胞を分化誘墓できれば，細胞移植医寮の細胞源として有望である，我々はマ ウス $\mathrm{ES}$ 細胞由来胚粎体 (EB) 中での機能的な肝実質細胞への分化誘導と，9 日目 $\mathrm{EB}$ から単

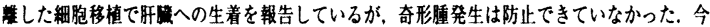
回我々は EBから肝細胞を瀑樎すると同時に，奇形腫の原因となる未分化な細胞を取り除く ことが可能か㛟討した，EBを単層培養とした後，Percollにより細胞を分画し，それぞれの 分画でアルフミン, Oct3/4の mRNAの発現を検討した、アルフミン淂性かつ Oct $3 / 4$ 陰性分

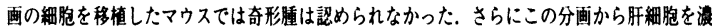

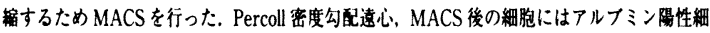
胞が約 30\% 含まれており，尿素合成能も有していることを確認した。これらの結果より機能 的な肝稩胞の瀑制と奇形腫の形成を防止することができたと考えられた．現在，肝障害マウ スにこの絧胞を移植し、肝機能か改善するかどうかについても検討中である.
PPB-3-149 免疫隔離膜内肝細胞の長期凍結保存方法の確立とその応 用

青木武士，古泉友丈，安田大輔，泉田欣彦，金 正鎬，華 魯純， 村井紀元, 清水喜德, 加藤博久, 草野満夫 (昭和大学一般消化器外科)

(目的) 今回免疫隔噰膜内肝緗胞の長期凍結保存方法の確立およびそれらを用いた新たな人工胿腊 モジュールとしての可能性を報告する. (方法)ラット肝細胞をマイクロカプセル化し，直ちに液体 窒素にて凍結保存した（実験 1) 120 日間凍秸したカプセルを経時的に解凍し，組繶学的評価，薬 物代謝能を検討. (実験 2)1週間凍結カブセルを 2 週間培養. 肝特異的代謝能, 組織学的にその機 能を評価. (実験 3) ヒト肝細胞をマイクロカブセル化し同様な方法にて90日間凍結保存し，経時 的に解涷後組織学的評価. (実験 4)ラジアルフローパイオリアクターへ凍結保存免疫隔離膜内肝細 胞を loading し, 肝特異的代謝能, 組織学的検討. (結果) (実験 1)カプセル内ラット肝細胞は viabil ity を維持し ALB，PASに陽性発現し，OAT2,CYPの発現を認め，(実験 2) 培養後もその肝特殊 代誹機能を維持し (実験 3 ) 少なくとも 90 日間 viableであり, ALBの発現を維持. (実駼 5) 少な くとも24 時間肝特異的代詩能を維持した. (考察) 免疫隔離膜内ラットおよびヒト肝細胞をその機 能を失わず長期凍結可能であり，また体外肝補助システムとして機能しうることが示唆された

PPB-3-150 肝細胞癌に対する肝切除後 10 年以上の長期生存例の検 討

片寄 友, 海野倫明, 力山敏樹, 及川昌也, 山本久仁治, 小野川徹, 阿部友哉, 大塩 博, 较内伸一, 松野正紀

(東北大学大学院消化器外科学)

(目的】肝細胞症切除例において 10 年以上の長期生存を得るための条件, 治源法を検討すること とした. [症例] 症例は 1973 年から 2001 年 12 月までの最短 3 年以上の経過観察をした肝切除例 176 例を用いた，そのうち 5 年以上生存例が 36 例あり，そのうち 5 年から 10 年で死亡した 11 症 例を A 群, 10 年以上生存した 14 例を B 群として検討した. (結果]ウイルスマーカーは, 差は談 められなかった，肝機能に関しては全例 Child-Pough 分類で A. またICG，血小板，Alb，総ビリ ルビン, PTに差はなく，腫激因子にも差はなかった. 術式は A 群部分切除 7 例, 区域切除 4 例, $B$ 群は部分切除 5 例, 区域切除 1 例，葉切除以上 8 例であった。無再発生存期間は $A$ 群が 3.5 年で あるのに対して, B 群は 12 年で, 10 年以上の長期生存例は無再発例が多いことがわかる.つまり， 再発後の治療で長期生存を得ているのでは無く，初回切除の治療方針および手術時の状況に予後 が既定されているとも考えられる.|まとめりこれまでの既存の治療では良い結果が得られないと 考えられ，今後肝移植など新规治㞠の工夫により長期生存を図る必要があると考える.

PPB-3-151 肝切除後 10 年以上経過した肝細胞癌症例の検討 坂東 正", 渋谷和人 ${ }^{11}$, 野澤聡志 ${ }^{11}$, 塚田一博", 霜田光義1.21 (富山医科薬科大学第 2 外科"，氷見市民病院外科 ${ }^{21}$ )

【目的】切除可能例における肝細胞癌外科治療後成績は他の治療を淩駕しているが，5 年生存が得られても異時性多発病変や併存肝病変の悪化がみられる場合もあり検討が必 要である. [方法] 肝切除後 10 年以上経過した 38 症例に関して検討した. [成續] 男性 31 例女性 7 例で平均年龄は 58 才であった。死亡は 29 例で, 原病死が 14 例で肝不全死は 7 例であった。累積生存率は 5 年 $43.4 \%, 10$ 年 $26.1 \%$ であった。累積非再発率は 5 年 $22.4 \%, 10$ 年 $11.2 \%$ であった. 術後 5 年以上の生存が得られたのは 15 例 $39.4 \%$ で, 8 例が生存中で, 無再発生存は僅か 3 例であった. 15 例中 12 例は, 平均 48 力月で再発し ており， 5 年経過後の再発は 3 例に認められた。再発時からの平均生存期間は 72 力月で, 再発までの期間より長く最長 14 年であった。再発 12 例はいずれも肝内再発で，単発が 8 例で内 4 例には再切除を施行し, その他の症例に対しては chemolipiodolization を中心 とした内科的な治療を施行した. chemolipiodolization を予防的に施行した症例で予後の 延長が認められた。結詥] 肝細胞癌の長期予後は再発後の再切除も含めた治療による生 存期間の延長が重要であり，予防的 chemolipiodolizationも有用な方法と考えられた。

PPB-3-152 当科における肝癌治療後 10 年以上生存例の検討 斉藤环已, 石崎 彰, 大沼 淳, 吉川大太郎, 山崎弘貴, 唐崎秀則, 稲垣光裕, 小原充裕, 紀野修一, 葛西真一

(旭川医科大学第 2 外科)

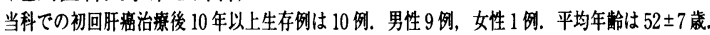
肝炎ウイルスマーカーは HBV 陽性が5例，HCV 淂性が5例，背景肝は胿硬変 5 例，慢性肝炎 3 例，正常肝 2 例. 初回治療に手術を選択した例が 9 例, 1 例は Vp3 症例でリザーバー動注療法を 選択. 術式は左葉切除 2 例, 要区域切除 3 例, 部分切除 4 例. 初回単発例は 7 例, 初回治療時の

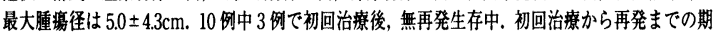
間は 7 桝中 3 例で 8 年以上であり，平均 5.6 年。外科的切除後に再発を認めた 6 例は，再発時に胿

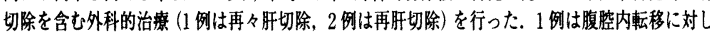
て摘出術を柂行，1例は肺転移に対して肺切除も施行. 4 例ではTAE, PEIT を含む集学的治療を 行った，死亡した 6 例中 4 例力原病死, うち 3 例で門腺腫場栓を伴う diffuse な HCC を発症し死 亡. Vp3 症例はリザーバー動注と TAEを繰り返し施行し, 10 年 10 个月後他病死. 肝病变再発を 認めた場合，積梗的な外科的治療を含む集学的治㫫により予後の延長力゙期待できると思われた。 Vp3 症例でもリザーバー動注を含む治療により長期生存か得られる可能性もあると思われた。 
PPB-3-153 肝細胞癌術後 10 年生存の条件

山田卓也, 関野考史, 松尾 浩, 吉田直優, 宮原利行, 木山茂, 竹村博文

(岐皁大学第 1 外科)

【目的】肝細胞癌衍後 10 年生存の条件を検討した.【対象】1989年から 2003 年までの肝紐 胞癌手術症例 74 例中, 10 年以上生存した 6 例 (A 群) と 10 年末满で肝紐胞棉原病死した 27 例 (D 群)，(方法】10年生存可能な予測因子として, 術前因子, 手術関連因子, 術後関 連因子, 組織学的因子を両群で比較榆討した. 統計学的处理は $\mathrm{t}$ 検定・ $\chi^{2}$ 愉定を用い, 危険 事 $5 \%$ 末満を有意とした. (結果】A 群の平均年柃は $60 \pm 12$ 歳, 男女比は $2: 1$, 肝障害度は 全例 $\mathrm{A}$, 最長生存期間は 177 力月であった。術前因子は, 1) KICG：A 群 $0.148 \pm 0.03 \cdot \mathrm{D}$ 群 $0.109 \pm 0.032(\mathrm{p}=0.021)$, 2) 血小板数: $\mathrm{A}$ 群 $16.7 \pm 2.8 \times 10^{4} \mathrm{~mm}^{3} \cdot \mathrm{D}$ 群 $10.4 \pm 4.5 \times 10^{4}$ $\mathrm{mm}^{3}(\mathrm{p}=0.0027)$ で, 組緎学的因子は 3$) \mathrm{St} / \mathrm{Mt}: \mathrm{A}$ 群 $6 / 0 \cdot \mathrm{D}$ 群 $\left.13 / 14(\mathrm{p}=0.027), 4\right) \mathrm{Fc}+$ $\mathrm{Fc}-: \mathrm{A}$ 群 $1 / 5 \cdot \mathrm{D}$ 群 $16 / 5(\mathrm{p}=0.0152), 5) \mathrm{Sf}+/ \mathrm{Sf}-: \mathrm{A}$ 群 $1 / 5 \cdot \mathrm{D}$ 群 $18 / 3(\mathrm{p}=0.0037)$, 6) $\mathrm{LC}+/ \mathrm{LC}-: \mathrm{A}$ 群 $2 / 4 \cdot \mathrm{D}$ 群 $20 / 2(\mathrm{p}=0.0096)$ であった. 手術閶連因子, 術後関連因子 では有意差を認めなかった。 [結詥] 肝細胞癌術後 10 年生存の必要条件は 1) St+, 十分条 件は2）血小板数正常，3）K ICG 正常，4） $\mathrm{Fc}^{-}$，5） Sf-，6）LC-であった

PPB-3-154 肝細胞癌治瘾切除例における再発後 5 年以上生存例の検 討

川端良平，佐々木洋，山田晃正，江口英利，宮代 熟，村田幸平， 土岐祐一郎，大東弘明，石川 治，今岡真義

(大阪府立成人病センター外科)

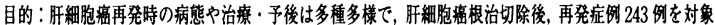

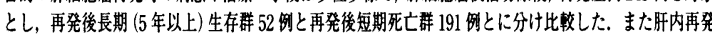

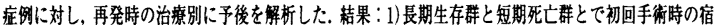

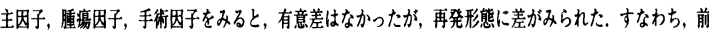

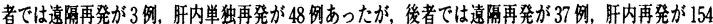

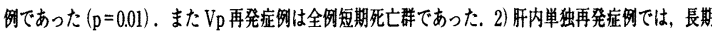

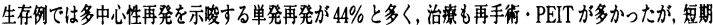

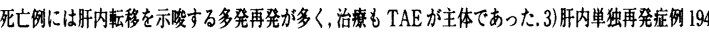

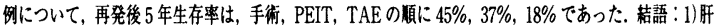

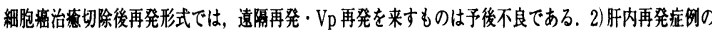

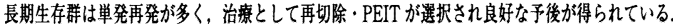

PPB-3-155 肝細胞癌の術後 5生以降の予後因子について 呉 成浩, 金子哲也, 竹田 伸, 井上総一郎, 中尾昭公 (名古屋大学大学院病態制御外科)

緒言肝細胞癌の長期生存に寄与するものは外科切除である. 初回手術後 5 年以上生存し た患者のなかで，さらにその後の予後に影算を与える因子についての報告は少ない. 方 法 1986 年から 1998 年の期間に肝絊胞㾇で初回手術後 5 年以上生存した患者を対象と L，年龄性別，血清 T-Bil 值，ICG-K 值，原因肝炎ウイルス，Alb，PT，AFP，Child 分類, CLIP score, 術後 T-Bil 最高值, 術式, など, 初回手術時の踟床的因子を整理し、 5 生以後の予後因子を比較検討した. 結果肝切除を施行した 445 人中 5 年以上生存者は 116 人. 初回手術時背景 : 平均年齢 $58 \pm 9.1$ 歳, 男 : 女 $=94: 22$, T-Bil 值 $0.76 \pm 0.29 \mathrm{mg}$ $\mathrm{dL}$, 出血量 $1538 \pm 1748 \mathrm{~mL}$, Alb 值 $3.8 \pm 0.35 \mathrm{~g} / \mathrm{dL}, A F P 1350 \pm 5794 \mathrm{ng} / \mathrm{mL}$, Child 分類 全て A, CLIP score ; $0: 71$ 例, $1: 40$ 例, $2: 4$ 例, $3: 5$ 例, 術後 T-Bil 最高值 $2.7 \pm 1.7$ $\mathrm{mg} / \mathrm{dL}$, 術式 $\mathrm{Hr} 0: 49$ 例, $\mathrm{HrS}: 5$ 例, $\mathrm{Hr} 1: 27$ 例, $\mathrm{Hr} 2: 35$ 例. このうち, 5 年以降の 生存に寄与する予後因子はCLIP score 0 ( 0 vs $1,2,3: P=0.027$ ), Tumor Morphology

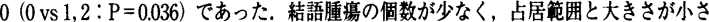
いこと，CLIP scoreが0であることが 5 年生存以降の予後に良好な影稫を与える.

PPB-3-156 肝細胞癌術後長期生存例と 5 年以内死亡例の比較検討 近藤千博, 千々岩一男, 牧野一郎, 甲斐真弘, 江藤忠明,

大内田次郎, 長沼誠二

(宮崎大学第 1 外科)

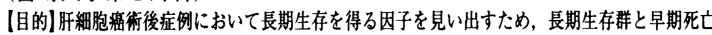
群につき，種々の因子を比較した（方法】当科で1990から2003年までに切除術を受けた訮緗胞 癌症例のうち，術後 8 年以上生存例 (A 群, 22 例) と術後 5 年以内死亡例 (B 群, 98 例) を比 较した。比較項目は，年令，性別，腯場因子，背景䏕因子，手術因子としたささらに，8年以上

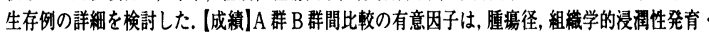

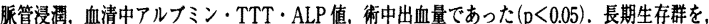
1 群: 術後無再発群 $(8$ 例)，2群：術後 5 年以内再発群 $(7$ 例)，3 群：術後 5 年以上経通後再発 群（7例）に分けた， $2+3$ 群の主な再治療は，TACE，再手術であった. 1 群と $2+3$ 群との比 較で，性別，TTT・ZTT 值，C型肝炎陽性率に差があった（結諳]術後長期生存を得るために

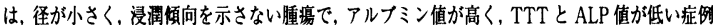
に，出血の少ない手術を行う必要がある。再発例には，TACEや再手術を行う。また，術後長 期生存例のうち，長期無再発は，C型肝炎陰性て腾質反応低值の例に得られやすい。

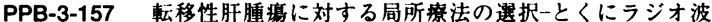
焼灼療法の有用性と課題

上野桂一，長谷川泰介，原田英也，吉谷新一郎，中野泰治， 北林一男, 斎藤人志, 小圾健夫, 喜多一郎, 高島茂樹 (金沢医科大学一般消化器外科)

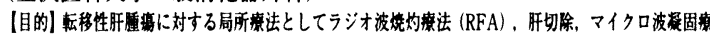

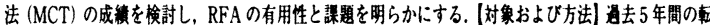

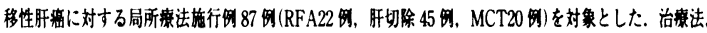

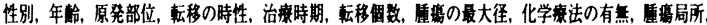

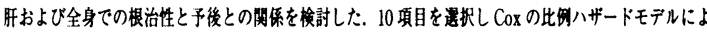

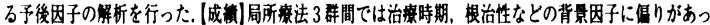

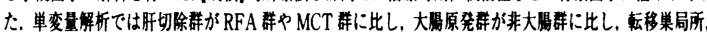

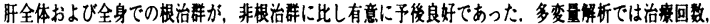

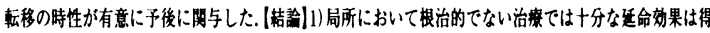

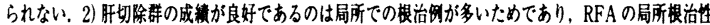

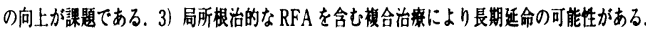

PPB-3-158 転移性肝㿋に対するラジオ波嬅却亦法の試み 高椅 誠"，柴野成幸"，長 晴彦"，大矢 清"，町 淳二" (上白根病院外科 ${ }^{2}$, ハワイ大学外科 ${ }^{2}$ )

檕移性肝癌に対するRFAについて検討したので報告する.「症则」1999 年 4 月から 2003

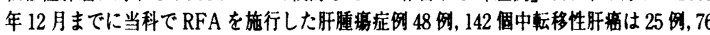

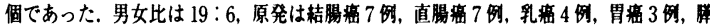

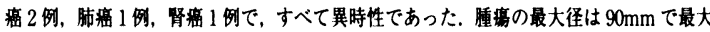
個数は 11 個で, RFA 最高施行回数は 4 回で平均 1.4 回であった。また全例肝硕変の合併 はなかった「海㐫およひ方法」1999 年は $3 \mathrm{~cm}$ 以下，3 個以下の症例に限定していたが， 2000 年より $3 \mathrm{~cm}$ 以上の症例は全麻下，ししくは硬麻下にて周井に約 $5 \mathrm{~mm} \sim 1 \mathrm{~cm}$ の mar

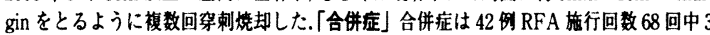
例 $4.4 \%$ で, 胆管炎 2 例, 肝不全 1 例であった，うち胆管炎 1 例は術後 11 病日に死亡し た.肝不全症例は術後 29 病日に死亡した. 街後出血は 1 例も見られていない.「再器事」姑 息的なものを除いた再発事は 13 例中 4 例 $(30.7 \%)$ であったが局所再発例は 1 格 $(7.7 \%)$

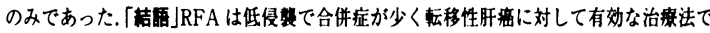
あるが，再発率をさげるために動注港法等の併用が必要と考えられた。

PPB-3-159 消化器癞の肝転移に対するラジオ波娔办術の成績 前川 博, 仙石博信, 大内一智, 佐藤浩一, 前川武男 (順天堂大学伊豆長岡病院外科)

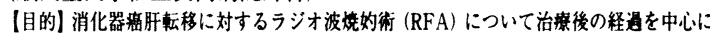
検討し，RFAの問题点を検討した（方法】対象は当科で通去 3 年間にRFAを受けた消化

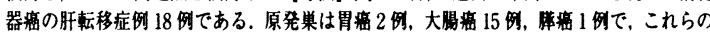

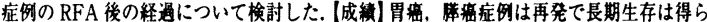

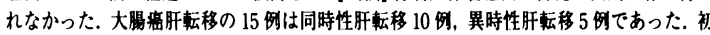

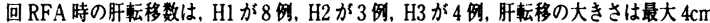

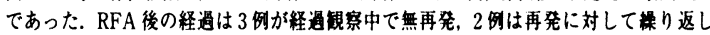

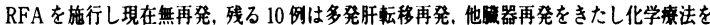

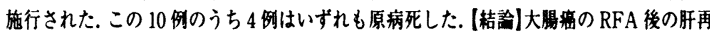
発は転移紧が $3 \mathrm{~cm}$ を越えると肝転移再発のリスクが高くなる。繰り返しRFAを范行す ることは可能であるが，十分な ablationの笝用をとった烧妁手技が必要であると考えら れた．また H3 症例に対しては RFA 後の再発の可能性が高く, RFA 単䖵の治瘄効果は少

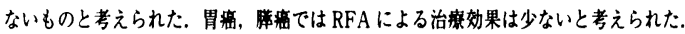

PPB-3-160 転移性肝㾞集学的治㞠におけるマイクロ波凝固療法の役 割

大田耕司"，川㴊義治"，吉田和弘"，挊 哲哉"，澤村明廣

(広島大学原医研腫瘍外科"，曙会シムラ病院外科"')

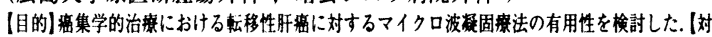

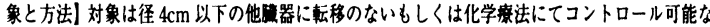

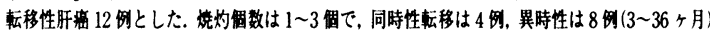

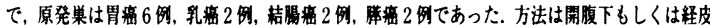
的に゙マイクロターゼを用いて深部電極では出力 $30 \mathrm{~W}$ ，照射時間 90 移にて，針状電梅では $60 \mathrm{~W}$ ，

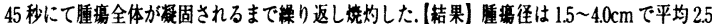

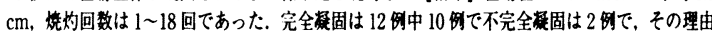

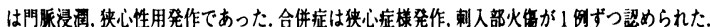

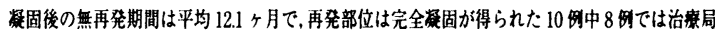

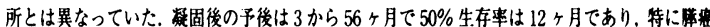

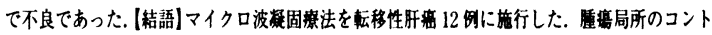
ロールに有用であり，さらに症例を重ね，予後に対する有刘性を検討していきたい。 
PPB-3-161 大腸癌肝転移に対する治療成鎮一予後因子とマイクロ波 凝固㞠法の有用性について一

森田哲史，柴田 高，奥山正樹，池田公正，藤田淳也，苩 和臣， 秦 信輔，塚原康生，北田昌之，島野高志

(市立豊中病院外科)

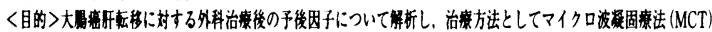

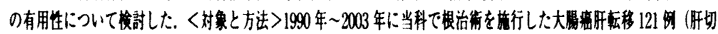

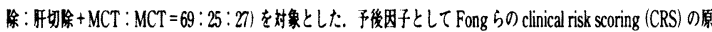

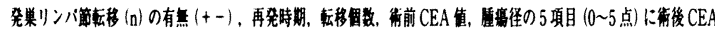

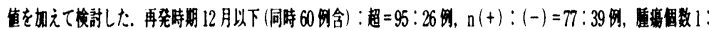

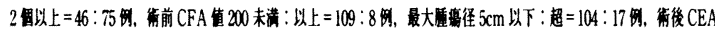

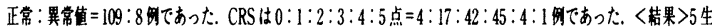

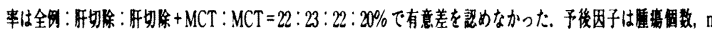

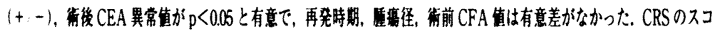

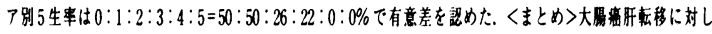

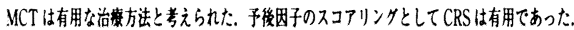

PPB-3-162 肝内胆管瘦治窟切除不能例へのマイクロ波凝固療法 (MCT) の有用性の検討

深濑耕二, 海野倫明, 片寄 友, 力川敏樹, 及川昌也, 山本久仁治, 水間正道

(東北大学大学院消化器外科学)

【背景】肝内胆管癌は手術以外の有効な治撩法は確立されていないが，発症時 には進行しており治喼切除不能な症例は少なくない. 癌化学療法, 放射線療法 等の有効贯は決して高いとはいえないのが現状である. 【対象】過去 13 年間に

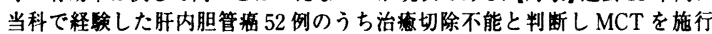
した 5 例. Stage は 3 が 2 例, $4 \mathrm{~b}$ が 3 例.【結果】周術期に大きな合併症は認め なかった. 再発形式は局所再発 1 例, 残肝再発 4 例. 一年生存率 $80 \%, 2$ 年生

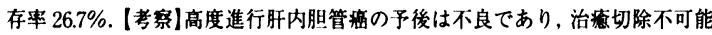
と判断した場合は過大侵繁を避けるべきと考える。当科の治瘾切除群と比較 すると生存事は不良, 非治漟切除群, 非切除群よりは良好であった。本治㙩法

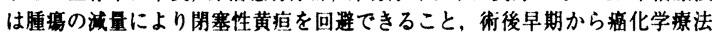
が可能であり，高度進行肝内胆管䠛の姑息的治療として有用と考えられた。

PPB-3-163 肝 S1 に再発した胆管細胞繳に対して開腹下マイクロ波 凝固壊死療法 (MCT) を施行し著効した 1 例

石椅一慶, 緑川武正, 畑山年之, 梅本岳宏, 上道治, 水上博喜,

真田 裕

(昭和大学藤が质院外科)

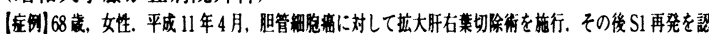

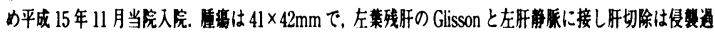

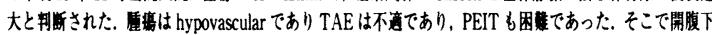

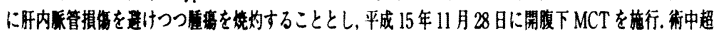

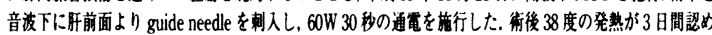

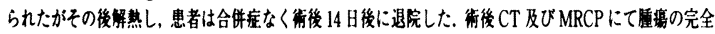

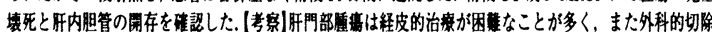

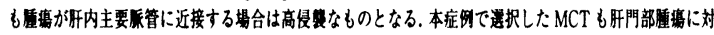

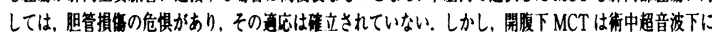

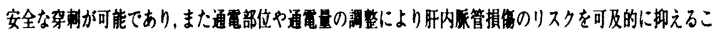

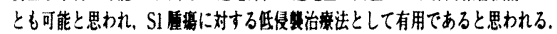

PPB-3-164 大腸税肝転移に対する肝切除施行症例の検討 斎藤克憲, 近藤 哲, 平野聡, 田中栄一, 原敬志, 森川利昭, 奥芝俊一, 加藤紘之

(北海道大学大学院腫堭外科)

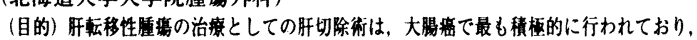

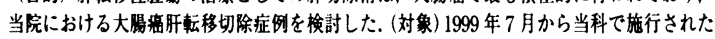

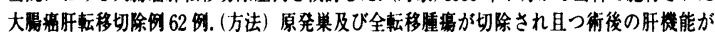

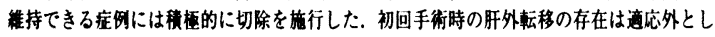

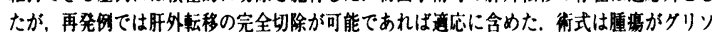

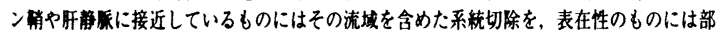

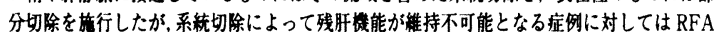

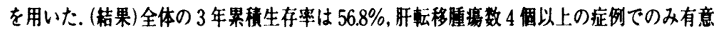
に予後不良であった。また，初问切除例と再切除例では予後に有意差はなかった（桔語)大

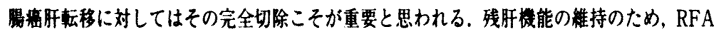
を尊入することにより手術息応の搪大を图っている。また，再肝切除は初回切除の成绩に 劣らないため，手術息底を满たせば初回手術同栚皘板的に施行していくべきと考える。
PPB-3-165 腫瘍径 $3 \mathrm{~cm}$ 以下の大腸癌肝転移症例に対する術式選 択 : 系統切除か, 部分切除か

北見智恵, 黑崎 功, 小川 洋, 横山直行, 二瓶幸栄, 畠山勝義 (新潟大学大学院消化器 - 一般外科)

[目的】本研究では径 $3 \mathrm{~cm} 2$ 個以下の大腸癌肝転移に対してどのような術式が妥当で あるかを再発様式，生存率から検討した. [対象と方法] 对象は腫場径 $3 \mathrm{~cm}$ 以下， 2 個以下の大腸癌肝転移 29 例. その切除術式によって $\mathrm{A}$ 群 $(\mathrm{n}=7): 1$ 区域以上の系統 切除 (単発 4 例, 2 個 3 例), B 群 $(n=22)$ : 要区域以下の切除（単発 18 例, 2 個 4 例)の 2 群に分類した. [結果]1. 両群で同異時, 原発巣の進行度に差を認めなかった。 2. 残肝再発は $\mathrm{A}$ 群 1 例 $(14 \%), \mathrm{B}$ 群 15 例 $(68 \%)$ に認めた $(\mathrm{n}=0.03)$. A 群では対 僋肝再発 1 例であった。一方, B 群では同側肝 6 例, 対側肝 2 例, 両葉再発 5 例であっ たここれらに対し A 群では再肝切除を行ったが, B 群では再肝切除を行い得たのは 8 例 $(53 \%)$ であった. 3.全経過中肝外再発を生じた A 群 1 例，B 群 8 例を除いた 5 生事は A 群 $100 \%(\mathrm{n}=3), \mathrm{B}$ 群 $53 \%(\mathrm{n}=3)$ と有意に A 群で予後良好であった $(\mathrm{p}=$ 0.02). [考察]系統的切除を行った群で残肝再発率が低く, 長期生存が得られる傾向が 認められた．今後多数例での prospectiveな検討をする必要があると思われた。

PPB-3-166 大腸癌肝転移に対する肝切除術の評価一系統的肝切除の 意義について

山本久仁治", 海野倫明", 片寄 友"，力山敏樹"，及川昌也", 井伊貴幸"，竹内丙午 ${ }^{21}$ ，松野正紀"

(東北大学大学院消化器外科学 ${ }^{11}$, 十和田市立中央病院外科 ${ }^{21}$ )

【目的】大腸癌の肝転移に対する肝切除の意義は広く認められているが残肝再発率を下 げることは更なる予後の改善のために重要な課題の一つである。 そこで我々は 1982 年 から 2002 年の 21 年間に大腸癌肝転移巣に対し肝切除術を施行した 67 例を対象に統計 的な比较検討を行い初回術式選択について検討した. [結果】 症例は H1 単発 47 例, H1 多発 7 例, $\mathrm{H} 2$ が 11 例, $\mathrm{H} 3$ が 2 例であり，区域切除以上の系統的切除が 48 例, 部分切 除が 19 例に施行された。全切除例の 5 年・10 年生存率は各々 $39.8 \% \cdot 32.4 \%$ であっ た. $\mathrm{H} 1$ 単発例の 5 生率は $43.6 \%$ と他の群と比較し良好な成績であったが, 最大腫黈径

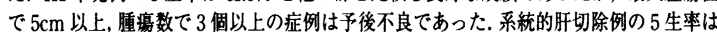
$44.4 \%$ であり, 部分切除の $29.6 \%$ より予後良好であった. [結語]以上より系統的肝切除 は特に $\mathrm{Hl}$ 症例の初回肝切除術として推奖できる。一方, 多発や巨大腫場では肝切除単 独では予後の改善は困難であり, 術前補助化学療法を考慮すべきである.

PPB-3-167 大腸癌多発 (4 個以上) 肝転移の積極的切除 東 久登, 志田晴彦, 坂佳奈子, 山形諴一, 増田幸蔵, 今成朋洋, 山本登司

(東京厚生年金病院外科)

【目的】大腸癌多発 (4 個以上) 肝転移の治療方針につき考察する 【方法】当院での大 晹富肝転移の手術方針は, 1. まず切除. 転移菓が多ければ術後に肝動注化療を行う.2. 残肝機能に余裕がなければ肝動注化暴 一奏功したら肝切除. 3. 拡大莱切除が必要で, 残 肝機能に余裕がなければ肝動注化療+門脈塞栓 $\rightarrow$ 肝切除. 4. 肝切除後は化学療法を行 j. 5. 残肝再発や肺再発時は可能な限り再切除. 以上である. 対象は当院での大腸癌肝 転移治瘾切除 108 例中, 多発 (4 個以上) 症例 27 例. (結果) 転移個数は平均 7.0 個 (4 19 個). 術式は門脈塞栓十肝動注化㞠 $\rightarrow$ 肝切除 3 例, 肝動注化療 $\rightarrow$ 肝部分切除 1 例, 拡 大左葉切除 2 例，右葉切除 2 例，区域切除 3 例，部分切除 16 例であった. 24 例には術 後化竟 (20 例は肝動注化撩) を施行した. 5 年累皘生存率は $34.5 \%, 5$ 年累皘無再発生 存率は $5.0 \%$ であった. [結論]一般的に多発肝転移は予後不良で生存率は低いとされ ているが, 当院では 4 個以上の大腸癌多発肝転移に対しても積極的に治療を行い, 非常 に良好な結果を得た。多発肝転移に対する積梗的切除は妥当な方針と考える。

PPB-3-168 転移性肝癖に対する手術的治療

三島秀樹, 田中荘一, 梅北信孝, 大久保貴生, 井上 暁, 北村正次 (東京都立墨東病院外科)

目的)大晹癌肝転移に対する治㙩として外科的切除が標準だが，胃癌に関しては議 論がある.肝転移の治療戦略につき臨床的に検討する.対象) 1989 年から当科で切 除した大腸稳肝転移症例は 167 例であり, 211 回の切除を施行した. 44 例に残肝再 発再切除を, うち 10 例に 3 回以上の切除術を施行. 胃癌肝切除は 24 例 (26 回) に 施行した．結果）大晹癌は転移個数 1-30 個（平均 3.0 個）であった，累皘 1,3,5 年生存率は単数 $89,69,50 \% .2-3$ 個 $87,47,26 \% 4$ 個以上 $76,38,10 \%$ で多数個の例 でも長期生存があった. 予後规定因子はりンバ節転移・転移個数などであった. 肝 動注例の子後は非動注群と比較して良好であった。予後因子の高スコア例では肝 動注を施行しても多数の症例で肝再発を認めた。胃癌肝転移は 3 年以上無再発生 存中が 5 人あり, 累積 5 年生存率は $29 \%$ であった. 同時性, 多発例にも長期生存 があった. 化学療法が有効で肝が CR となり原発巣が摘除された症例もあった.ま とめ)大腸癌は積極的な切除と切除後の動注化学療法が望ましい. 胃癌肝転移は切 除と全身化学慮法を組み合わせることにより, 予後の改善が望める. 
PPB-3-169 大腸癌肝転移に対する, 下大静脈・肝静脈合併切除再建 を伴う肝切除の短期・長期成績

青木 环, 橋本拓哉, 今村 宏, 長谷川潔, 佐野圭二, 菅原蜜彦,

國土典宏, 幕内雅敏

(東京大学肝 - 胆 - 膡外科)

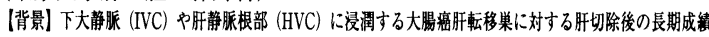

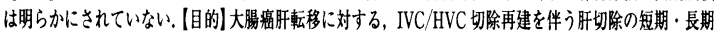

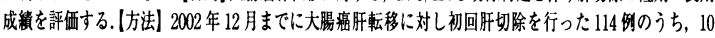

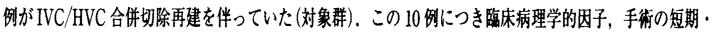

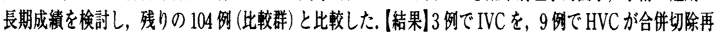

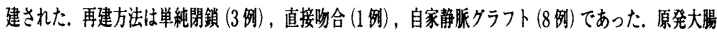

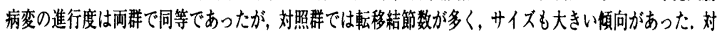

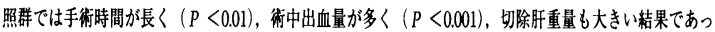

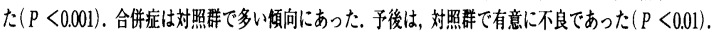

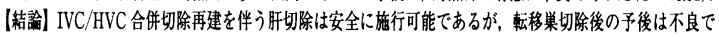
あった.この術式の survival benefitは，今後の症例蓄積により明らがするる必要がある。

PPB-3-170 大腸癌肝転移の術中診断

秦正二郎, 今村 宏, 青木 环, 橋本拓哉, 佐野圭二, 菅原寧彦,

國土典宏, 幕内雅敏

(東京大学肝・胆 - 羘外科)

【目的】大腸癁肝転移の術前診断と術中診断の相違について検討する.【対象】 2002 年, 2003 年の 2 年間に大晹㿋肝転移に対して肝切除を行った 102 例. [結果】術前に診断さ れた肝転移の個数は，最高 18 個，平均 2.8 個であり，実際に切除された個数は, 最高 25 個, 平均 4.2 個であった. 術中に新たな肝転移宩が発見された症例は, 術前診断 1 個の 症例が 44 例中 4 例 $(9.1 \%), 2-3$ 個の症例が 32 例中 12 例 (37.5\%)，4-5 個の症例が 11 例中 6 例 $(54.5 \%) ， 6$ 個以上の症例が 13 例中 9 例 $(69.2 \%)$ であり, 術前に診断された 転移の個数が多いほど術中に新たな病変が発見される割合が高かった。また切除された 転移巣 424 個のうち 135 個が術中に新たに診断され，そのうち視・触診のみで 103 個の 病変が発見されていた. IOUSのみで発見されたものは 12 個であった. 術中に新たに発 見された病変の大きさは 120 個が $10 \mathrm{~mm}$ 以下であり，また 123 個が肝表面から $10 \mathrm{~mm}$ 以下に存在しており，肝表面に近い小病変が術前に診断されにくかった. 結論了大腸癌 肝転移の手術の際は，視・触診およびIOUSによる術中診断が重要である。

PPB-3-171 大腸癌同時性単発肝転移の治療は一期的手術か待機手術 か? -残肝再発と病理学的検討一

小寺由人, 大坪毅人, 井上雄志, 桂川秀雄, 片桐 聡, 吉利賢治, 浜野美枝, 手塚 徹, 有泉俊一, 高崎 健

(東京女子医科大学消化器外科)

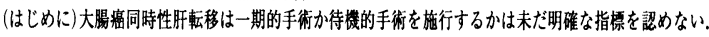

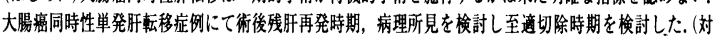
象)当科にて 1990 年加 1999 年に一期的切除された 27 例. (男 13 例女 14 例) (結果)残肝に再発した 症例は 27 例中 16 例. (59.2\%) 残肝再発例の平均無再発期間は 11 个月。初回手術後の锥察期間 11 个月

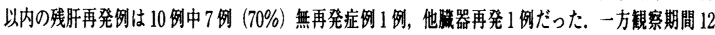

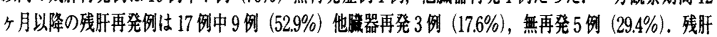

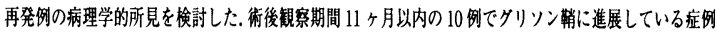

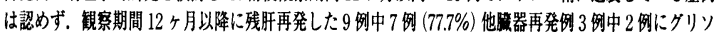

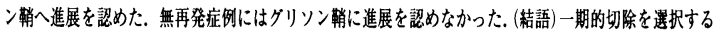

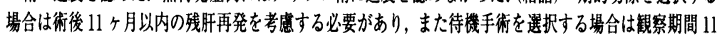
ヶ月を目途に道切な補助潦法を行いつつ二期的な肋切除術を考虑する必要が有ると考えられた。

PPB-3-172 胃癌肝転移症例の切除成績と予後因子の検討 米山泰生, 中郡聡夫, 小西 大, 高橋進一郎, 木下 平 (国立がんセンター東病院肝胆捇外科)

【背景と目的】胃癌の肝転移症例の切除成績と予後因子の検討を行った.【対象 と方法】対象は 1992 年 7 月から 2003 年 7 月に初回肝切除を施行した胃癌肝 転移 33 例. 切除適応は腫演個数 3 個以内で葉切除あるいは 3 ケ所の部分切除 で根治的切除が可能な症例とした. 臨床病理学的諸因子, 手術結果, 予後につ いて検討した.【結果】胃癌肝転移切除後の 5 年生存率は $15.9 \%$, 生存期間中央 值は 672 日であった. 肝切除後生存期間と有意に相関する予後因子は明かと はならなかったが, 5 年生存例を 3 例得られ，その 3 例には, 単発, 術式が系 統切除, 組織型が分化型の 3 つの共通点を認めた. 切除後再発例 24 例中肝転 移再発を 20 例に認め, 肝転移単独再発も 13 例に認めた。肝切除後, TS- 1 による補助化学療法を施行した 5 例中 1 例は転移巣 2 個であっても 816 日無 再発生存していた. 【結語】5 年生存例 3 例には単発, 系統切除, 組織型分化型 の共通点を認めた. 再発形式は肝転移が多く肝転移桑の control が重要と考え られた，また，補助化学療法については，更なる検討を要すると思われた。
PPB-3-173当科における胃教问時性肝転移症例に対する治療方法の 検討

三木克彦，山田行重，成清道博，高演 靖，上野正䦥，大東雄一郎， 王置英俊, 水野崇志, 中鳥祥介

(奈良県立医科大学第 1 外科)

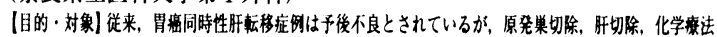

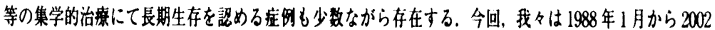

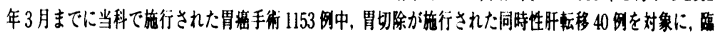

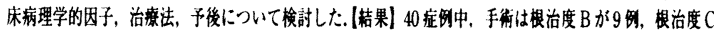
が31 周であった。根治度 B

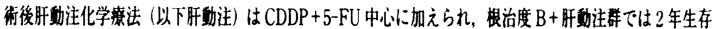

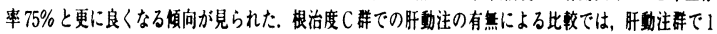

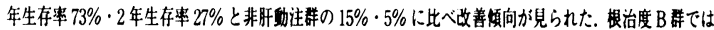

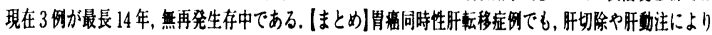

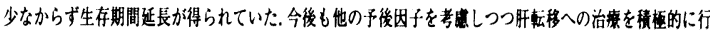
うべきで，これら集学的治菜により，長期生存か得られる叮能性があると考えられた。

PPB-3-174 進行胃瘦肝転移の外科的治療：肝切除と局所瘦化旗とし て徐放化抗癌郕の臨床忍用を目指して

水野 勇 ${ }^{122}$, 毛利紀章", 安田 影", 松本幸三”, 品川長夫", 赤毛義実 ${ }^{2}$ ，真辺忠夫 ${ }^{2}$

(名古屋市立緑市民病院外科"，名古屋市立大学第一外科 ${ }^{2}$ )

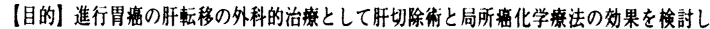

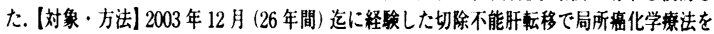

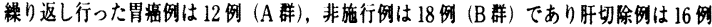

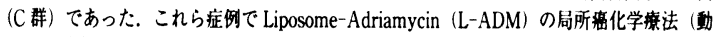

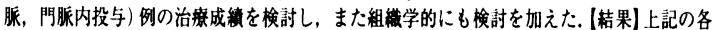

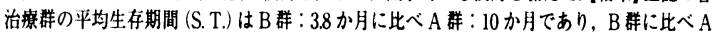

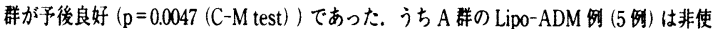
用例 (7 例) に比べ後良好 $(\mathrm{p}=0.003$ (C-M test) ) であった。一方C 群のS. T.は 22.4 か月

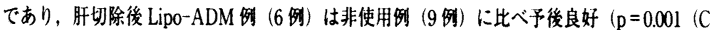

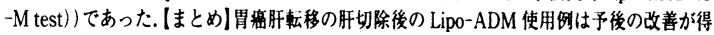
られた，非切除例でも Lipo-ADM 使用により PR，CRが得られた湖も経铁した。

PPB-3-175 大腸教肝転移に対する肝切除後再発防止について 松山 悟, 中房祐司, 北原蜸二, 下西智德, 大塚隆生, 宮崎耕治 (佐賀大学一般・消化器外科)

【目的】大晹癌の肝檕移症例について肝切除後の再発危除因子を検討するとともに再発 予防のための治療方法を検討した（対象】 2002 年までの 15 年間に大腸を原発巣とする 転移性肝㾇と診断された症例のうち原発紧が切除された111例を对象とした. 肝切除症 例は根治的肝切除が行われた 50 症例. (結果)肝切群, 非肪切群の 5 年生存事はそれぞれ $35 \%, 2 \%$ であり肝切群の予後が有意に良好であった $(\mathrm{p}=0.00)$. 深達度が ssまたは 1 以下の症例の肝切後 5 年生存率は $51 \%$, se または $\mathrm{a} 2$ 以深の症例の $23 \%(\mathrm{p}=0.01)$ て あったまた，原発巣にリン八゙節転移が無い症例，有る症例の 5 年生存率はそれぞれ $79 \%, 19 \%(\mathrm{p}=0.00)$ であった：これらの因子は多変量解析でも，また，再発生存率

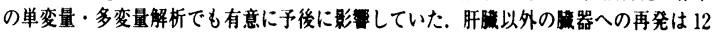
例認めているが肺の1例を除き，全例原発巣のリンバ節轱移を伴う症例であった。動注

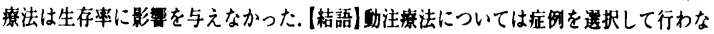

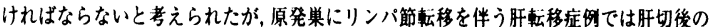
予防的全身化学療法が再発抑制に効果が期待できるものと考えられた。

PPB-3-176 大腸癌肝転移切除術後補助肝動注化学療法および非切除 例に対する肝動注化学撩法の効果

網倉克己"，坂本裕彦"，小林照忠"，西村洋治"，田中洋一", 島村智崇" ，山山研成”，多田正弘"'，中島哲夫 ${ }^{3}$

(埼玉県立がんセンター消化器外科", 埼玉県立がんセンター消化器内科", 埼玉県立がんセンター放射線科”)

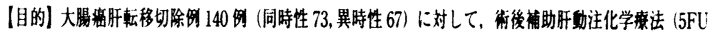

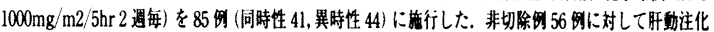

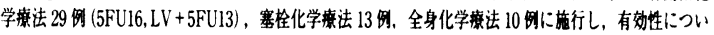

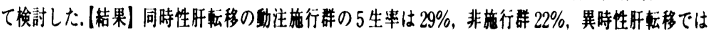

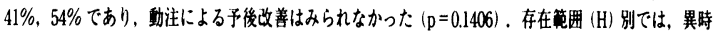

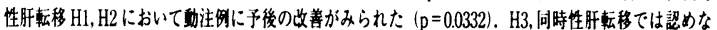

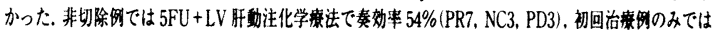

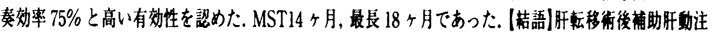

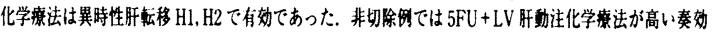

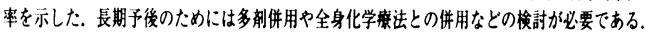


PPB-3-177 大腸癌肝転移術前門脈寒栓療法の安全性と有効性の検討 光永修一, 高棉進一郎, 小西大, 中郡聡夫, 木下 平

(国立がんセンター東病院肝胆滕外科)

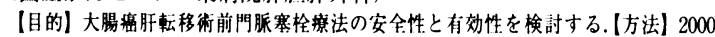
年 1 月より 2002 年 12 月に当院で門眽塞栓後に肝切除を施行した大腸密肝転移 5 例を

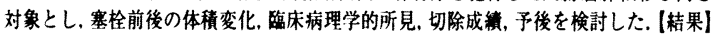

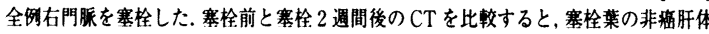

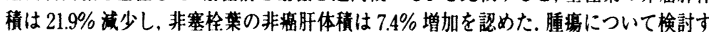

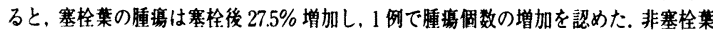

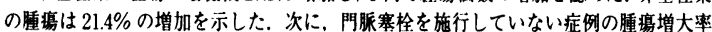

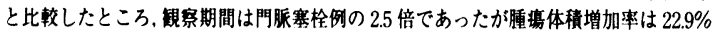
でありほほ同等であった。門㟲寨栓から平均 21 日で全例手術を施行した（右莱切除 3

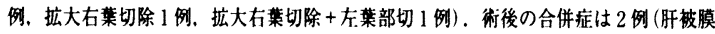

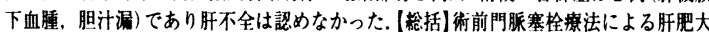
によって, 大晹癌肝転移症例の肝切除を安全に施行できた。しかし、門腺塞栓は腫韵を 增大させる可能性があり，塞栓後の腄堭增大に注意が必要と思われた。

PPB-3-178 抗癌郕感受性試験による切除不能転移性肝瘦の治療〜 Real time MRI ガイドト肝生検の有用性

塩見尚礼，来見良誠，仲 成幸，目方英治，内藤弘之，川口晃，

遠藤善裕, 花澤一劳, 谷徹

(滋賀医科大学消化器外科)

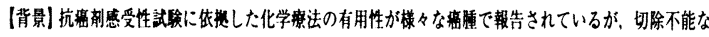

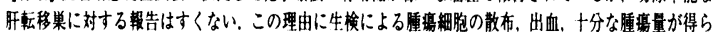

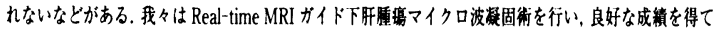

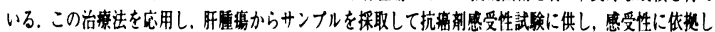

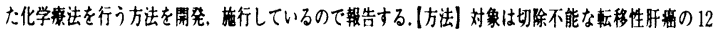

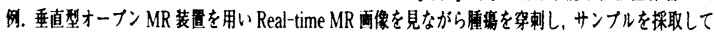

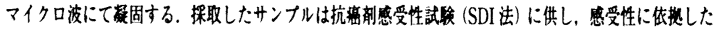

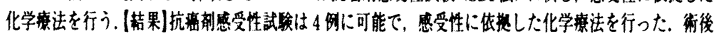

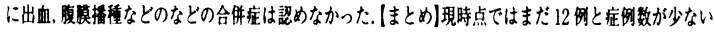

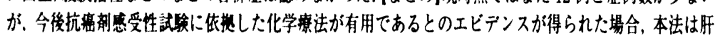

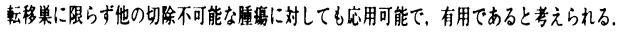

PPB-3-179 胃㿋・大腸病の同時性切除不能肝転移に対する持続肝動 注化学療法の検討

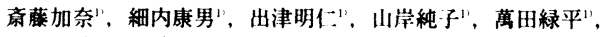

平山 功", 尾鴄 侣”, 西田保: ", 桑野博行"

(群馬県済生会前橋病院外科"，群馬大学第 1 外科 ${ }^{21}$ )

胃癌・大腸轁の同時性切除不能肝転移に对し術後持続肝動注化学療法を施行した. 【対象】期間：1998年 4 月 2003 年 8 月. 胃瘦 20 例（肝動注樟法施行群 13 例：非

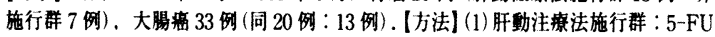
$500 \mathrm{mg} /$ 日の 24 時間持繶肝動注・ CDDP $10 \mathrm{mg} /$ 日点滴静注.し, 5 日間連続投与 · 2 日間休菜 (1 クール)を 4 クール施行後. UFT $300 \mathrm{mg} /$ 日の経口投与・5-FU 500 $\mathrm{mg}$ 肝動注および CDDP 20mg 点滴静注を biweekly (12 週間：外来) で交互に施行 した. (2) 非施行群：UFTの経口投与のみを行った，各群での奏効害および累積生

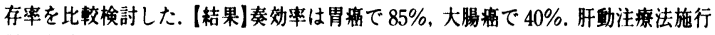
群：非施行群の 1 年生存率は，胃瘭で $82.5 \%: 50 \%$ (n. s.) , 大腸癌では $79.1 \%$ ： $48.5 \%$ で有意差が認められた $(\mathrm{P}=0.036)$. [考察]胃瘦, 大腸滛の同時性肝転移症例 に対し，CDDPの静注を併用した 5-FU の持繶肝動注化学橑法は有用である.

PPB-3-180 切除不能転移性肝瘦に対するレンチナンを併用した動注 免疫化学療法 (I-PMC 療法) の試み

上田祐二, 落合登志哉, 固山輝久, 内藤慶, 田儀知之, 阪会長平, 大辻英吾，系井啓純，萩原明於，山岸久 - -

(京都府立医科大学消化器外科)

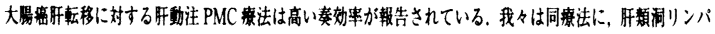

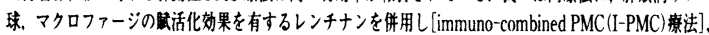

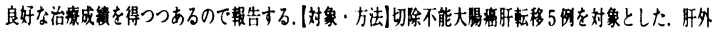

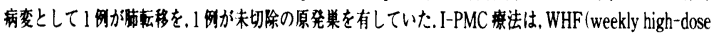

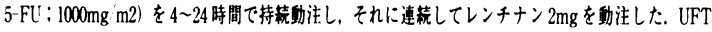

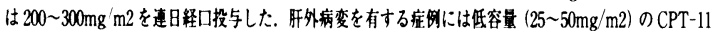

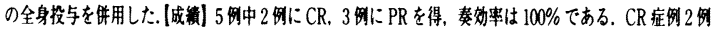

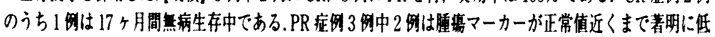

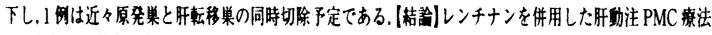

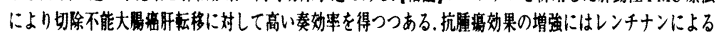

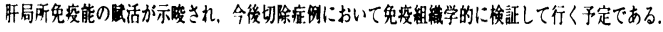

PPB-3-181 肝転移巣に対し根治術が困難であった大腸癌同時性肝転 移症例の検討

渡正志, 中崎晴弘, 瀧田 涉, 長谷部行健, 瀨尾晃朗, 種村宏之, 栗原聘元, 寺本龍生, 小林一雄

(東邦大学第 1 外科)

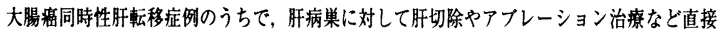
加㙩が行い得なかった症例について検討する. [対象および方法] 1991 年 8 月より 10 年間に 加㙩した原発巣未治療大腸癌 692 例のうち同時性の肝転移を有した症例は, 80 例であった. うち朋転移紧に対して直接治療できなかった 59 例のうち予後不明例，他病死例 12 例を除 いた 47 例を对象とし，生存期間別に，腹膜播種，遠隔転移，リンハ節転移，他滕器直接浸

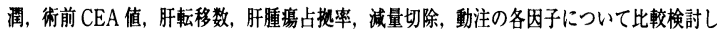
た. [結果] 原発集の切除不能例, 腹膜播種陽性例, 他滕器直接浸洞陽性例では 12 力以上 生存した症例は認めなかった，肝転移巣に対して減量切除ができ，十分な胿動注ができた症 例が長く生きられる㑯向にあった. [結語]切除やアフレーションにより肝腫場の減量し，長 期に動注を加えることが予後の改善につながるものと思われた．治療成績の改善のために は抗㿋郕の選択，長期に動注が可能なカテーテル㨉入術の工夫などが必要である。

PPB-3-182 胆管内腫瘍栓を伴った大腸㿋肝転移の切除症例の検討 杉浦禎一, 梛野正人, 湯浅典博, 小田高司, 新井利幸, 江畑智希, 二村雄次

(名古屋大学大学院器官調節外科)

<症例〉症例 1 . 上行結腸䍃に対し結腸切除施行. 9 年後, 肝転移 (S8) に対し肝部分切除 施行. 11 年 3 ケ月後, 肝転移 (S8) と胆管腫韵栓を認め肝搪大右葉切除, 肝外胆管切除施 行. 13 年 3 个月後現在無再発生存中. 症例 2 . 直腸癌に一直腸切断術施行. 4 年 4 个月後, 肝転移 (S4) 及び胆管内腫韵栓に対し拡大左葉切除, 肝外胆管切除施行. 8 年 1 力月後, 腾内胆管転移に対し膡碩十二指腸切除施行. 8 年 7 个月後, 肝転移 (S7) に対し肝部分切 除施行. 14 年 9 力月後現在無再発生存中. 症例 3 . 直腸窑に対し低位前方切除. 3 年 4 r月 後, 肝転移 (S8) と胆管内腫崵栓に対し肝右葉切除施行. 6 年 6 力月後, 肝転移 (S2) と 胆管内腫笉栓に対し外側区域切除施行. 10 年 9 个月後に他病死。症例 4 . 直腸癌, 肝転移 (S8) 及び胆管内腫葟栓に対し低位前方切除, 肝右葉切除施行. 10 个月後に癌死. 症例 5.

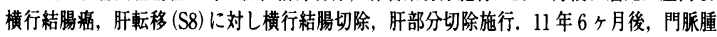

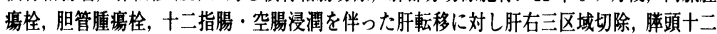
指腸切除, 門腺合併切除, 空腸合併切除を施行. 12 年後現在, 無再発生存中.

PPB-3-183 胆管浸潤を呈し肝内胆管癌との鑑別が問題となった大腸 癌肝転移症例の検討

中村啓之, 海野倫明, 片寄 友, 力山敏樹, 及川昌也, 山本久仁治, 松野正和

(東北大学大学院消化器外科学)

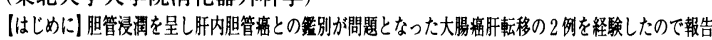

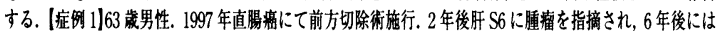

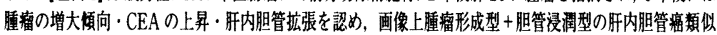

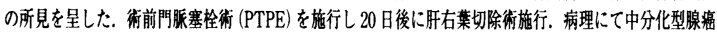

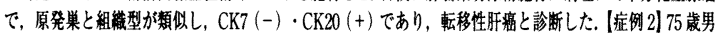

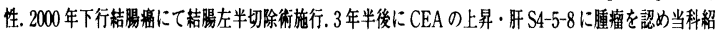

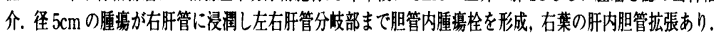

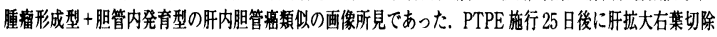

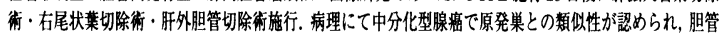

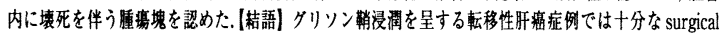

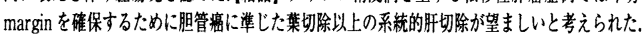

PPB-3-184 乳癌肝転移に対する肝切除の有用性の検討 末廣剛敏 ${ }^{2.2}$, 平下禎二郎 ${ }^{2 !}$, 荒巻政憲" ${ }^{2 \prime}$, 武内秀也 ${ }^{21}$, 增野浩二郎 ${ }^{21}$, 住吉康史 ${ }^{21}$, 桑野博行 ${ }^{11}$

(群馬大学第 1 外科"

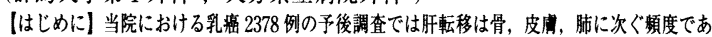
るが再発後生存期間は骨の 36 , 皮用の 53 , 肺の 22 个月に比べ 6 个月と短く, 肝転移が乳癌患 者の予後を左右しており肝転移がコントロールできれば予後向上が期待できる. 今回, 乳癌肝 転移切除例を検討した。 [対象と方法]転移性肝腫場切除例 14 例中乳㿋肝転移にて肝切除を行 なった 3 例を対象とし, 背景因子, 再発形式, 術式, 予後について検討した. [結果](症例 1) 54 藏女性, 同時性, 乳癌術後 3 个月後に $33-4$ 多発 $(35,25,15 \mathrm{~mm})$ に对し拡大左葉切除施行. (症

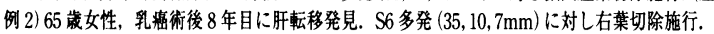
(症例 3) 70 紫女性, 13 年目に左葉に徍 $10 \mathrm{~cm}$ の肝転移発見. ポート留置し動注潦法施行. 腫 湢縮小効果あり㹡大左葉切除施行. 同時性は術後 3 个月で胓肺多発再発に対し化学療法を開

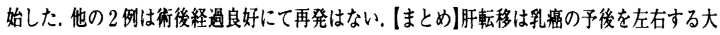
きな因子である，そのため, 他の再発と同じような全身的なホルモン治療や化学療法ではな く，局所を中心とした集学的治䤃が必要であり，乳癌肝転移に対する肝切除は有用である。 
PPB-3-185 進行肝門部胆管癌内瘦化困難症例に対する PTBD 内視 鏡的経皮経胃内瘦化術の試み

小島由光，中村昌樹，諏訪大八郎，鈴木 実

(公立森町病院外科)

【はじめに進行肝門部胆管癌は，姑息的減黄にすら限界がある。. 今回我々はPTBDチューフ

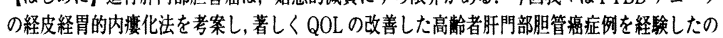
で, 本法の有効性に関して考察し報告する. (症例) 88 歳, 男性. 肝硬変, 痴呆あり。他院にて 肝門部胆管癌の診断で左肝管にメタリックステントを挿入された後，当院受診。来院時，T. bil

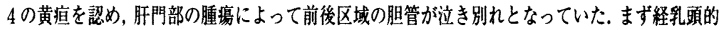
にEBD を挿入したが機能せず, S6 およびS7の末梢にPTBDを2 本挿入した。波黄によって全 身状態は改善し，在宅㞠養の妨げはチューフだけとなったこのため本法を考案しICをとった 後, 局所麻醉下に本内漠化術を行った. (方法I14G70 cm の IVH カテーテルをPTBDチューフと 入れ換え皮下で上腹部正中に誘導し，同部で内視鏡観察下にPEGの要領で胃壁を腹壁に固定し た後，シースを皮下から刺入しカテーテルを胃内人誘導した. [結果了術後21 日目に退院するこ とができ,再人院して死亡するまでの約 3 个月間の開存を確㥖した。(まとめ]本法は安全でが 低侵熋に患者のQOL 向上に寄与することができ，梗めて有用な方法であると考えられた。

PPB-3-186 切除不能胆道癌に対する胆道内贋術の検討 小山善久, 井上典夫, 早瀬 傑, 小船戸康英, 伊藤 淳, 佐久間浩, 大木進司, 畠山優一, 関川浩司, 竹之下誠一

(福島県立医科大学第 2 外科)

1987 年から 2003 年 3 月までに悪性胆道狭窄で根治切除不能のため Ex-

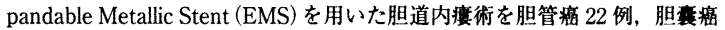
7 例の計 29 例に施行した。男性 13 例，女性 16 例で年齡は50-81 藏（平均 69.7 藏)であった. 22 例に Z-stent, 4 例に Wallstent, 2 例が $Z$-stent と Wallstent の併用, 1 例にZA stent を用いた. これらの症例について同時期に施

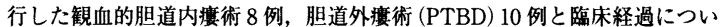
て比較検討した. 3 群間で生存期間に差はなかった. EMS 例と観血的胆道内 瘦術では PTBD 例に比較して無黄㾝期間や在宅期間が長かった。観血的胆 道内瘦術は黄疸再然が多く, PTBDの追加㨉入が必要な症例が多かった。 EMS は無黄㾝期間が長く, 胆管炎や黄疸の再燃が少なかった。切除不能胆 道癌の胆道狭窄の治療は EMS による方法が低侵熟で, 胆管炎などの合併症 も少なく，外来通院が可能で QOL の面からも優れていると思われた.

PPB-3-187 当科における胆管ステント治療

陣内祐二"1，小森山広幸"，戸部直孝"，奥村権太"，四万村司"， 川本久紀"，田中圭一" ，萩原 優"1)，山内栄五郎 2

(聖マリアンナ医科大学横浜市西部病院外科", 聖マリアンナ医科大学横 浜市西部病院放射線科 ${ }^{21}$ )

(目的)当科における胆道ステント治療の方法, 成績を報告し, その利点と問題点を検討 した. (対象) 1998 年 12 月から 2003 年 12 月までに胆道狭窄をおこし expandable metalic stent (EMS) 挿入した 61 例を検討対象とした. (方法) 閉塞性黄㾝に対してまず PTBD を挿入し，8.3fr のチューブを留置した，約 1 週間後に造影を施行し，狭空部の長さに合 わせて non-covered ステント LUMINEXX-TM の外径 10mmを標準として長さ 2-12 $\mathrm{cm}$ のステントを選択し留置した。 的 1 週間後に造影を行いチューブを抜去した（成縝）

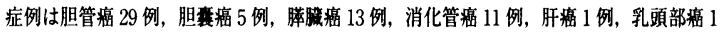
例，胆管狭窄 1 例であった. ステント個数は 1 個 29 例， 2 個 22 例， 3 個 6 例， 4 個 2 例, 5 個 2 例であった. 合併症は出血 2 例, 胆管炎 4 例であった（まとめ)胆管ステント 挿入は全例可能であった. ステントの $70 \%$ は有効に機能していた。 閉塞部位に応したス テントを用いることで患者のQOL 向上に大きく貢献していると考えられた。

PPB-3-188 閉塞性黄㾝に対する1期的経皮経肝的 Expandable Metallic Stent（EMS）捚入の検討

吉田 寛, 真々田裕宏, 谷合信彦, 川野陽一, 水口義昭, 清水哲也,

高橋 翼, 有馬保生, 内田英二, 田尻 孝

(日本医科大学第 1 外科)

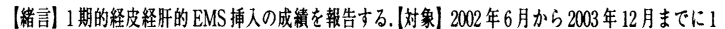

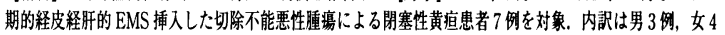

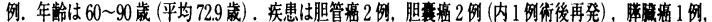

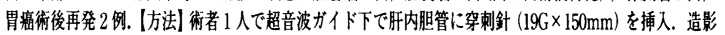
後ガイドワイヤー $(0.035 " \times 150 \mathrm{~cm})$ を進めカテーテル $(17 \mathrm{G} \times 270 \mathrm{~mm})$ 捙入し佛窄部を抬張。カテーテル

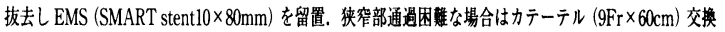

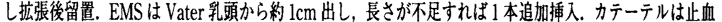

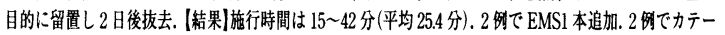

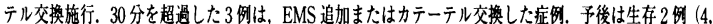

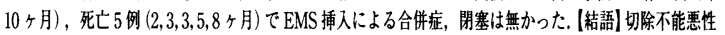

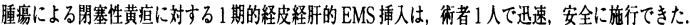

PPB-3-189 胆管ステント留置 2 年後に根治手術を成しえた高齢者十 一指腸乳頭部㾰の・例

冬廣雄彦, 山田忍, 山添定明, 山崎政直, 康 純明, 新田敦範, 田中肇

(生長会府中病院外科)

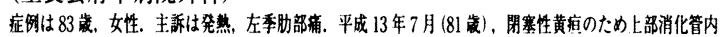

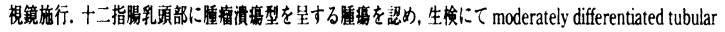

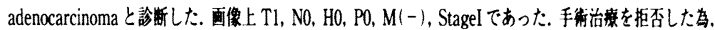

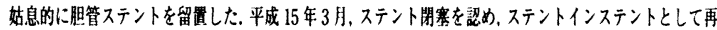

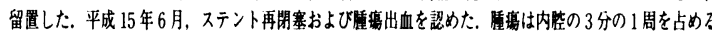

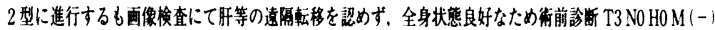

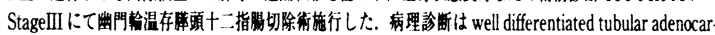

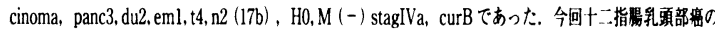

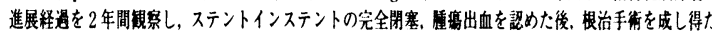

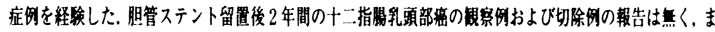

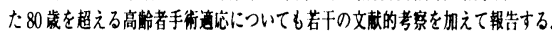

PPB-3-190 切除不能胆管癌に対する体外照射・胆管腔内照射併用金 属ステント留置

及川昌也, 海野倫明, 片寄 友, 力川敏樹, 山本久仁治, 松野正䄫 (東北大学大学院消化器外科学)

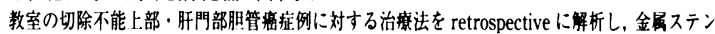
卜 (EMBS) 留置, および体外・些内照射 (RALS) 併用の意義に関して検討した。これまで切 除不能症例に対して, ${ }^{\circ} \mathrm{C}_{0}-\mathrm{RALS}, \mathrm{EMBS}, \mathrm{EMBS}+$ chemoradiation なとの治革を行ってきたが，

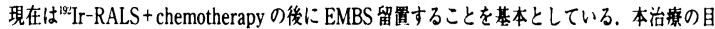

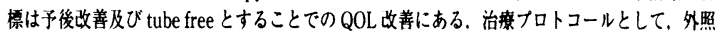

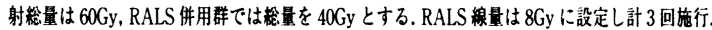
さらに症例の performance statusに考虑しながら low dose FP 化学镜法を付加する。最䅂的に

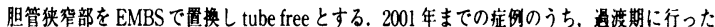
EMBS 単独例 $(n=24)$ の平均生存期間 5.2 ケ月に对L, ${ }^{\infty} C_{0}-\mathrm{RALS}$ 例 $(\mathrm{n}=30) 19.3$ ヶ月, EMBS+ chemoradiation 例( (完遂例 $n=26) 21.0$ ケ月で，集学的治㿋により䄪 1 年の予後改善が得られた。

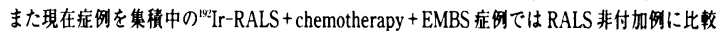
し EMBS 開存期間が延長する熄向であり，QOLに省与していると考元る。

PPB-3-191 QOL を重視した悪性胆道狭窄に対する EMSの適応の検 討

萩原 謙"，伊藤 豊"，植田利貞"，原回義坐"，倉本畫明 ${ }^{2}$

(国立病院東京災害医療センター外科"，国立病院東京災害医療センター 放射線科”)

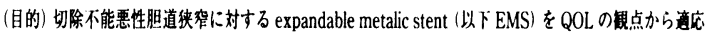

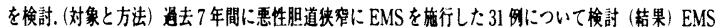

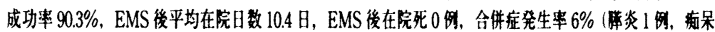

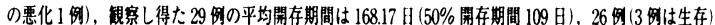

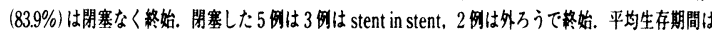

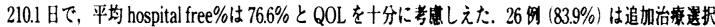

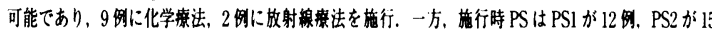

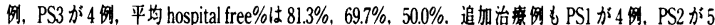

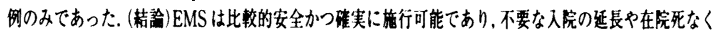

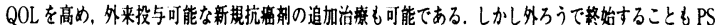

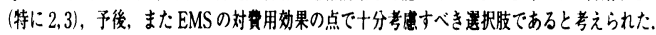

PPB-3-192 腹腔鏡下胆塞摘出術における胆喜管走行異常例の検討 中川国利，白相 悟，中川康彦，嗃藤公人，铃椟幸正，桃野 哲 (仙台赤十字病院外科)

DIC-CTによる胆毫管走行異常の形態および胆蓑管走行異常例における腹 胫鏡下胆赛摘出術の問題点について検討した. (対象】過去 20 ヶ月間にDIC ーCTを施行した 353 例を対象とした. (結果) 胆謇管閏塞は 101 例で認めた が, 胆典管がまったく造影されなかった例は５例のみであった。また胆衰管 と右肝管とが近接していた 3 例では，解剖学的位置関係を術前には把握で きなかった，胆菷管の走行異常を 77 例で認めた，胆管損伤は 2 例で生じた が，術前に胆算の走行異常を診断できた 76 例では胆管損傷はなかった。

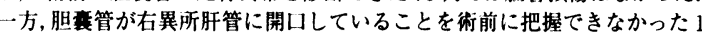
例で，右異所肝管を切離した．また総胆管結石を合併した慢性胆豪炎の1

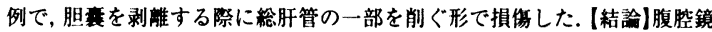
下胆塞摘出術における胆管損侮を避けるためには，胆莘管の走行を術前に 把握しておく必要がある. DIC-CT はいまた解像力に問題があるが, 容易に 胆道を三次元的に検討できるため，術前検査として大変有用である。 
PPB-3-193 腹㓐镜下胆亳摘出術における開腹移行例についての検討 平井俊男, 八十川要平, 西 八嗣, 神行紀輝, 高橋禎人, 近藤康史, 㮛井雅之, 升水康一，小野里航，小川巷史 (北里研究所メディカルセンター病院外科)

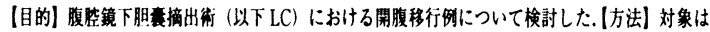

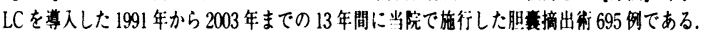

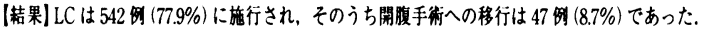

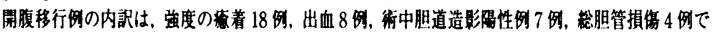

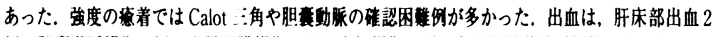

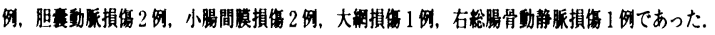

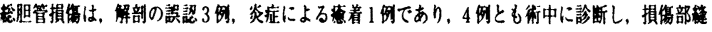

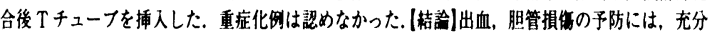

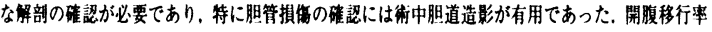

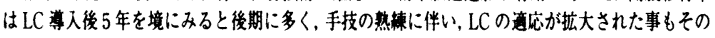

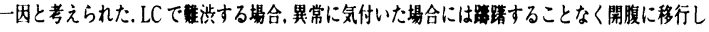
此血や俊復等を速やかに行う事がその後の合併症をより少なくする方法と考えられた。

\section{PPB-3-194 胆喜管が肝右葉胆管枝と合流する症例に対する腹腔鏡下} 胆赛摘出術

森 俊治, 長谷川洋, 坂本英至, 小松俊一郎, 公松 孝, 德丸勝悟, 河合清貴, 田㚼智丈, 深見保之

(名古屋第二赤十字病院外科)

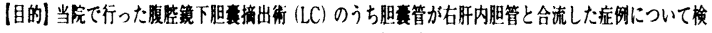

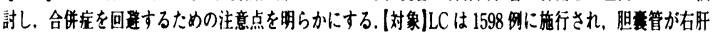

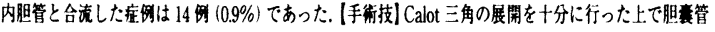

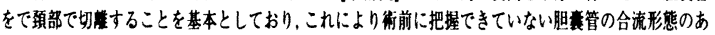

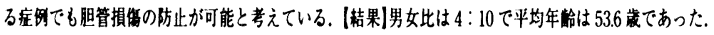

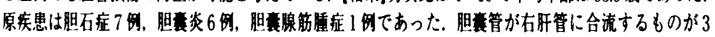

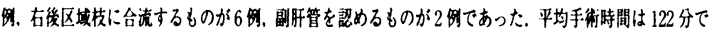

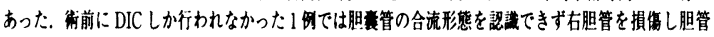

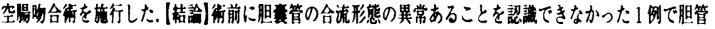

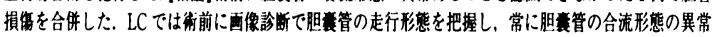

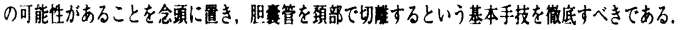

PPB-3-195 当院における腹腔鏡下胆蒦摘出術-開腹移行例の検討 大坪義尚, 平野純子, 今中售弘

(井上記念病院外科)

【目的と方法】腹㓐鏡下胆蓄摘出術 (LC)における開腹移行例とその理由について, 導入早期 (H7 10：上腹部手術既往症例と，術前 1 ヶ月以内に発作のあった急性胆

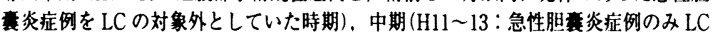
の対象外としていた時期)，後期 (而症例とも LCを試みた時期) の 3 群に分けて検 討した. (結果と考察】早期群 61 例中開腹移行例は 10 例で，理由は A. Calot三角の展

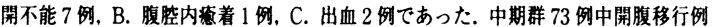
は 5 例で, A. 2 例, B. 1 例, C. 2 例であった. 後期群 56 例中開腹移行例は 5 例で,

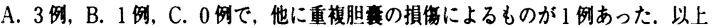

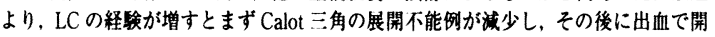
腹移行となる症例が娍少することが示唆された．また上腹部手術既往症例は中後期 群 129 例中 5 例あったが全例 LC 可能であった。急性胆衰炎症例は後期群 56 例中 20 洌あり，そのうち 4 例が開腹に移行していた，急性胆塞炎症例を発作から手術までの 期間が 2 莮間以内とそれ以降とに分けると而者の開腹移行事に差はなかった。

PPB-3-196 音声コントロール式手術ロボットAESOP の有用性の検 討 柴田邦隆，福崎孝幸，濱野梨絵，西田尚弘，筱木信钽，富永修盛， 松田泰樹，立石秀郎，小林折郎

(市立池田病院外科)

(目的】音声コントロール式手制ロホホット AESOP (以下 AESOP) の surgical assistant としての)有用性に

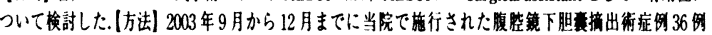

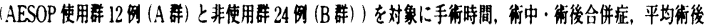

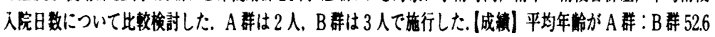

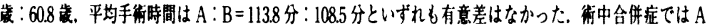

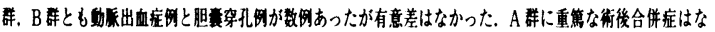

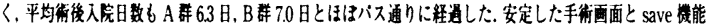

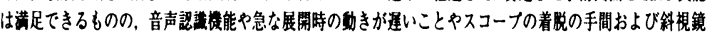

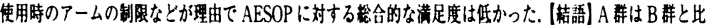

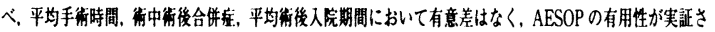

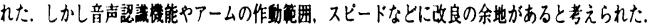

PPB-3-197 棇胆管結石に対する腹腔鏡下総胆管切開切石術 (LCBD） - 一期的連紜䋖合の検討

有馬保生, 横室茂樹, 吉田 寛, 野村 務, 真々田裕宏, 相本隆幸, 谷合信彦, 中村慶春, 山下精彦, 田尻 孝

(日本医科大学大学院臟器病態制御外科)

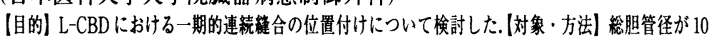

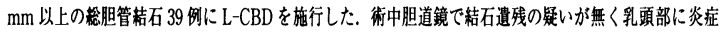

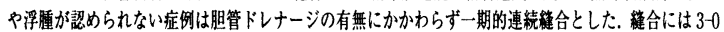

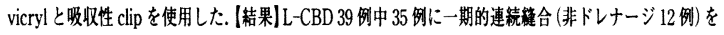

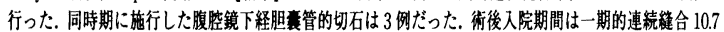

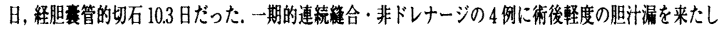

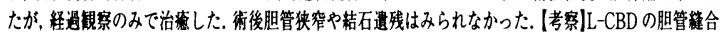

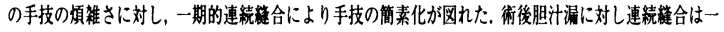

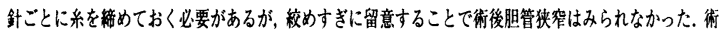

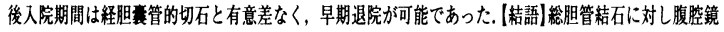

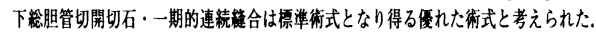

PPB-3-198 PTGBD 後に鏡視下手術を行った特発性胆裹穿孔の一例 西原雅浩, 杉野圭三, 春田直樹, 新原 亮, 矢野将嗣, 川口康夫 (あかね会土谷総合病院外科)

症例は 70 歳女性. 右上腹部痛・発倱で来院. 上腹部に圧痛および筋性防御を認め 䋈急入院となる. 白血球 $10200 / \mu \mathrm{ml}$, 血小板 $4.0 / \mu \mathrm{ml}, \mathrm{CRP} 26.16 \mathrm{mg} / \mathrm{dl}$, エコーで

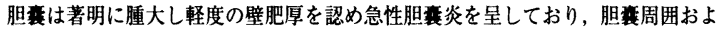
び肝表面・肝左葉下面に腹水を認めたが胆石は認めなかった。 CT 検查ではさら に胃体部前壁㑡に $3 \mathrm{~cm}$ 大の滕場を認めた. PTGBD を施行したところ造影剂の腹 胫内漏出が確認され, 3 日後に腹胫鏡下に胆毫摘出術を施行した. 胆衰を含めて肝

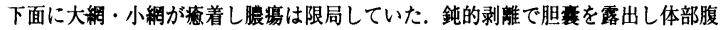
㑡に $15 \mathrm{~mm}$ 大の穿孔を確認した. 切除標本では胆塞壁は軽度肥厚し粘膜の色調は 良好で通常の壊死性胆諅炎とは異なり, 病理組織検査で粘膜は部分的に高度な変 性塤死に陥り穿孔部周辺の血管には血栓形成が認められ, 胆塞部分梗塞による特 発性胆萲穿孔と考えられるまれな症例であった。術後合併症無く軽快退院した. 腹腔内膿場を伴う胆襄穿孔症例であったが PTGBD 等迅速な処置により腹腔鏡 下胆豪摘出術の低侵襲手術のメリットが活かされた症例である.

PPB-3-199 腹腔鏡下胆衰摘出術により診断し得た胆唄管走向異常を

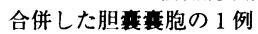

平能康充, 龍沢泰彦, 木下静一, 清水淳三, 川浦幸光

(済生会金沢病院外科)

【宊例】 49 歳，女性. 1997 年に胆石を指摘されたが放置していた，2003年 9 月より上腹部 の鹤满感が出現したため近医を受診し当院紹介となった. 腹部 US・CT 検查で胆言内結石

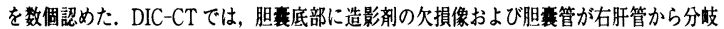

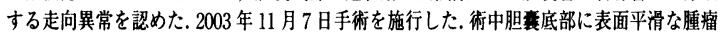

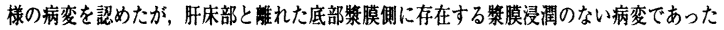

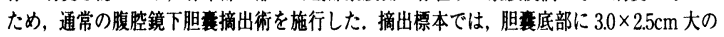

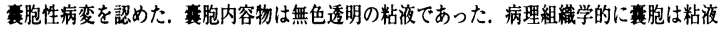
性の円柱上皮で形成されていた. [考察] 胆莗䡒胞は非常に稀な疾患であり, 治療方針に関 した確固たる指針はないが，萁胞内皮の一部に乳頭状腺癌や異型上皮を認めたとの報告も あり，診断的治类としても第一に腹䏝鏡下胆蘘摘出術を含めた切除を考虑すべきと思われ る.また，胆塞管走向異常を合併した胆衰疾患に対する腹脘鏡下胆褰摘出術では胆道を損 傷する可能性があり，術前にDIC-CT にて胆道系を評価することが肝要である。

PPB-3-200 腹腔鏡下胆蓑摘出術困難例に対する工夫〜術前 ENBD 挿入の有用性一

亀山哲章, 田野敦子, 壁島康郎, 戸泉 篤, 田村洋一郎, 影山隆久 （国立霞ヶ浦病院外科）

当院では現在，原則として胆衰摘出術を施行するすべての症例に対し腹腔镜下胆蘘摘出術(以下 LC) を施行している. しかし炎症の強度な症例は開腹移行例も少なくなく，開腹移行例の理由 の多くがCalot's triangle の炎症・苟着により胆蒦管の同定が困難なことである.このような困 鹳例に対して2001 年より術前にENBDを留置し手術を施行している. 2003 年は当院における LC79 例中 16 例に術前に ENBD を挿入した. 腹腔镜手術を完遂し得た症例 11 例のうち 5 例は ENBDを㨉入していなけれは開腹手術に移行していた症例と思われた，ENBDの利点は，総胆 管を確実に同定できることや術中に何度でも造影できることや胆管掑傷が起こった場合維合閉 鎖しやすいことなとがある，次点としては ERCPを施行することによる偶発症の発生やチュー フの違和感などがある。当院では術前日ないし術前々日にENBDを挿入しており，現在まで 27 例と症例数は少ないが $\mathrm{ERCP}$ 後勝炎のため手術を延期した症例は 1 例のみであった. (結吾) LC 困鞾例に対する術前 ENBD 挿入は，ERCPによる偶発症の問题はあるが，開腹手術移行例で あった症例をより安全に腹堙鏡下手術にて完遂できる可能性を高めると思われる。 
PPB-3-201 鏡視下胆摘術における術前超音波所見のスコア化による 手術困難度の評価

木村 徹, 金田悟郎, 熦谷美奈, 香取玲美, 鎌田弘樹, 岸本一郎, 金澤秀樹，井上準人，西山保比古，秋山憲義

(国立相模原病院外科)

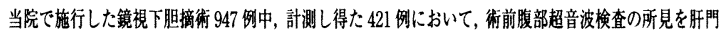

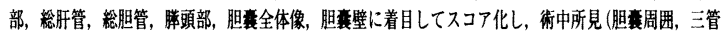
合流部, 肝床部)，手術時間，術中出血量，気腹時間，気腹量，術後在院日数，術中合併症の発生䫋度と

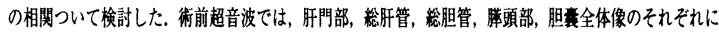

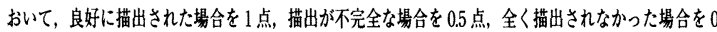
点とし䛨価し, 䏹算については $3 \mathrm{~mm}$ 末渾を 0 点, $3 \mathrm{~mm}$ を 1 点, $4 \mathrm{~mm}$ を 2 点, $5 \mathrm{~mm}$ を 3 点, $6 \mathrm{~mm}$

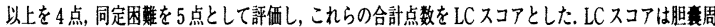

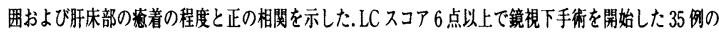

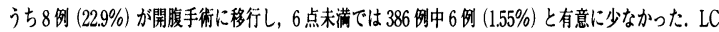

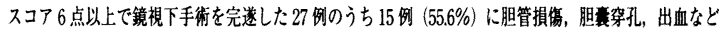
の術中合併症が発症し，6点末满で 380 例中 54 例（14.2\%）と有意に少なかった。

PPB-3-202 ハイリスク患者の腹腔鏡下胆衰摘出術における吸収性ク リップ使用は信頼できる

矢野将嗣", 杉野圭三", 川口康夫", 大下彰产", 西原雅浩",

新原 亮", 春田直樹 ${ }^{21}$, 渡辺浩志"

(あかね会土谷総合病院外科", 広島大学第 2 外科 ${ }^{2}$ )

(粕言) 近年，道残した金属クリッフによる晩期合併症が報告されるようになり，吸收性クリッフが

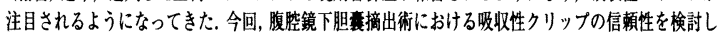

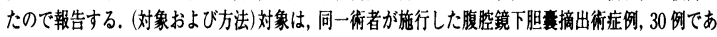

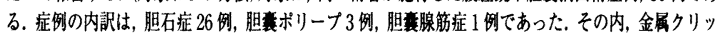
フ使用群は14例，吸収性クリッフ使用群は 16 例であった。金属クリッフ使用群と吸收性クリッフ使 用群の 2 群を比㜞娭討した。(結果) 2 群間に, 手術時間, 在院日数, 術後合併症の発生率等に有意差 は認めなかったが、胆筫管クリッナ数は吸収性クリッフ群で有意に少なかった。吸収性クリッフ使用

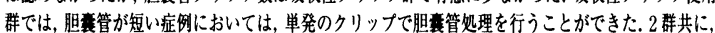

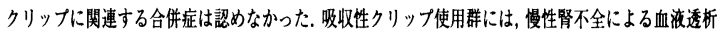
施行中のハイリスク症例が 2 例あった。(結語) 胆嚾管の短い症例や血液透析患者というハイリスク

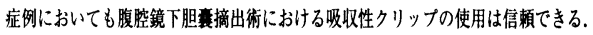

PPB-3-203 当院における腹腔鏡下胆塞摘出術クリニカルパス改訂の 経緯と効果

谷口正次, 指宿一彦, 山本 淳, 勝田和信, 後藤 崇, 中島 健, 加治 建，金中直輔，河野通一，古賀和美

(同心会古賀総合病院外科)

ははじめに当院におけるクリニカルバス（以下，パスの目的は主に診療業務の合理化にあるが，ハ

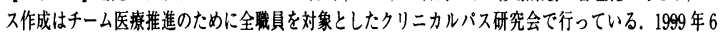
月に腹壁鏡下胆粪摘出術のクリニカルパス（以下，LCパス）を作成し，以降 4 回の改訂を行って2003

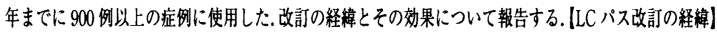
第1 版のパスは, 1700 例の LC 経駼をもとに現行の医療行為をまとめたものであった.2001年 4 月エビ

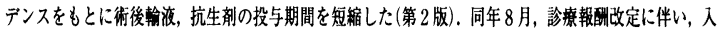

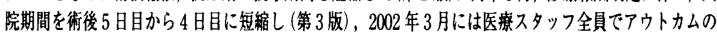
設定,介入について検討してアウトカムを盛り这んだパスを作成した(第4 版).2002年11月には看鿁

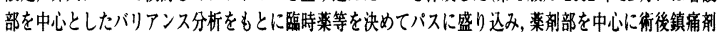

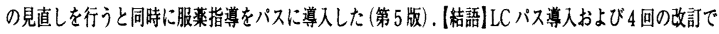
業務の効率化が達成されたと同時に，得られた最大の効果はチーム医㞠の推進であった。

PPB-3-204 腹腔鏡下胆赛摘出術における術中胆道造影の功罪 松本 潤, 高西喜重郎, 井上 仁, 足立健介, 大島 哲, 高見 実 (東京都立府中病院外科)

腹膑鏡下胆塞摘出術(ラパコレ)における術中胆道造影の意義を険討した，造影は術者の 判断で行い, 癌疑診例では禁忌とした。造影には $14 \mathrm{G}$ の血管留置針と $4 \mathrm{Fr}$ アトムチュー ブを用いた．最近 5 年間に 400 例のラパコレ（総胆管切石例を除く）を施行し 249 例 (62.3\%)で造影した. 24 例 $(6.0 \%)$ は造影不能だった. 最多理由は胆婁管にアトムチュー ブが挿入できずだった．造影 14 例, 非造影 7 例の急性胆塞炎が含まれた。開腹移行はそ れぞれ 14 例 $(5.6 \%), 9$ 例 $(6.0 \%)$ で，理由は造影例では胆莘管ないし胆管損稘疑い 6 例, 高度の炎症や瘾着 4 例, 出血 2 例, 瘦の疑い 1 例, 胆塞管結石 1 例であり, 非造影例 では全例が高度の炎症や虑着だった。造影 3 例で緿胆管切開となったが鏡視下に修復し， 3 例で総胆管結石を発見し経胆豪管的に切石した。一方 2 例で術後遗残結石を認め内視 鏡的に切石した。手術時間は造影例 $151 \pm 64$ 分にたいし非造影例 $119 \pm 48$ 分であり造影 例で延長した。しかし造影による合併症は見られず術後在院日数に差はなかった。造影で 総胆管噰断は避けられ新たな総胆管結石が発見しうる。.さらに総胆管結石治旗の技術習 得や教育の面からもラパコレでは術中造影が有用でルーチンに行うべき手技と考える.
PPB-3-205 腹腔鏡下胆基摘出術時における胆汁培養の検討 德原 真, 合田良政, 横皇德祐, 出11倫明, 山澤邦宏, 枝元良広, 寺島裕夫, 谷 晶尚, 清水利夫

(国立国際医撩センター外科)

【目的】腹胫鏡下胆塞摘出術時における胆计培養の結果について検討する. (症例と 方法】2001年1月から 2003 年 12 月までに腹㒄鏡下胆摘術が行われた症例のうち 胆汁培養が叮能であった 113 例を对象とした. 【結果】 113 例中 36 例 (31.9\%) に細 菌の発育を認めた，男女別には細菌陽性害で大きな差は認めなかった。年代別では 50 嵅代以上で細菌陽性率が高かった。術前に胆道ドレナージ行われた症例や筑胆

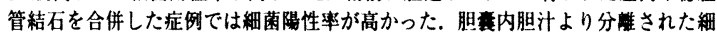
菌は 48 菌株であり, 練菌の内訳は Enterococcus が $20.8 \%$ と最も多く, 続いて $\mathrm{E}$. coli $18.8 \%$, Streptococcus $14.6 \%$, Klebsiella $12.0 \%$, Enterobactor $10.4 \%$ な゙が多 く検出された。嫌気性菌は Clostoridum のみで真菌は検出されなかった.クラム陰 性菌の占める割合は $56.3 \%$,クラム謁性菌は $41.7 \%$ であった.(まとめ)腹胫鏡下胆 摘術時においても従来の報告と同様, 高齢者や繶胆管結石で細菌陽性率が高かっ たししし分離した練菌株ではクラム陆性菌の占める割合がやや多かった。

PPB-3-206 腹腔鏡下胆喜摘出術後の合併症子測因子の検討 松尾浩, 木山茂, 宮原利行, 古田直偻, 関野考史, 山田卓也, 竹村博文

(岐皁大学第 1 外科)

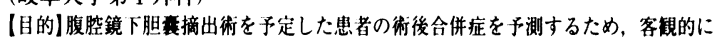
評価可能な因子について検討した. [方法] 1992 年から 2002 年に歧皁大学第一外科 で腹腔鏡下胆塞摘出術のみを子定した 95 例を対象とした。術後何らかの合併症をき たした症例は 20 例で, 内訳は創感染, 黄疸, 高アミラーゼ血症, イレウスなどであっ た. 年龄, 性, 入院時血液検査, 心電龱书よひ呼吸機能, 動㟲血ガス分析, 堅機能検 查, BMI, Brinkman Index, 既往楚, 術前 PTGBD, 発症からの目数を術前因子, 出 血量, 手術時間, 開腹術への移行, 術中造影, 腹脿内への胆汁晹出を術中因子とした. ロジスティック回淿分析を用いて単変最解析, 多変量解析を行った. P<0.05を有意 とした. [結果]単変量解析では腹燃內への胆汁漏出, 呼吸器疾患の既往, BMI, 血清 T-cho 值および Alb 值が有意な因子として，また多変量解析では腹脉内への胆计漏

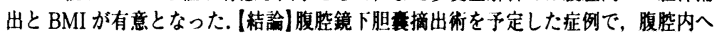
の胆汁漏出と BMI が独立した術後合併症危険因子として選択された。

PPB-3-207 腹腔鏡下胆貫摘出術における抗生剂子予防投与の検討

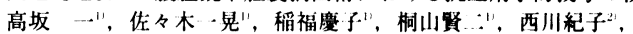

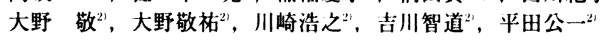
(道都病院外科", 札㹸医科大学第 1 外科 ${ }^{2}$ )

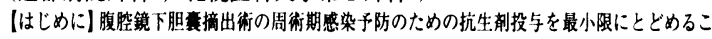

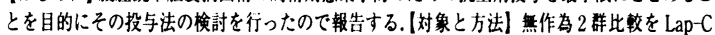

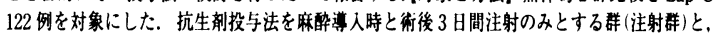
麻醉導入時と術当日夜の 2 回のみを注射で投与，その後は経山で 3 日間投与する群(経口辟) とし，この 2 群間で術後感染症発生を比较した，術後感染症は 38 度以上の発等, 術後 5 日目

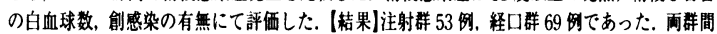

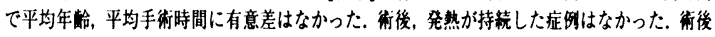
5 日目の白血球数が 10000 以上であったものは注射群，程山群おのおの1列ううにみられた。 創感染が注射群 3 例，释口群 1 例に発生したが有意差はなかったここれら手術部位感染のあっ た症例の平均手術時間は 100 分で，感染なしの群では 87 分で间者間に有意差はなか力た。 とめ)1. 注射群と経口で手術部位感架の発生事に差がみられなかった。. 2 今後はさらに投与 期間の短縮が可能と考えて手術日のみの抗生都投与として㛟討を開始している.

PPB-3-208 腹㬴鏡下胆塞摘出術の術中・術後に判明した胆黄癌症例 の検討 渡造 学, 炭山嘉伸, 柁原去久, 中村光彦, 田中英則, 楼本俊行, 浅井浩司, 長尾二郎, 草地信也, 斉田芳久 (東邦大学第 3 外科)

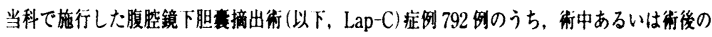

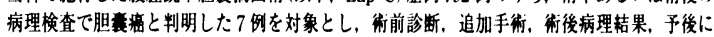

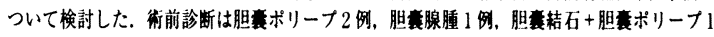

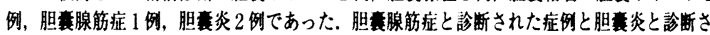

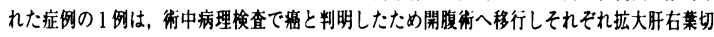

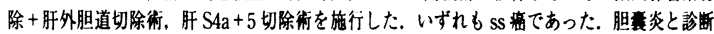

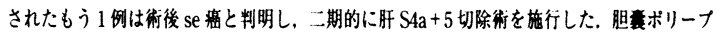

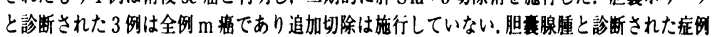
は mp 㿋であったが第1群りンバ節部清しており追加切除は施行していない. Lap-Cのみの

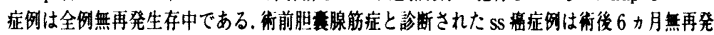

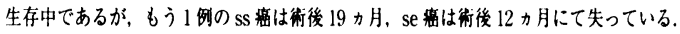


PPB-3-209十二指腸乳頭部腫㾨に対して経十 : 指腸的孚頭切除を 行った 4 例

旭吉雅秀"，大内田次郎"，千㛧一男"，汇藤忠明"，牧野一郎"， 甲斐真弘"，近藤千博"，畠山金太 ${ }^{-32}$ ，伊藤浩史

(宮崎大学第 1 外科"，宮崎大学医学部第一病理" ${ }^{2}$, 宮崎大学医学部第二.病 理 $\left.{ }^{3 \prime}\right)$

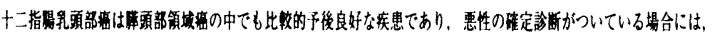

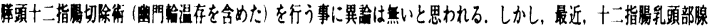

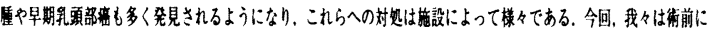

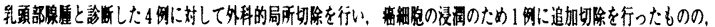

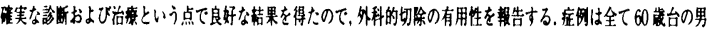

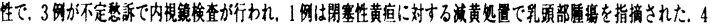

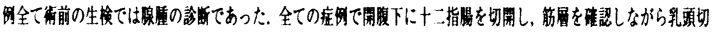

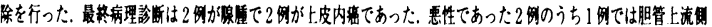

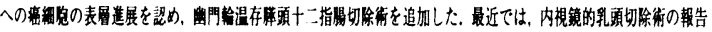

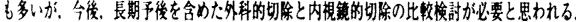

PPB-3-210 進行度からみた十二指晹乳䫓部稻切除症例の検討 平田建郎, 味木徹夫, 堀内秀樹, 美田良保, 藤野泰去, 上出 隆, 酒井哲也，谷岡康喜，铃朴康之，黒田嘉和

(神戸大学消化器外科)

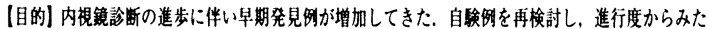

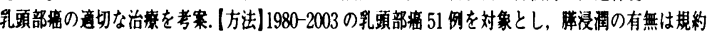

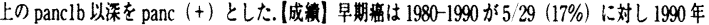
以降は $1023(43 \%)$ であった. また，1990年以降では panc0, dul が8例 (35\%) と增加していた。 3 生率。 5 生事は panc $(+)$ 症国 $22.2 \%, 22.2 \%$, panc (-) 症例 $78.4 \%, 63.0 \%$, du0 症例 $100 \%$, $66.7 \%$, dul 症国 $90.0 \%, 75.0 \%$, du2 以上庭何 $31.8 \%, 31.8 \%, \mathrm{n}(+)$ 症例 $42.8 \%, 14.3 \%, \mathrm{n}(-)$ 庭例 $76.9 \%, 71.0 \%$ で panc(+)，n(+)，du2 以上の症侧がそれぞれ有意に予後不良であった 1990

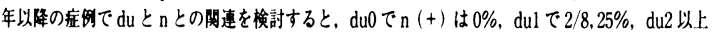
で2 $5.40 \%$ と用方進展とともにリン八節枟移事の增加を認めた。単変量解析，多変量解析ともにn

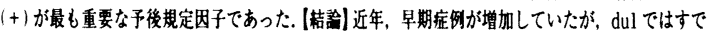

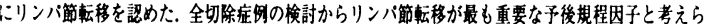

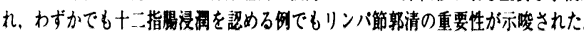

PPB-3-211 早期十二指腸乳頭部病に対する外科治㞠縮小化の可能性 折田雅彦，野島真治，梗 忠彦，重田匡利，原田栄二郎，濱野公一 (山口大学第 1 外科)

[目的]十二指晹乳頭部雷に対する根治術としては幽門输温存滕頭十二指晹切除術が選 択されるのが一般的であるが, 早期症例に対する樎小手術の可能性を検討するために当 科で释験した乳頭部整の成䋖を評価すると共に，内視鏡下粘膜切除 (EMR) 後に追加切 除を要した1例の詳細な病理学的検討を行った. [対象と方法] 過去十年間に当科で経験 した乳䫓部瘦 18 例を対象とし，蹦床病理学的因子と予後を検討した. [結果] 術式は

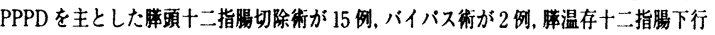
却分節切除術が 1 例であった。 病期は I が 4 例，II が 7 例，III が 2 例，IV が 5 例であっ た. 組蟣型が稀少なものとして small cell carcinoma（neuroendocrine carcinoma）がl 例あり, stage II であったが術後 1 年 7 ケ月で死亡し予後不良であった。滕温存十二指 晹下行都分節切除術を施行した 1 例は, 当初生検で group III と診断されており, 経過钼

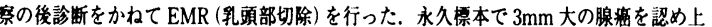
記の追加切除を行った. [桔語]肉眼的に早期と診断されるものに対し, 診断を萧ねた内 視镜下乳頭部切除を行うことは今後検討される余地が残っているものと思われた。

PPB-3-212榉体尾部欠損症と破格を伴う von Recklinghausen 病に 合併した十二指晹乳頭部癌の 1 切除例

飛田浩司 ${ }^{122}$ ，山崎一馬"，监玉多曜"，森川丘道"，外浦 功"，

松永晃直 ${ }^{1}$, 川村 功" , 落合武徳

(厚生連下都賀総合病院外科"，一千葉大学大学院先端応用外科学 ${ }^{21}$ )

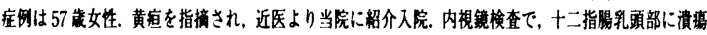

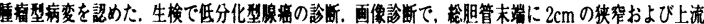

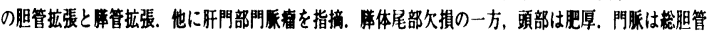

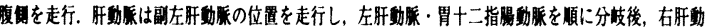

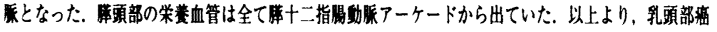

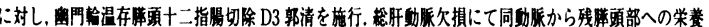

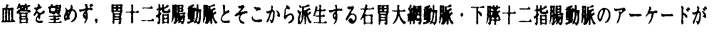

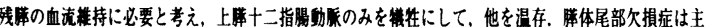

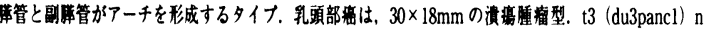

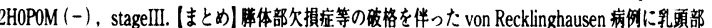

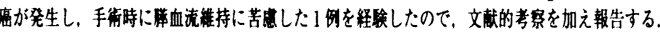

PPB-3-213 再発形式からみた十二指腸乳頭部癌に対する外科治療の 再評価

原豊, 袴田健一, 青木計積, 吉田 淳, 豊木器一, 十束英志,

鳴海俊治, 吉原秀一, 佐々木睦男

(弘前大学第 2 外科)

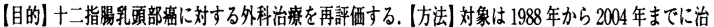
療した十二指腸乳䫓部癌 28 例のうち手術を施行した 27 测. 生存率, 再発率, 再発因子, 再発形式を検

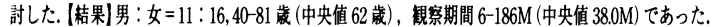

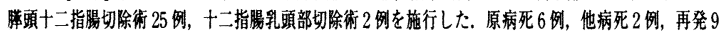

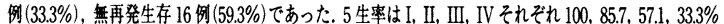
だった。再発因子はリンバ節転移の有無で， $\mathrm{n}(+)(10$ 例) と $\mathrm{n}(-)(17$ 例) の比較で, 再発率 $80 \% \mathrm{vs}$

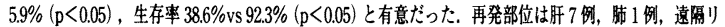
ンハ節 1 例とすべて遠隔転移再発であった，乳預部切除の 2 例は再発を認めなかった. [考察]乳頭部癌 に対するPpPD (D2+\#8，\#12) は，局所コントロールは良好であり，術式として妥当と考えられた。 \#8, \#12 転移例はなく，郭清を省略できる可能性がある，乳頭部切除の 2 例は無再発だが, 綟小手術の

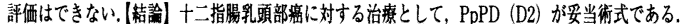

PPB-3-214十二指腸乳頭部癌におけるリンパ節微小転移の臨床的意 義 坂田英子, 白井良夫, 横山直行, 若井俊文, 黒崎 功, 野村達也, 北見智恵, 黒崎 亮, 畠山勝義 (新潟大学大学院消化器 - 一般外科)

【目的】十二指腸乳頭部癌におけるリンハ節微小転移の臨床的意義を明らかにする。【方法】十二指腸乳

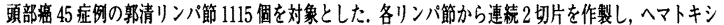
リン・エオジン (HE) 染色と抗サイトケラチン 7.8抗体を用いた免疫染色とを行った. 唈染色を用 いた組縓検索では指摘されず，免疫染色により初めて検出されるリンパ節檕移」をリンパ節微小転移

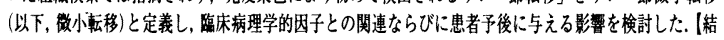
果微小転移は11例（24\%）において21 個のリンパ節に陽性であった，微小転移は，HE 染色で検出 可能な overt 転移陽性例 $(\mathrm{P}=0.017) ， 2$ 群以上の遠隔リンパ節 overt 転移陽性例に多かった $(\mathrm{P}=0.003)$. 致小転移淂性例（累皘 5 年生存率 $20 \%$ ）は，陰性例（同 76\%）に比し，有意に予後不良であった（P=

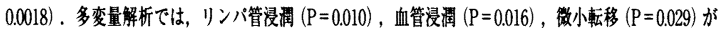

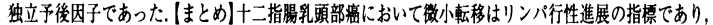
独立した强い子後因子である。微小転移陽性例には手術後に補助化学寮法を考虑すべきである。

PPB-3-215十二指腸乳頭部癌局所再発例の検討

飯澤 綮, 桜井直樹, 山内淳一郎, 須藤 剛, 林 洋毅, 岡上能斗竜, 武田真一, 渋間 久, 菊地 惊, 池田栄一 (山形県立中央病院外科)

十二指腸乳䫓部㽽 (以下本症) 切除例の局所再発をきたす要因と対策を㭘討.【対象】本症 36 例中の局所再発 5 例 (後述)。【結果】 36 例中再発は 15 例。第 1 再発部位は, 肝 5, \# 163 , 洋周囲

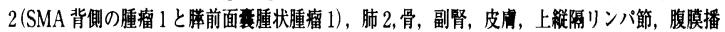
種が各 1 の計 17 病変 (2 例重複)。 \# 16 再発 3 例と蓄周囲再発 2 例の計 5 例を局所再発とした 36 例中 18 例に\# 16 郭清を施行. 局所再発 5 例は全て\#16 垶清非施行だった. 局所再発例の肉

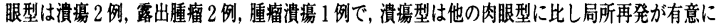
多かった. 潰燩型以外の 3 例の最大径は全例 $4.5 \mathrm{~cm}$ で, 局所再発のない同型 27 例の平均 $2.0 \mathrm{~cm}$ と有意差を認めた。病理組蟣学的にはly, pN, pPancで局所再発のない症例と有意差を認めた。 pPanc は他形式の再発 10 例と比较しても有意差を認めた. [考察・結語]ly や pN, pPanc は局所 再発例に高度たが，正確な術前診断は容易ではない，一方肉眼型や最大径は判定可能である，\# 16 垶清は controversial だが, \#16 郭清例に局所再発がないことより, 潰瘍型の症例や腫堭径の 大きな症例は，\#16 郭清を行って局所再発のリスクを減らせる可能性があると思われた。

PPB-3-216十二指腸乳頭部癌に対する縮小手術への模索 林谷康生, 村上義昭, 横山雄二郎, 佐々木秀, 森藤雅彦, 末田泰二郎 (広島大学大学院病態制御医科学外科)

目的：十二指腸乳頭部㾴は予後も比較的良好で内視鏡切除など試みられている が，その適応は超音波内視鏡 (EUS)による診断に委ねられている，EUSによる 羘十二指腸進展度診断の検討と予後規定因子から縮小手術への可能性を検討し た. 対象・方法：対象は 1981 年から 2003 年までの 35 例でEUSによる進展度 診断と病理組織学的深達度の比較, 各因子による 5 年生存率の比較を行った. 結 果・考察：膟十二指腸浸潤の正診率は 70\% で overdiagnosis の傾向にあったが 過小評価した 1 例を認めた. 5 年生存率の検討では stage 2 は stagelより低く， pancla までの症例は $91 \%$ で panclb 以上より高く, du0,1 は $95 \%$ で du 2,3 よ り高かった $(\mathrm{p}<0.01)$.リンパ節転移を認めた症例は $33 \%$ で認めなかった症例よ り低かった $(\mathrm{p}<0.05)$ ．深達度 $\mathrm{m}$ は $100 \%$ で panc0, du0,1ではリンパ節転移を

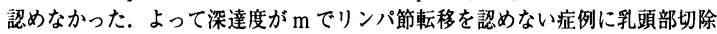
が可能と考えられるが，術前の䐙十二指腸浸潤の正確な診断は現時点では不十 分で全胃幽門輪温存荤頭十二指腸切除術が罗当な術式であると考えられた。 
PPB-3-217Vater 乳頭部癌に対する術中照射療法の意義 森谷敏幸，平井一郎，水谷雅臣，鈴木明彦，神賀正博，布施 明， 木村 理

(山形大学第 1 外科)

【目的】Vater 乳頭部癌での術中照射療法 (IORT) の有用性を検討した. 【対象と方 法】1977 年から 2003 年 12 月まで山形大学第一外科で根治切除 (勝頭十二指晹切除 術）を施行したVater 乳頭部癌 36 例を対象とした。手術群 28 例・IORT 併用群 8 例に分類し, 生存率・術後合併症・再発形式に関して両群を後乃向きに比較検討し た.【結果】背景因子 (年齡, 性別, 腫瑝の進行度) は両群間で差はなかった. 術後 合併症は滕液瘦が手術群で $3 / 28$ 例 $(11 \%) \cdot$ 手術+IORT 群で $1 / 8$ 例（16\%）(以下

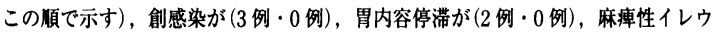
スが $(0$ 例・ 1 例 $)$ ，下湅が $(0$ 例・ 1 例 $)$ で差はなかった。再発形式は肝転移 (4 例 $\cdot 2$ 例 $)$ ，局所再発 $(1$ 例・ 0 例 $)$ ，骨転移 ( 1 例・ 0 例) であった. 5 年生存率は手 術群 $64 \%$ ・手術 +IORT 群 40\% (p=0.49) で有意差がなかった. [考察とまとめ】根 治切除可能な Vater 乳頭部癌に対して IORT の有効性は低いが, 合併症は少なく安 全であるため，適応症例を選択していけば有効である可能性が示唆された.

PPB-3-218 十二指腸乳頭部癌に対する病理組織学的検討と外科治療 の評価

塩崎滋弘, 原野雅生, 佐々木寛, 青木秀樹, 小野田正, 大野 聡, 相垣健二，小林直広，二宮基樹，高倉範尚

(広島市立広島市民病院外科)

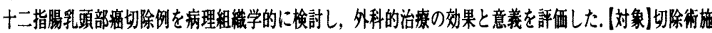

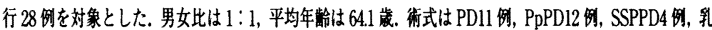

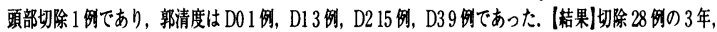

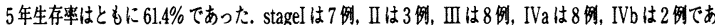

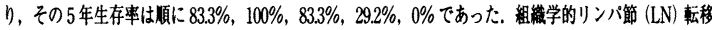
は陽性 11 例，陰性が 16 例，不明 1 例であり，その5年生存事は淂性 $38.1 \%$ ，陰性 $71.8 \%$ と陰性例で予後

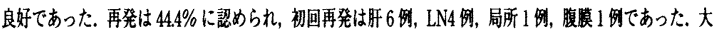

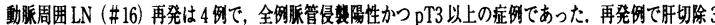
例，LN切除1例を施行しこれらは短期に再発したが，\#16再発例の中に放射線治㞠，2度の脚切除， 壁切除で再発後 3 年以上の生存例も認めた. [考察] 乳頭周囲進展を認める症例は\#16 郭清を含めた切除 が必要となる. 再発部に対する切除については今のところその意義が十分にあるとはいえない。

\section{PPB-3-219 十二指腸乳頭部癌の外科治療の問題点}

万本 潤, 伊藤 豊, 植田利貞, 原口義座

（国立病院東京災害医療センター外科）

【目的】十二指腸乳頭部癌の進展様式と再発形式から手術術式の反省点と 課題について検討.【対象】組織学的検索のなされた 54 例を対象とした. 術 式は, PpPD14 例, 幽門部切除術+䐙頭十二指腸切除術 (PD) 40 例を施行. 【成績】術後成績は 5 生率が $63.9 \%$ であった. 5 生率の比較では, リンパ節 転移陰性例 (n-) のうち ly 因子陽性例 $(50 \%) ， \mathrm{v}$ 因子陽性例 $(0 \%)$ はly 因子陰性例 $(81 \%) ， \mathrm{v}$ 因子陰性例 $(80 \%)$ に対し子後不良であった $(\mathrm{p}<$ 0.05 )。術後成績は panc0 が $83 \%$, panc1 が $57 \%$, panc2 以上は 5 生例を認 めなかった. 再発死亡例は 13 例認め原因は, 腹膜再発 5 例, 肝転移 9 例, 骨転移 1 例, 肺転移 1 例, 後腹膜再発 1 例.【結論】自験例では $70 \%$ がリン パ節転移陰性であり, $\mathrm{t}$ 因子が予後を左右していた. $\mathrm{v}$ 因子の予後への影慗 は少なくなく，悪性度の評価に寄与するものと考えられた． 2 群リンパ節 郭清 PDにより，局所再発の予防は期待しうると考えられた，晹間膜動脈 神経叢右側の郭清は大半の症例で省略できるものと考えられた。

\section{PPB-3-220 十二指腸乳頭部癌切除例の検討}

太田茂安, 鈴木昌八, 坂口孝宣, 稲葉圭介, 東 正樹, 神藤 修,

今野弘之, 中村 達

（浜松医科大学第 2 外科）

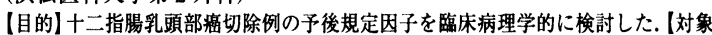
と方法】当科で切除術を行った十二指腸乳頭部賷 26 例を対象にLogrank testによ る単変量解析を行った. (成績JPDを 16 例, PPPDを 9 例, TPを 1 例に施行した. 胆道瘦取扱い规約による早期癌は 10 例であり, du (+) 16 例, panc (+) 13 例で あった.リンパ節転移は $\mathrm{n} 0$ が 15 例， $\mathrm{n} 1$ が 7 例， n2 以上が 4 例であった. $1 \mathrm{y}, \mathrm{v}$, pn の陽性例は各々 $14,6,3$ 例であった. 進行度は stageI が 8 例, II が 12 例, III が 2 例, IV が 4 例であった. 術死 1 例および消息不明の 2 例を除いた 23 例の 5 年生存率は $81.3 \%$ であった. 術式, 肉眼型, 腫湟径,リンパ節郭清度, 組織型, panc, ly, v, pn, n, t, stage の各因子での検討では, pancのみが有意な予後因子であっ た. panc (-) 13 例の 5 年生存率は $100 \%$ であったが, panc (+) 10 例では $56.3 \%$ と有意に予後不良であった.【結語】橧䐵漫潤陽性例の予後は不良であり，外科的切 除のみでなく化学療法などの集学的治療を考慮する必要があると考えられた。
PPB-3-221 当科における十二指腸乳頭部船に対する䐙頭十二指腸切 除術の治療成縝

大塚隆生，北原賢二，松山 悟，下西智德，中房祐司，宮崎耕治 (佐賀大学一般・消化器外科)

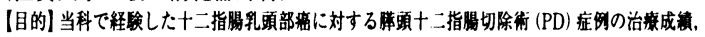
予後规定因子について检討した（方法】1985 年 2000年に当科て根治的PDを施行した20 田

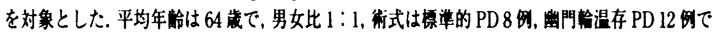

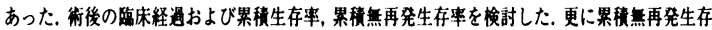

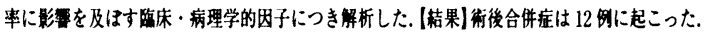

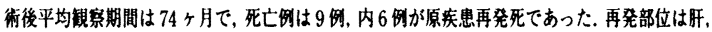

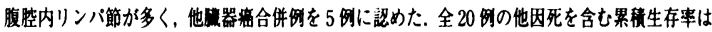
5 年 $52 \%, 10$ 年 $36 \%$ で，累稜焦再発生存事は 5 年 $47 \%, 10$ 年 $36 \%$ であった。烸床・病理学的

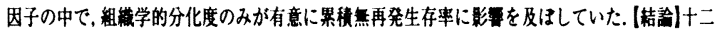

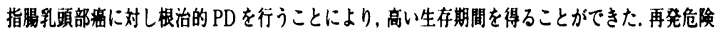

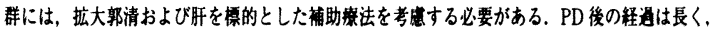

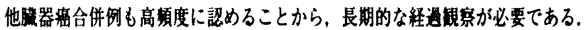

PPB-3-222 十二指晹乳頭部癌の外科治療成績からみた問題点と治療 のあり方 吉田宗紀，坂本友見子，星野弘樹，鹿取正道，島田 新，古田一德， 高橋 媇, 佐藤光史, 渡㞂昌彦

(北里大学外科)

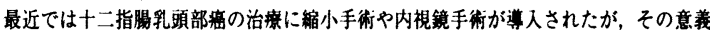
は未だ明らかではない. 自検例を調べ，本症の外科治緳の問面点と今後のあり方につい

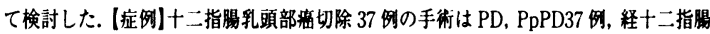
的乳頭部切除 1例であった. (結果) 1113 例， $\mathrm{t} 217$ 例， $\mathrm{t} 37$ 例であった.リンバ節転移

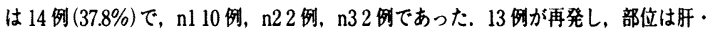
肺 13 例, 局所 1 例であった. 後者は切除断端が陰性の局所切除であるが, lyl でリンバ 管からの再発が示唆された. 予後因子として pancla と $1 \mathrm{~b}, \mathrm{n} 1$ と $\mathrm{n} 2$ の間に有意差を記 めた. 【考案】 tlでもリンパ節転移 $(\mathrm{nl})$ が見られた. stage I $(\mathrm{tl}, \mathrm{n} 0)$ で街後の肝・肺 再発をみた. 以上より，根治的切除を得るには確実な病変の切除と 2 群までリンパ節郭 清が不可欠で,我々はPpPD を基本術式と考えている.絠小手術や内視鏡手術の導入に は確実な術前診断もと, 今後のさらなる慎重な検討が必要と思われる.

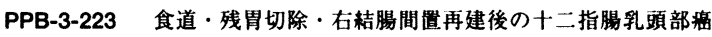
に対する羘頭十二指晹切除術の1例 大柣恭子"，永野靖彦"，五来克也"，松尾意“"，国䗁主税"， 池 秀之", 今田钽夫", 䦕户 使”, 鴄田 紜"

(横浜市立大学消化器病センター", 横浜市立大学第 2 外科 ${ }^{2 \prime}$ )

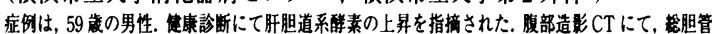

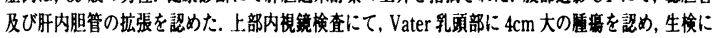

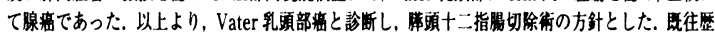

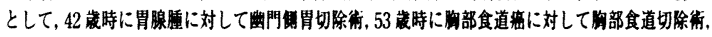

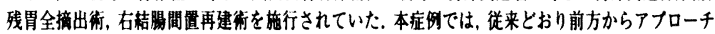

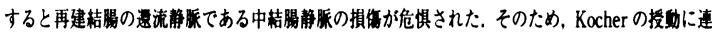

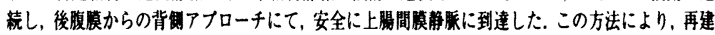

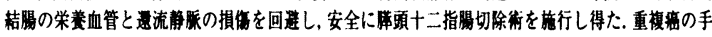

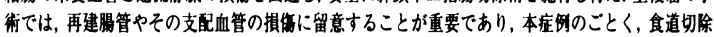

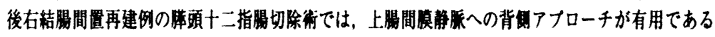

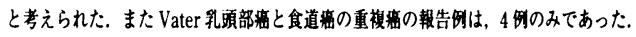

PPB-3-224 肝萁胞の增大によって閉塞性黄㾝をきたした1例 野田純代"，越川克已"，間瀬隆弘"，鈴木夏生"，田上鏡一郎", 山下克也

(厚生連渥美病院外科", Auckland city hospital ${ }^{2 \prime}$ )

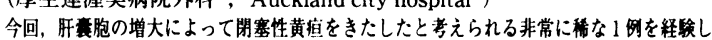
たので，若干の文献的考察を加えて報告する。 [症例] 77 藏，男性，平成 15 年 9 月 10 日に 発熱と右季助部庯を主訴に当院受診. 精査にて無石性胆重炎と診断され入院した。訮には

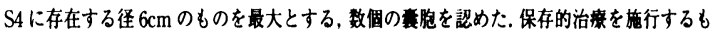
症状軽娍せず，炎症反応の上䄯を認めたため9月12日，PTGBDを施行した．その後腹庯 および発熱，炎症反応は怪娍したが，次第に胆道系醉素の上界，肝内胆管の㹡張をきたし 閉塞性黄疸が出現したため 9 月 30 日, B3より PTBDを妳行した。造影検査にては肝門部

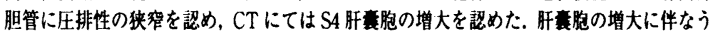

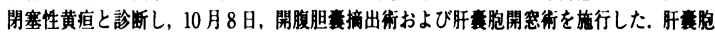
内容は淡黄色透明であった．毫胞壁は肥厚しており，術後病理にて炎症性緗胞の浸洞を認 めた. 術後経通は良好で術後21 日目にPTBD抜去し，退院となった. (考察)肝薹胞の增大 は，術前㨂入したPTGBD あるいは胆毫からの炎症の波及に伴なうものと考えられた。 
PPB-3-225演題取りトげ

PPB-3-226 総胆管壁内衰胞の 1 例

内倉敬一郎"，金子公"，青木 大"，三枝伸“"，福元俊孝"，

爱甲 孝?

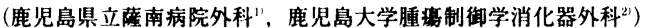

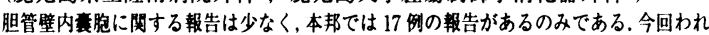
われは、三管合流部，並びに下部胆管に生じた壁内蒙胞の1例を経験したので報告する。

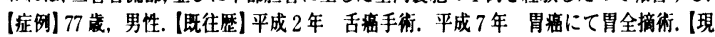
病歴!平成 15 年 7 月 肝機能障害認めCT, US, MRCP 施行し胆喜結石を認めた。

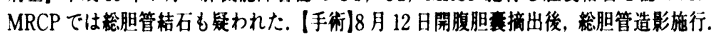

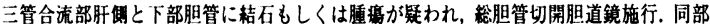

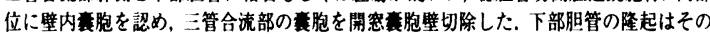
ままに, T tubeドレナージ術施。(病理組織学的検査)開空した壁は一層の円柱上皮より

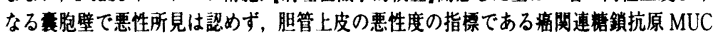

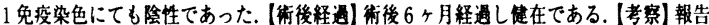

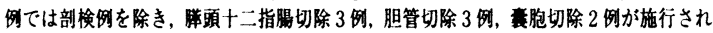
ている，今後の経通短察を要するが，本症例のような治暴法も選択可能と思われる。

PPB-3-227 肝外胆管共胞腺腫の一例

楖㛢利行, 長田真二, 今井寿, 天岡 望, 杉山保幸, 安達洋咗 (岐皇大学第 2 外科)

75 紫男性. 柽度の発熟を認め，近医を受診。血液梌查にて肝機能異常を認め，面像上，

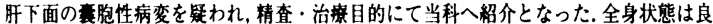

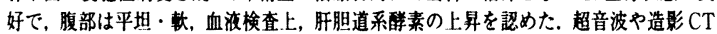

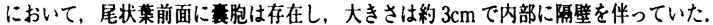

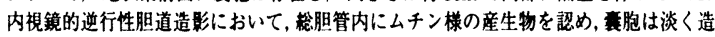
影され左肝管との交通が考えられた，胆汁中に悪性細胞は認めなかった，腹部血管造影

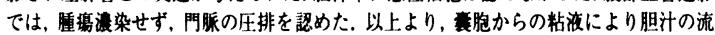
出障害をきたしたものと考元，本人および家人の希望もあり手術を施行した.術中所見 上, 费胞は左肝外胆管との交通があり，周囲への浸洞も認めず，售胞摘出を施行した。 術中迅速病理組满検查では，交通部には粘液産生細胞や悪性細胞を認めなかった。衰胞

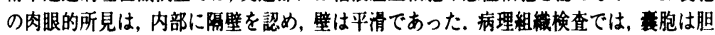

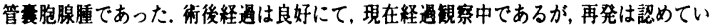

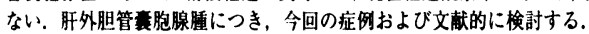

PPB-3-228 胆摘術後に生じた amputation neuroma による総肝管狭 窄の 1 手術例

日下部将史"，上田和光"，只野愁介"，中村亮太"，藤澤正宏"，

井上陽介"，加藤昌弘"，佐藤宗勝"，奥村 秢"，下釜達朗"

(日立製作所日立総合病院外科"，白立製作所日立総合病院病理科 ${ }^{21}$ )

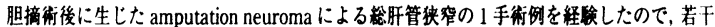

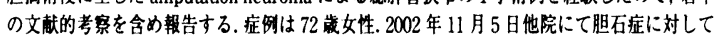

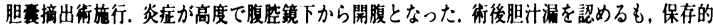
に軽快し 2002 年 12 月 26 日退院. その後CTにて肝内胆管の拡張を認め，黄疸の寬解・增

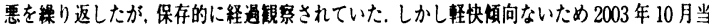

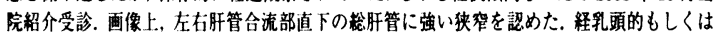
PTCDからのフジー・ステントは股に良性胆管狭窄には暗応がなく，本人の希望もあり

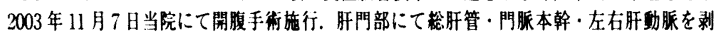

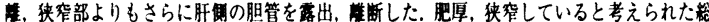

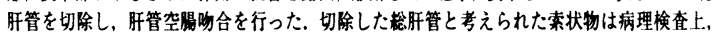

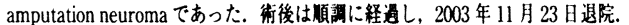

PPB-3-229 胆管癌との鑑別が困難であった Hepatic peribiliary cysts の一例

武田 茂, 古谷卓三, 熊谷和美, 佐藤路子, 岡田敏正, 矢原 昇, 林 弘人, 村上卓夫

(国立下関病院外科)

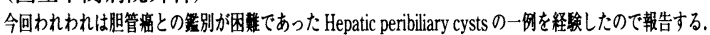

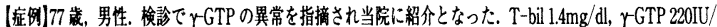

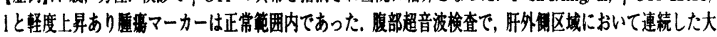

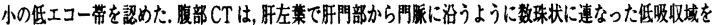

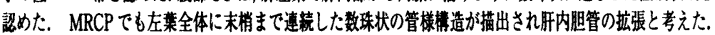

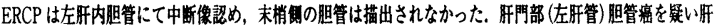

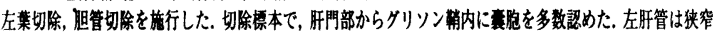

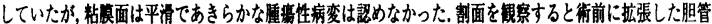

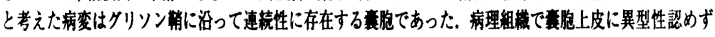
Hepatic peribiliary cysts $と$ 診断した.

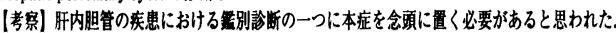

PPB-3-230 胆管炎を併発し術前に診断困難であった肝内胆管の著明 な数珠状拡張を呈したCaroli 病の一例

大久保博世, 星野弘樹, 坂本友見子, 鹿取正道, 島田 謙, 古田一德, 高橋 媇, 吉田宗紀, 佐藤光史, 渡透昌彦 (北里大学外科)

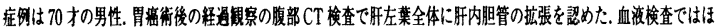

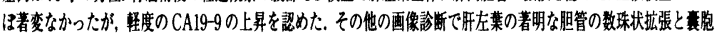

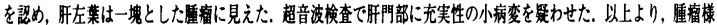

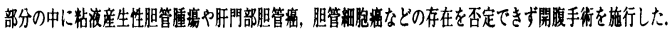

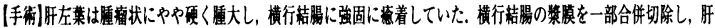

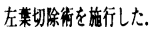

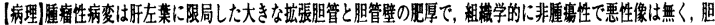

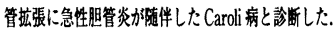

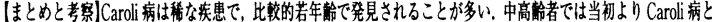

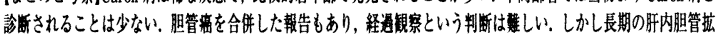

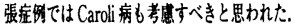

